\title{
High-Level Waste System Process Interface Description
}

by

P. D. d'Entremont

Westinghouse Savannah River Company

Savannah River Site

Aiken, South Carolina 29808

This paper was prepared in connection with work done under the above contract number with the U.S. Department of Energy. By acceptance of this paper, the publisher and/or recipient acknowledges the U.S. Government's right to retain a nonexclusive, royalty-free license in and to any copyright covering this paper, along with the right to reproduce and to authorize others to reproduce all or part of the copyrighted paper. 


\section{DISCLAIMER}

This report was prepared as an account of work sponsored by an agency of the United States Government. Neither the United States Government nor any agency thereof, nor any of their employees, makes any warranty, express or implied, or assumes any legal liability or responsibility for the accuracy, completeness, or usefulness of any information, apparatus, product, or process disclosed, or represents that its use would not infringe privately owned rights. Reference herein to any specific commercial product, process, or service by trade name, trademark, manufacturer, or otherwise does not necessarily constitute or imply its endorsement, recommendation, or favoring by the United States Government or any agency thereof. The views and opinions of authors expressed herein do not necessarily state or reflect those of the United States Government or any agency thereof.

This report has been reproduced directly from the best available copy.

Available to DOE and DOE contractors from the Office of Scientific and Technical Information, P.O. Box 62, Oak Ridge, TN 37831; prices available from (615) 576-8401.

Available to the public from the National Technical Information Service, U.S. Department of Commerce; 5285 Port Royal Road, Springfield, VA 22161. 


\section{DISCLAIMER}

\section{Portions of this document may be illegible in electronic image products. Images are produced from the best available original document.}


WSRC-TR-94-0442

Rev. 1

March 1995

\section{HIGH-LEVEL WASTE SYSTEM PROCESS INTERFACE DESCRIPTION}

Functions and Requirements of the High-Level Waste Process (U)

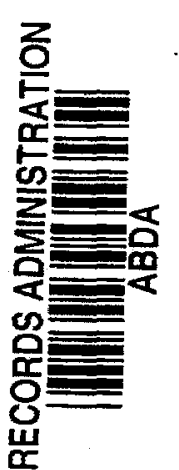
P. D. d'Entremont
R. A. Jacobs, SRTC
J. R. Fowler
D. F. Brown
D. J. McCabe, SRTC
D. D. Walker, SRTC
J. M. Gillam

Westinghouse Savannah River Company High-Level Waste Management Division Aiken, SC 29808

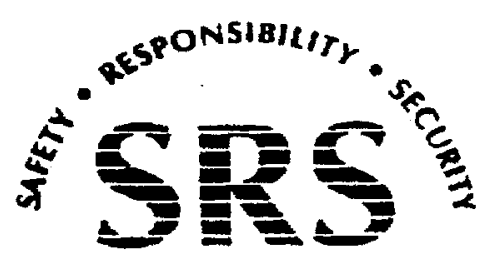


WSRC-TR-94-0442

REVISION: 1

KEYWORDS:

Tank Farm, Chemicals, DWPF, ITP, ETF, ESP, Functional Description, Requirements, Interfaces

RETENTION: PERMANENT

CLASSIFICATION: U

Does ngt contain UCNI

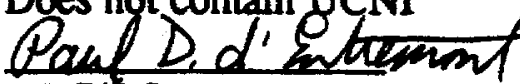

ADC/RO

\section{HIGH-LEVEL WASTE SYSTEM PROCESS INTERFACE DESCRIPTION \\ Functions and Requirements of the High-Level Waste Process (U)}
P. D. d'Entremont
R. A. Jacobs, SRTC
J. R. Fowler
D. F. Brown
D. J. McCabe, SRTC
D. D. Walker, SRTC
J. M. Gillam

Issued: 31 March 1995

Apaul D.d'Etrenal

P. D. d'Entremont, Author, HIWE

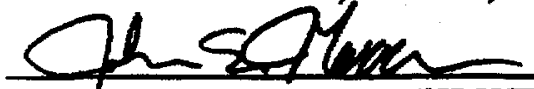

J. E. Marra, Manager, HLWE Support

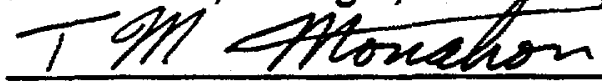

T. M. Monahon, Manager, HLWE

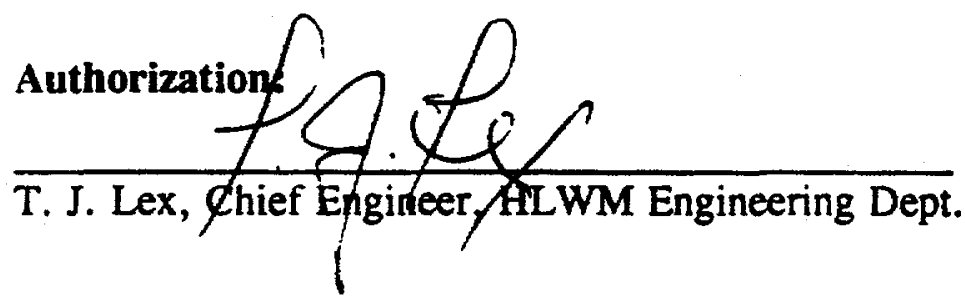

Date: 28 Mar 95

Date: $3 / 28 / 95$

Date: $3 / 28 / 95$

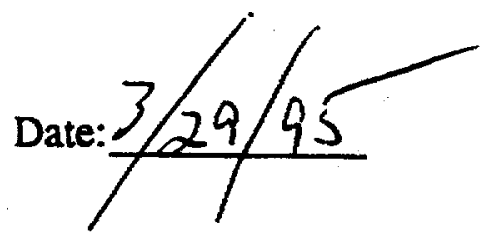




\section{Table of Contents}

Page No.

1. SUMMARY

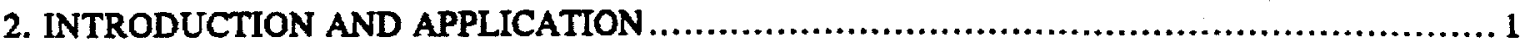

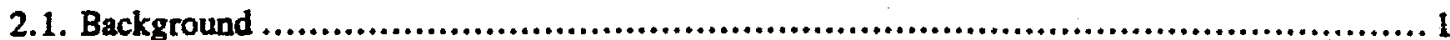

2.2. Description and Purpose of the Process Interface Description .................................. 3

2.3. Changes to Process Interface Description ..................................................... 4

3. HIGH-LEVEL WASTE SYSTEM FUNCTIONS AND HOW THEY ARE ACCOMPLISHED.......5

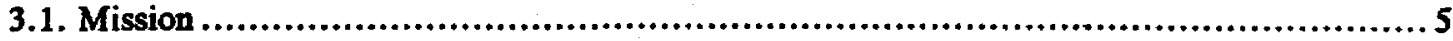

3.2. Function Definitions............................................................................ 5

3.3. Allocation of HLW System Functions to HLW Processes ....................................16

3.4. Defining the HLW Processes and Interfaces..................................................17

3.4.1. Relationship of the Process Interface Description

and HLW Process Technical Baselines..........................................................18

3.4.2. Definition of an Interface .............................................................19

3.4.3. Application of the Interface Concept................................................20

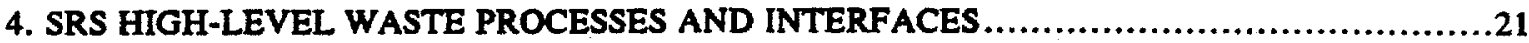

4.1. Overall High-Level Waste Process Description ............................................21

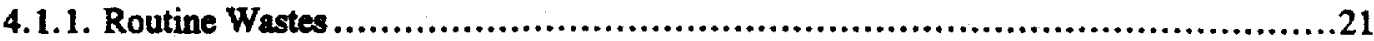

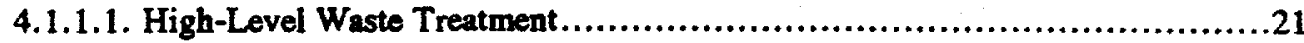

4.1.1.2. Low-Level Aqueous Waste Treatment.........................................24

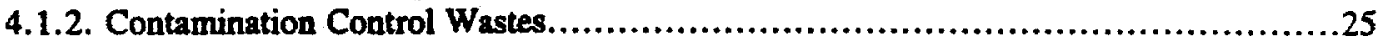

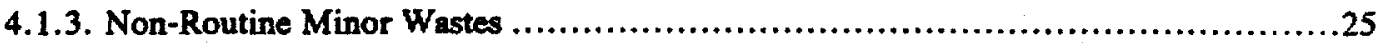

4.1.4. Unusual and Unique Wastes.......................................................26

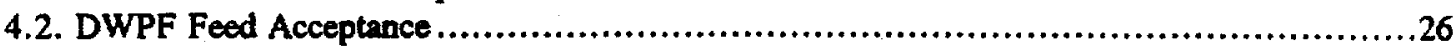

4.2.1. HLW Material Evaluation Board ...................................................27

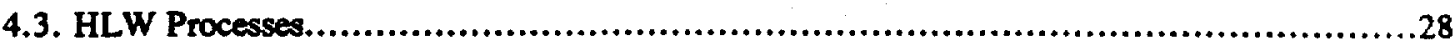

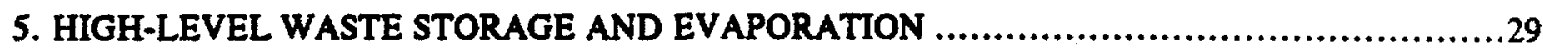

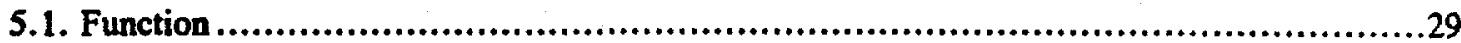

5.2. Description of the Storage and Evaporation Process ........................................29

5.2.1. Receipt, Storage, and Aging of Waste...............................................32

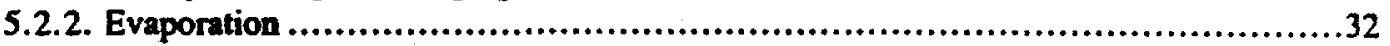

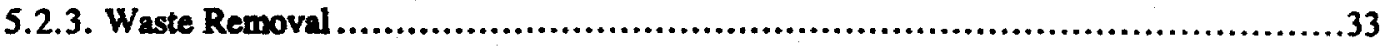

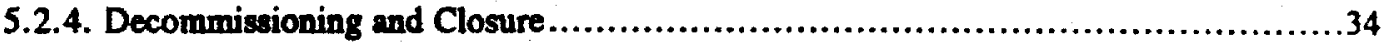

5.3. Influent Streams and Key Process Variables.................................................

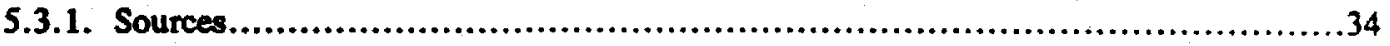

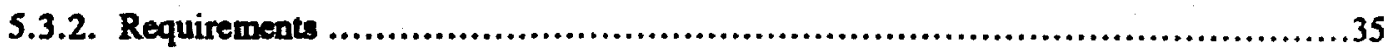

5.3.2.1. Requirements for Corrosion Prevention .....................................36

5.3.2.2. Requirements for Prevention of Accumulation of Flammable and Explosive

Components..........................................................................37

5.3.2.3. Cs-137 Concentration in Waste Transferred to Type IV Tanks....................37

5.3.2.4. Requirements for Regulatory Compliance..................................... 38

5.3.2.5. Requirements for Criticality Safety .......................................38

5.3.2.6. Requirements for SAR Source Term Comparison ...............................38

5.3.2.7. Requirements to Satisfy ETF Feed Bases ......................................39

5.3.2.8. Requirements to Satisfy Saltstone Waste Acceptance Criteria ....................39

5.3.2.9. Requirements to Satisfy DWPF Glass Feed Design Basis .......................39

5.3.2.10. Requirements to Satisfy ITP SAR addendum Basis ..........................39

5.4. Effluent Streams and Key Process Controls ................................................40 


\section{Table of Contents}

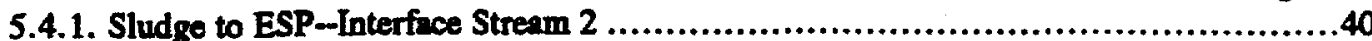

5.4.2. Salt Solution to ITP-Interface Stream 5 ..........................................40

5.4.3. Evaporator overheads-Interface Stream 13 .........................................41

5.4.4. Storm Water Runoff (Clean and Diverted)-Interface Stream 17 ......................41

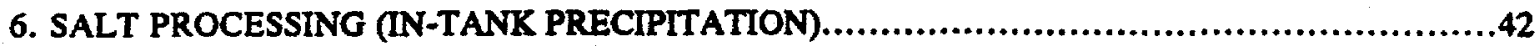

6.1. Function .......................................................................................42

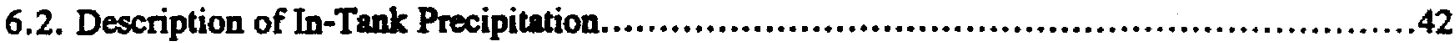

6.2.1. Decontamination and Concentration Process ..........................................44

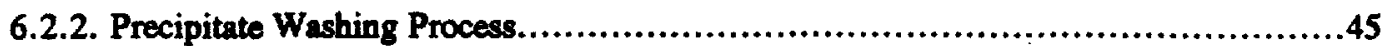

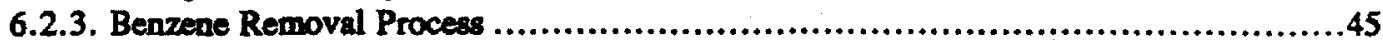

6.3. Influent Streams and Key Process Variables...............................................45

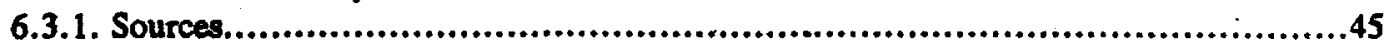

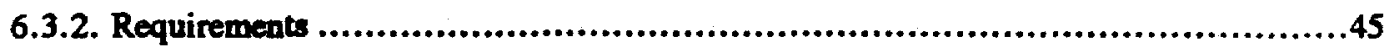

6.3.3. Requirements for Corrosion Prevention .............................................46

6.3.4. Tank 48H Influent Composition Safety Requirements ................................46

6.3.5. Tank 22H Feed Requirements--Interface Stream 8 ....................................46

6.3.6. Tanks 48H and 49H Criticality Safety Requirements ...............................46

6.3.7. Requirements to Satisfy Saltstone Feed Requirements-Interface Streams 5 and $15 \ldots . .46$

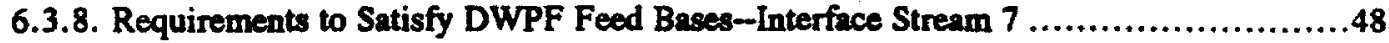

6.3.9. Raw Materials .........................................................................48

6.4. Effluent Streams and Key Process Controls ...............................................49

6.4.1. Decontaminated Supernate to Saltstone--Interface Stream 6.........................49

6.4.2. Precipitate to Late Wash-Interface Stream 7 ..........................................49

6.4.3. Diverted Storm Water to ETF--Interface Stream 17 ...................................49

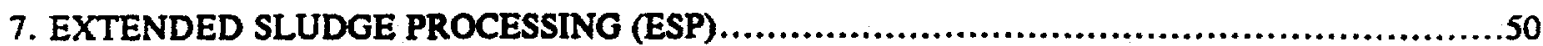

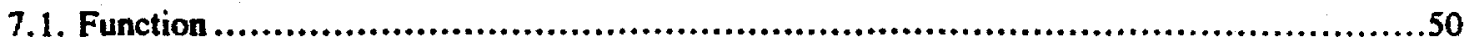

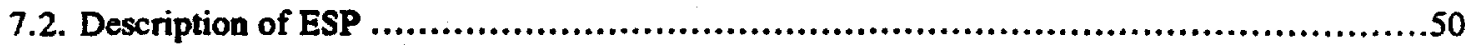

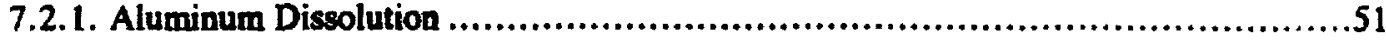

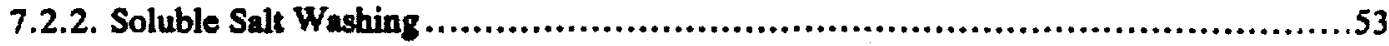

7.3. Effluent Streams and Key Process Controls ...............................................53

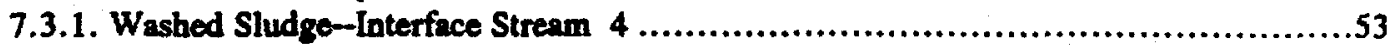

7.3.2. Decanted Supernate-Interface Stream 3 ............................................54

7.3.2.1. Disposition Alternatives.......................................................55

7.3.2.2. Corrosion Inhibitor Content ................................................55

7.3.2.3. Additional Limits for Type IV Tanks.......................................55

7.3.3. Storm Water Runoff (Clean and Diverted)--Interface Stream 18 ....................55

7.4. Influent Streams and Key Process Variables..............................................55

7.4.1. Untreated Sludge-Interface Stream 2 ............................................55

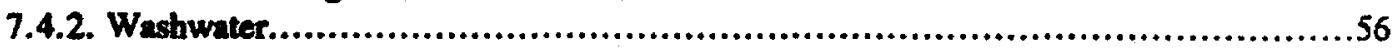

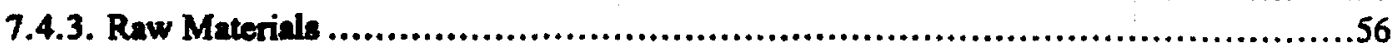

8. DEFENSE WASTE PROCESSING FACILITY (DWPF) Includes Late Wash Facility (LWF) .......57

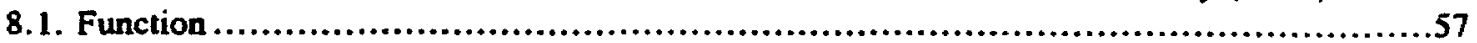

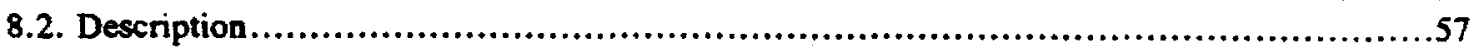

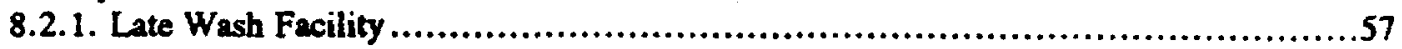

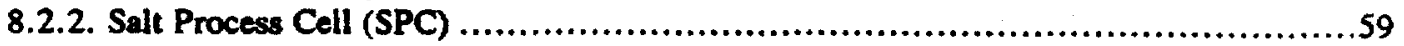

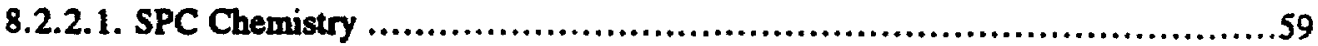

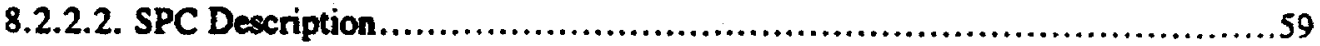

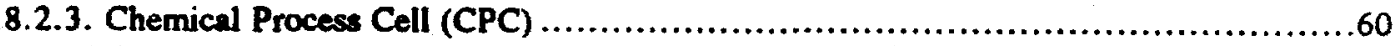

8.2.3.1. CPC Description ..........................................................60 


\section{Table of Contents}

8.2.3.2. Product Composition Control ...............................................61

8.2.4. Melt Cell ...............................................................................61

8.2.5. Canister Closure and Decontamination ............................................62

8.2.6. Process Air Emissions............................................................62

8.3. Effluent Streams and Key Process Controls ...............................................63

8.3.1. The Canistered Waste Form--Interface Stream 9 ....................................63

8.3.1.1. Canister Requirements.........................................................63

8.3.1.2. Cenister Integrity/Cleanliness ...............................................64

8.3.1.3. The Borosilicate Glass.........................................................664

8.3.2. DWPF Aqueous Recycle Streams ...............................................64

8.3.2.1. LWF Spent Wash Water--Interface Stream 8 ................................64

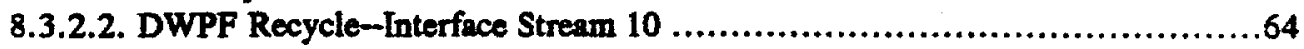

8.3.3. Recovered Otganic-Interface Stream 11 ..........................................65

8.3.4. Recovered Mercury-Interface Stream 12 ........................................65

8.4. Influent Streams and Key Process Variables...............................................65

8.4.1. High-Level Waste Feed Streams.....................................................65

8.4.1.1. Precipitate Feed to the LWF-.Interface Stream $7 \ldots \ldots \ldots \ldots \ldots \ldots \ldots \ldots \ldots \ldots 65$

8.4.1.2. Sludge Feed-Interface Stream 4 ..........................................65

8.4.1.3. Requirements for High-Level Waste Feed Streams ............................66

8.4.2. Raw Materials .................................................................67

9. WASTEWATER TREATMENT-THE EFFLUENT TREATMENT FACILITY ..................69

9.1. Function ...................................................................................69

9.2. Description of the ETF Process...........................................................69

9.2.1. Process Sewer and Treatment Plant .................................................69

9.2.2. Diverted Water Basins............................................................. 71

9.3. Influent Streams and Key Process Variables...............................................71

9.3.1. Evaporator Overheads and Other Low Level Streams-Interface Stream 13 ...........71

9.3.2. Diverted Cooling Water and Diverted Storm Water--Interface Streams 17 and $18 \ldots \ldots .73$

9.3.3. Raw Materials and Lab Reagents..................................................73

9.3.4. Unusual and Unique Wastes.......................................................73

9.4. Effluent Streams and Key Process Controls ...............................................74

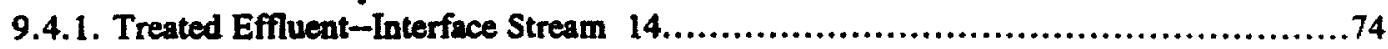

9.4.2. ETF Concentrate-Interface Stream 15 ............................................ 74

9.4.3. Clean Basin Water .............................................................. 74

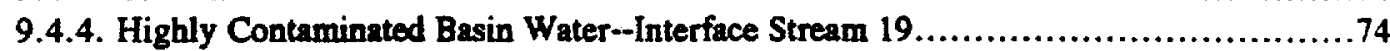

9.4.5. Highly Contaminated Evaporator Bottoms--Interface Stream $20 \ldots \ldots \ldots \ldots \ldots \ldots \ldots \ldots .75$

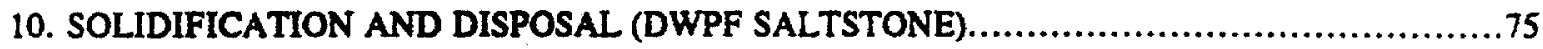

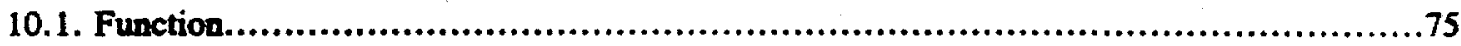

10.2. Description of the Saltstone Production and Disposal Process .............................75

10.2.1. Saltstone Production Facility " .................................................75

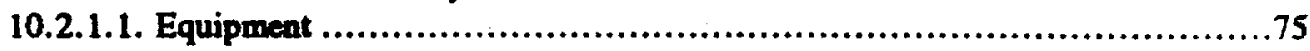

10.2.1.2. Waste Receipt ...........................................................77

10.2.1.3. Process ....................................................................77

10.2.2. Saltstone Disposal Facility ' ......................................................... 77

10.2.2.1. Disposal Operations Prior to Closure .....................................77

10.2.2.2. Site Closure.................................................................78

10.3. Influent Stream and Key Process Variables--Interface Stream 6 .............................78

10.4. Effluent Stream and Key Process Controls--Interface Stream $16 \ldots \ldots \ldots \ldots \ldots \ldots \ldots \ldots \ldots . \ldots . \ldots . \ldots \ldots$

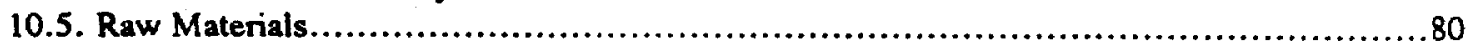


2

Hiph-Level Waste System Proces Interface Description

\section{Table of Contents}

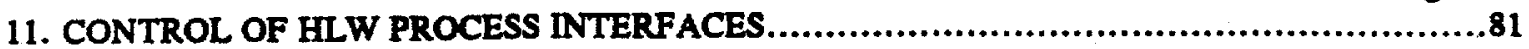

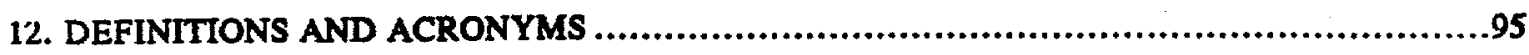

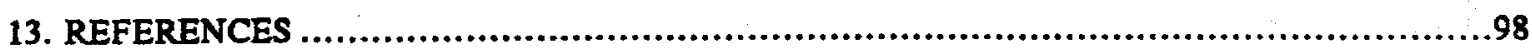




\section{SUMMARY}

The High-Leval Waste System is a set of six different processes interconnected by pipelines. These processes function as one large treatment plant that receives, stores, and treats high-level wastes from various generators at SRS and converts them into forms suitable for final disposal. The three major forms are borosilicate glass, which will be eventually disposed of in a Federal Repository, Saltstone to be buried on site, and treated water effluent that is released to the environment.

Processing of these wastes in a safe, effective, and environmentally sound manner is critical to accomplishing the HLW System's mission. Nine of the waste tanks have leaked in the past. Twentyfour of the tanks do not meet current regulatory standards. And all of the high-level wastes are prohibited from continued storage under EPA regulations.

The High-Level Waste (HLW) System Process Interface Description (PID) was created to promote effective integration of the six HLW Processes. The PID

- Describes the entire HLW System in terms of its overall mission and is a useful reference for understanding the operation of the system.

- Identifies the functions of the HLW system and how these functions are allocated to the six HLW processes

- Identifies a system of interface control documents that, taken together, control the interactions of all of the HLW Processes.

- Enhances communication among people managing the various HLW Processes. This will ensure that decisions about changes to HLW Processes that could have an effect on downstream processes are properly identified, communicated, and reviewed.

Thus, the PID is a key tool for ensuring that the HLW System accomplishes its mission in a safe, efficient, and environmentally sound manner.

\section{INTRODUCTION AND APPLICATION}

\subsection{Background}

The High-Level Waste System is a set of six different processes interconnected by pipelines:

1) High-Level Waste Storage and Evaporation (F- and H-area Tank Farms)

2) Salt Processing (In-Tank Precipitation)

3) Extended Sludge Processing

4) Vitrification (DWPF Late Wash, DWPF Pretreatment, and Vitrification)

5) Wastewater Treatment (Effluent Treatment Facility)

6) Solidification (DWPF Saltstone) 


\section{Figure 2-1: The High-Level Waste System}

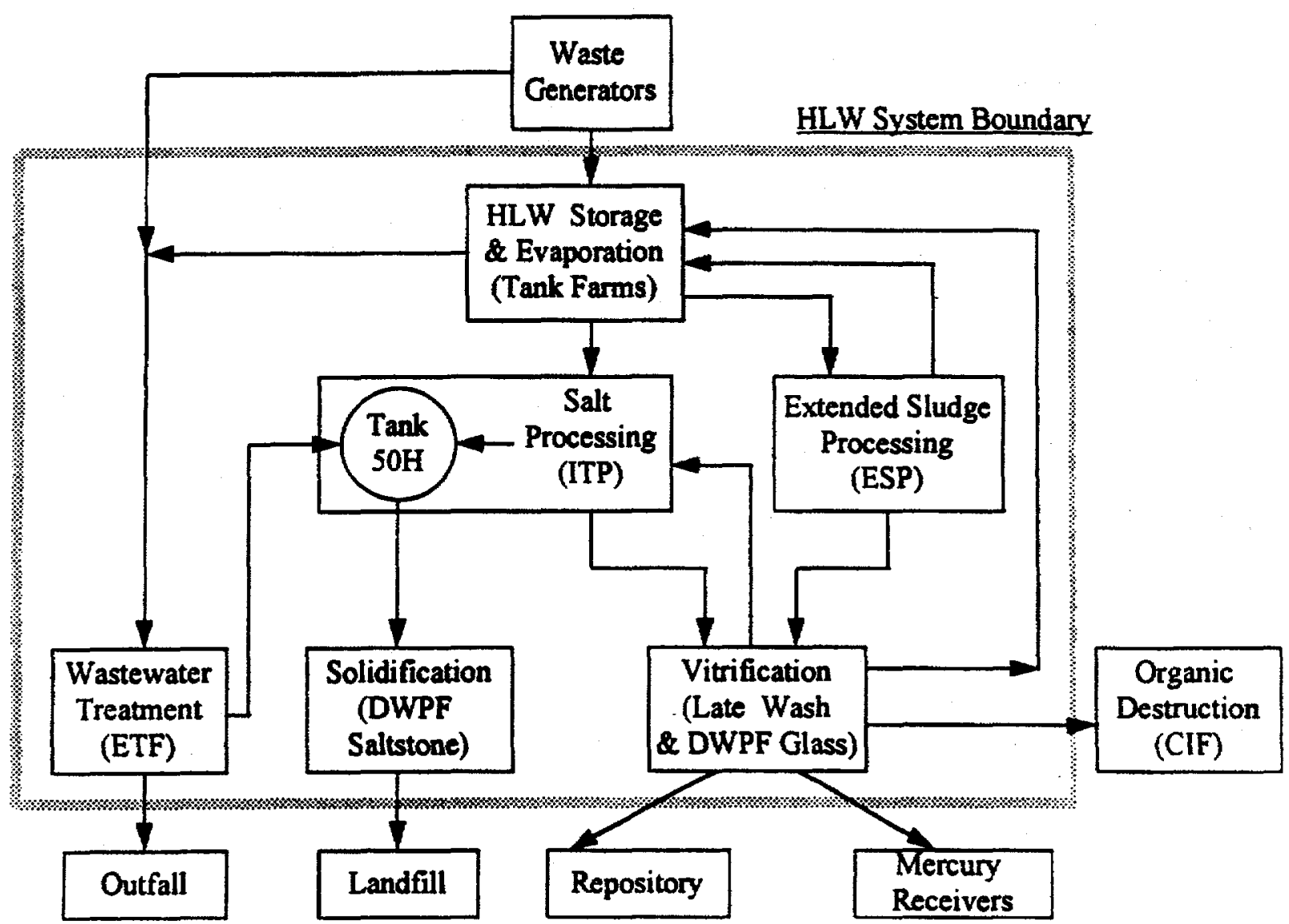

To a large extent, these processes function independently, and each accomplishes several of the functions of the HLW system. But taken together these six HLW Processes function as one large treatment plant that stores and treats high-level wastes (primarily from the F-and H-area Separations Processes) and converts them into forms suitable for final disposal, specifically glass, Saltstone, and decontaminated effluent from ETF.

Characterizing and controlling the composition of these wastes as they pass among the HLW Processes is essential to safe, effective, and environmentally sound operation of HLW Processes. HLW is a complex mixture of radionuclides, soluble salts, and insoluble sludges. Many of these components are hazardous to human health (e.8. plutonium) or can cause serious hazards if not properly managed. Many components can cause processing problems if present in inappropriate concentrations (e.g. high-levels of aluminum in the washed sludge could impact operation of the DWPF glass melter, greatly increasing the cost and time to process the waste). And the composition of each of the effluent streams-glass, Saltstone, and decontaminated water-is regulated by outside regulatory agencies. Thus, good coordination among the management of the HLW Processes is essential to ensure that the HLW System accomplishes its mission in a cost-effective menner.

However, good communication and coordination are difficult because of the size and organizational structure of the HLW System. Also, the facilities in the HLW system have been constnicted over a 40year period, and many are performing functions that are different from their originally intended function. For example, tank 48 was originally intended as a storage tank but is now being used as a reaction vessel. Another example is that the ITP process was originally intended to completely wash precipitate in 
preparation for vitrification in DWPF, but will now only perform the first phase of the wash (because the washing will be completed in the Late Wash Facility). Thus, a clear understanding of the functions and requirements of each process is needed to ensure that changes in one HLW Process don't cause unrecognized safety or processing problems in another HLW Process.

The PID was created as a result of this concern. The PID serves as a functions and requirements document in that it identifies the functions of HLW systems and the requirements for how each of these functions is accomplished within the existing HLW processes. However, since the facilities are already existing, the PID does not define the processes and requirements, as would happen in a traditional systems engineering approach (In a traditional approach, the functions and requirements would be defined first, and then the processes would be developed from those). Instead, the PID identifies the already existing processes and defines the functions and requirements of each, providing an overall technical basis for the HLW system. This provides a technical basis for decision making in the HLW System and for recognizing when process changes in one HLW Process might affect other processes.

\subsection{Description and Purpose of the Process Interface Description}

The PID describes

- The mission of the HLW System,

- The functions of the HLW system

- The six HLW Processes that comprise the HLW System, and

- The technical basis for the major interfaces among the HLW Processes, including the interface control documents at each interface. These interface control documents are included in the technical baseline for each HLW Process.

Before a change is made to a HLW Process, the change is reviewed to assess its impact on the PIDrelated interfaces for that Process. Thus, the PID is a key tool for assuring that changes to HLW Processes are consistent with the overall mission.

The objectives of the PID are as follows:

- Provides the basis for identifying and controlling HLW Process changes that could impact other processes.

- Identifies 1) the internal interfaces where wastes and other materials are being exchanged between HLW Processes and 2) external interfaces leading into or out of the HLW System.

- Identifies the basis for controlling each interface and how this control is documented.

- Complements each HLW Process's technical baseline and avoids unnecessary duplication of HLW Process's technical baselines.

- Promotes decision making at the appropriate organizational level. Decisions that affect only one HLW Process are outside the scope of the PID and can therefore be made at the HLW Process level; decisions with broader impact across the HLW System are inside the PID scope and must be made at an appropriately higher level. 


\subsection{Changes to Process Interface Description}

As with any living document, changes to the PID are expected as changes are needed in the HLW System. Changes will be controlled acconding to the System Integration Management Plan (SIMP), a HLWM division-level guidence document.

To ensure that changes in the HLW System are adequately reviewed, the SIMP incorporates the following provisions:

- The Engineering Manugement of each HLW Process is responsible for ensuring that changes within its HLW Process are properly reviewed to determine their potential for impact on the PID interface control documents. If the review determines that an interface control document or the PID itself may need to be changed, then the Engineering Management for the associated HLW Process is responsible for initiating review of the change at the division level.

- Changes to the PID will be reviewed and approved at the division level and will require review and approval by the management of all the HLW Processes.

- Additions of new process chemicals to a HLW Process, not anticipated by the PID, or significant changes in the planned quantities of existing process chemicals will be considered changes to the PID. Therefore, such changes must be reviewed at the division level and will require review and approval by the management of all the HLW Processes. Laboratory wastes and incidental quantities of chemicals are excludod from this provision.

- Laboratory wastes and incidental chemicals will be evaluated based on a minimal risk evaluation.

- Changes to external interface control documents (i.e. when one of the processes at the interface is outside the HLW System) will require review and approval by the management of that HLW Process and review at the division level. Management of the HLW Process is responsible for determining if the change could have an impact on other interfaces, and, if there is the potential for impact, those interface documents must be reviewed and revised, as necessary.

- Changes to internal interface control documents (i.e. when both processes are HLW Processes) must be reviewed and approved by the management of both affected processes and also at the division level. 


\section{HIGH-LEVEL WASTE SYSTEM FUNCTIONS AND HOW THEY ARE ACCOMPLISHED}

\subsection{Mission}

The mission of the HLW System is to receive and store SRS high-level wastes in a safe and environmentally sound manner, and to convert these wastes into forms suitable for final disposal. The planned forms are 1) borosilicate glass to be sent to a Federal Repository, 2) Saltstone to be disposed of on site, and 3) treated wastewater to be released to the environment. In addition, various effluents and other miscellaneous wastes are generated that must be managed. Also, the storage tanks and facilities used to process the high-level waste must be left in a state such that they can be decommissioned and closed in a cost-effective manner and in accordance with appropriate regulations and regulatory agreements.

Removal of the waste from the high-level waste tanks is needed to resolve several safety and regulatory concerns. Nine tanks at SRS have leaked observable quantities of waste from primary to secondary containment, and one of these tanks, Tank $16 \mathrm{H}$, leaked a few tens of gallons of waste to the environment in 1960. 'Two other tanks, Tank $19 \mathrm{H}$ and $20 \mathrm{H}$, have known penetrations above the liquid level, although no waste has been observed to leak through these penetrations. Tanks 1 through 24 do not meet EPA secondary containment standards for storage of hazardous waste, which were effective January 12 , $1987 .^{2}$

As a result of these concerns, removal of the wastes from tanks 1 through 24 is required by the Federal Facility Agreement for SRS among DOE, EPA, and SCDHEC. ${ }^{3}$ As part of the FFA process, DOE has committed to a schedule for removing the wastes from the tanks.

Furthermore, all of the high-level wastes in storage at SRS are Land Disposal Restricted wastes, which are prohibited from storage. Since the planned processing of these wastes will require considerable time and therefore continued storage of the waste, DOE has entered into a compliance agreement with the EPA. This compliance agreement requires processing of all the high-level waste at SRS according to a schedule negotiated between DOE and EPA.

\subsection{Function Definitions}

The functions of the SRS HLW System have recently been analyzed using a systems engineering methodology. For new projects, the systems engineering process, as defined by DOE Order 4700.1 is a sequence of activities that transforms an identified mission need into a description of system performance and a preferred system configuration.

However, since most of the components of the SRS HLW system are in the final stages of design, construction, or testing, it is not possible to perform a traditional systems engineering functional analysis. Consequently, a "reverse" systems engineering methodology was used to break down the components and processes of the SRS HLW-system. In the "reverse" systems engineering analysis an existing system (designed, constructed, or operated) is described in terms of the functions that must be performed by the collection of parts, components, or facilities that make up that system rather than by traditional organization structures and boundaries.

For the HLW system, this functional analysis begins with the mission of the system as described in the previous section. From this top-level statement, all essential functions that the system must perform are 
derived. These functions are simple statements of purpose and define what the system must do.

Function statements are by definition composed of an action verb and noun, and are usually singular in nature; that is, they describe one sctivity or process.

The functional breakdown to the fourth level for the SRS HLW system is schematically illustrated in the Table below. A brief description of each function is provided. For consistency, the numbering system is identical to that used in the High-Level Waste Management Technology Program Plan."

Function Description

1.0 Manage High-Level Waste

The mission of the HLW System is to receive and store SRS high-level wastes in a safe and environmentally sound manner, and to convert these wastes into forms suitable for final disposal. The major wasteforms are 1) borosilicate glass to be sent to a Federal Repository, 2) Saltstone to be disposed of on site, and 3) treated wastewater to be released to the environment. In addition, various effluents and other miscellaneous wastes are genented that must be managed. Also, the storage tanks and facilities used to process the high-level waste must be left in a state such that they can be decommissioned and closed in a cost-effective manner and in accordance with appropriate regulations and regulatory agreements.

$1.1 \quad$ Receive Waste

Receive neutralized liquid waste $(\mathrm{pH}>12$ ) and dilute effluents from waste generating orgunizations to support production missions and facility decontamination and decommissioning.

\subsubsection{Receive Routine Low-Heat Waste}

Receive neutralized liquid waste from normal processing operations associated with the F- and H-area Separations processes (with the exception of waste from the first cycle of solveat extraction), the Savannah River Technology Center, the actors Division, the Receiving Basin for Offside Fuel (RBOF), the Resin $R \mathbf{R}$..eration Facility (RRF), and recycle streams associated with the treatment and processing of existing waste storage in the HLW tanks (e.g., recycle from the Defense Waste Processing Facility).

\subsubsection{Ensure Waste Acceptance}

Ensure that any waste that is intended for transfer meets the waste acceptance criteria for routine low-heat waste.

1.1.1.2 Designate Receipt Tank

Decide which tank in each Tank Farm will receive the routine low-heat waste.

\subsubsection{Perform Transfer}

Pump the waste from the Separations Process to the Tank Farm using approved procedures.

\subsubsection{Close Material Balance}

Ensure that amount sent from the Separations Process matches that received in the Tank Farms and none is loss in transit. 
1.1.2

1.1.2.1

1.1.2.4

1.1.3

1.1.3.1

1.1.3.5

1.1 .4

\section{Receive High-Heat Waste}

Receive neutralized waste from the normal first cycle operations of the F- and H-area Sepantions Canyon solvent extraction processes.

\section{Ensure Waste Acceptance}

Ensure that any waste that is intended for transfer meets the waste acceptance criteria for high-heat waste.

\section{Designnte Receipt Tank}

Decide which tank in each Tank Farm will receive the high-heat waste.

Perform Transfer

Pump the waste from the Separations Process to the Tank Farm using approved procedures.

\section{Close Material Balance}

Ensure that amount sent from the Separations Process matches that received in the Tank Farms and none is loss in transit.

\section{Receive Special Wastes}

Receive waste generated as part of non-routine activities associated with a production process (e.g., water flush of processing vessels), special activities associated with routine process (e.g., use of special cleaning solutions), or one-time activities (e.g., facility decommissioning and closure). Typically the waste components change from batch to batch.

\section{Ensure Waste Acceptance}

Ensure that any special waste intended for transfer meets the waste acceptance criteria. For special wastes, this will usually involve special review and approval by HLW management.

\section{Designate Receipt Tank}

Decide which tunk in each Tank Farm will receive the routine special waste.

\section{Prepare Receipt Tank}

If necessary, prepare the receipt tank for the transfer. Special receipts will sometimes be received into tanks that do not normally receive wastes directly from generators. Occasionally special monitoring will be required. The type and amount of preparation will vary with different waste types, and some special wastes will need no preparation at all.

\section{Perform Transfer}

Pump the waste from the waste generator to the Tank Farm using approved procedures

\section{Close Material Balance}

Ensure that amount sent from the waste generator matches that received in the Tank Farms and none is loss in transit.

\section{Receive Nuclear Facility Liquid Effluents}

Receive dilute liquid effluents such as evaporator overheads and contaminated cooling water for treatment and discharge to a permitted outfall. 
1.1.4.1

1.1.4.2

\subsection{5}

1.1.5.1

1.1.5.2

\section{Ensure Waste Acceptance}

Ensure that dilute liquid effluents moet the acceptance criteria for treatment.

\section{Perform Transier}

Transfer the dilute liquid effluents from the generator to the treatment facility.

\section{Close Material Balance}

Ensure that all dilute liquid effluents are received at treatment facility (i.e. minimal losses).

Evaluate New Mission Waste

Perform evaluations of potential new waste streams that future SRS missions may generate. Waste acceptance criteria that control HLW System interfaces are the bases for these evaluations.

\section{Ensure Waste Acceptance}

Ensure that new mission waste will meet waste acceptance criteria in the receiving facility. This involves evaluating any proposed waste against existing criteria and, if the proposed waste is outside existing criteria, evaluating 1) if the criterin can be changed and 2) what changes in the facility are needed to accept the waste.

Designate Receipt Facility

Decide where new mission waste should be received and processed.

Prepare Receipt Facility

Prepare the receipt facility for receiving the waste by accomplishing whatever physical or procedural changes are needed.

\section{Perform Transfer}

Transfer the new mission waste from the generator to the receipt facility.

Close Material Balance

Ensure that all new mission waste is received with no losses.

1.2

Manage Tank Waste

Manage existing inventory of high-level waste and future waste receipts in 43 type I, II, and III tanks (double-shelled) and 8 type IV tanks (single-shelled).

1.2.1

Store Waste

Store SRS high-level waste in a safe and environmentally sound manner.

1.2.1.1

Maintain Tank Chemistry

Monitor the chemical composition of the waste tanks and make whatever adjustments in chemical composition are needed to ensure that waste tanks stay within appropriate limits. 


\subsubsection{Perform Inspections}

Inspect the waste tanks and associated equipment on a periodic basis to determine if any deterioration of the tanks is occurring.

\section{Perform Surveillance and Oversight}

Perform frequent surveys of the waste tanks and associated equipment, monitoring waste levels, temperatures, data loggers, control systems, and key equipment parameters to ensure that the waste tanks and equipment are operating properly. Record and archive this data as appropriate, for example in roundsheets and electronic data records.

1.2.1.4 Monitor Process Trends

Examine the data obtained from performance of surveillance and oversight to identify undesirable trends in performance of the waste tanks or equipment.

\subsubsection{Perform Equipment Maintenance}

Perform needed maintenance on the waste tanks and associated equipment.

Perform Upgrades/Enhancements

Upgrade equipment in the Tank Farm to enhance safety and efficiency, or to reduce costs.

\subsubsection{Characterize Waste}

Determine waste chemistry by a combination of process knowledge and periodic sampling. Provide physical, chemical, and radiological characterization information in support of process and corrosion control, safe issue resolution, production planning, and other neods. Waste characterization activities include sample acquisition and shipment to laboratories, laboratory analysis of samples, and review of historical data and lab results as necessary to complete characterization.

\section{Predict Composition}

Using records of waste generators and past sampling, predict the composition of waste in Tank Farm tanks. Use of prediction rather than sampling is desirable because 1 ) it avoids sample representativeness concerns and 2) it avoids the high cost of sampling and analyzing samples that are high in radiation.

\section{Sample Waste}

Seloctively sample waste to verify predictions that have been made, or to obtain data on components that cannot be confidently predicted.

\subsubsection{Package and Transport Samples}

Package samples and transport them to an appropriate laboratory.

\subsubsection{Analyze Sumples}

Analyze samples to determine their composition.

\subsubsection{Evaluate Results}

Compare sample results to predictions and to appropriate limits. 
1.2.2.6

\subsection{3}

1.2.3.1

\section{Maintain Waste Characteriantion Database}

Maintain a database of waste composition predictions and samples that can be accessed by people who need this information for production planning, safety analyses, engineering studies, etc.

\section{Transfer Waste}

Transfer waste for evaporation and to processing facilities for pretreatment and immobilization. Also, perform emergeacy transfers from leaking storage tanks if the need arises. This function includes all necessary equipment (transfer pumps, jets, etc.) to accomplich the waste transfer operation.

\section{Define Transfer Route}

For a particular transfer, define the route of pipelines, diversion boxes, and pump pits that will be used to make the transfer.

\section{Confirm Waste Compatibility}

Confirm that the waste at the destination is compatible with the waste to be sent and that the waste is being sent to the proper destination.

Verify Transfer Line/System Integrity

Verify that the transfer lines and other components used to transfer the waste are free of leaks and ready for use.

Perform Transfer

Perform the intended waste transfer

Cloce Material Balance

Ensure that all waste reaches its destination with no losses.

\section{Concentrate Waste}

Remove excess water from liquid waste to reduce volume of waste feed for pretreatment and to free storage capacity in existing tanks. This includes the processes of settling sludge and evaporating supernate.

\section{Settle Sludge}

Allow sludge to settle in the bottom of a waste receipt tank and monitor its progress via sludge soundings or other indicators.

\section{Decant Supermate}

Remove the clear supernate overlying sludge that has settled. Transfer this supernate to other tanks.

\section{Evaporate Supernate}

Evaporate the supernate by boiling, which drives off water. Collect the overbeads and condeose. Retum the evaponted conceatrate to a waste tank.

\section{Pre-Treat Overheads and RBOF Waste}

If necessary, pre-treat overheads and RBOF waste to remove Cs-137. The waste can then be sent for further treatment.

\subsection{Pretreat Waste}

Separate tank waste into a high-level and low-level fractions suitable for immobilization, a fraction suitable for reuse in waste removal, and a fraction 
suitable for release as liquid effluent. Pretreatment includes removing waste from existing storage tanks, separating the constituents suitable for immobilization as low-level waste Saltstone, reuse, or disposal as liquid effluent, and converting the remaining fraction into feeds for the high-level waste immobilization facility (i.e., the DWPF).

1.3.1 Remore Waste

Remove waste (salt and sludge) from the existing underground storage tanks for transfer to pretreatment facilities. Waste to be removed include liquids, salt cake, and sludges. Also, other materials may be removed as appropriate (e.g., failed equipment, zeolite, sand, etc.).

1.3.1.1

1.3.1.2

\section{Remove Failed or Unneeded Equipment}

When a waste tank is ready for the waste to be removed, remove from the tank equipment that has failed or is no longer needed.

\section{Dissolve Salt}

Add water or other slurry medium to waste tanks containing salt and agitate to dissolve the salt. The waste is then ready for transfer (function 1.2.3)

\section{Slurry Sludge}

Add water or other slurry medium to waste tanks containing sludge and agitate to suspend the sludge. The waste is then ready for transfer

- (function 1.2.3)

\section{Remore Residues (Zeolite, etc)}

Remove residues (such as zeolite) that are not readily removed using the slurry techniques planned for salt and sludge.

\section{Wash Tank}

Spray the tank with water to remove small amounts of waste clinging to the walls, roof, cooling coils, etc.

\section{Prepare Tank for Future Operations and/or Disposition}

Prepare the tank for its future mission. For some taniks, this will mean preparing the tank for waste receipts. For tanks that don't have a future process mission, this may mean further cleaning that will prepare it for closure as a waste site, or it may involve other preparations. The scope of this function is not well defined at this time and must be closely integrated into plans for closure of the tanks as waste sites.

\subsubsection{Process Salt}

Process dissolved salt solution to remove radionuclides and fissile materials to produce fractions suitable for immobilization as low-level waste (Saltstone) and re-use, and feed the concentrated radionuclides to immobilization (in DWPF).

Ensure that waste received for salt processing meets the waste acceptance criteris.

\subsubsection{Decontaminate Salt}

Remove hazardous radionuclides from the salt by precipitation. 
1.3.2.3

1.3.2.4

1.4.
Concentrate Slurry

Concentrate the precipitate by filtration.

\section{Wash Precipitate}

Wash the precipitate with water to reduce the concentration of soluble salts.

Remove Benvense

Remove the benzene from the decontaminated salt solution that is produced during filtration.

\section{Late Wash Precipitnte}

Just before transfer to glasemaking, wash the procipitate to appropriate levels for incorporation into glass.

\section{Proceses Sludize}

Wash waste sludge to remove excess dissolved salts and aluminum to provide suitable feed for immobilization in glass.

\section{Ensure Waste Acceptance}

Ensure that sludge received into sludge processing meets waste acceptance criteria.

\section{Dissolve Aluminum}

Convert the insoluble aluminum compounds in the sludge into soluble compounds.

\section{Wash Sludge}

Remove soluble salts from the sludge by washing it with water.

Immobilize Waste

Process high-level waste sludge and decontaminated salt solution into immobilized forms suitable for long-term storage and disposal.

\subsection{1 \\ Vitrify Waste}

Vitrify high-level waste that has been stored in the SRS tank farms. Vitrify pretreated high-level waste (i.e., precipitated salt solution and washed sludge), seal the vitrified waste into primary stainless steel canisters, decontaminated the outer surfaces of the canister, test canister integrity, and store prior to shipment to the federal repository.

\subsubsection{Ensure Waste Acceptance}

Ensure that any waste accepted into the vitrification plant meets waste acceptance criteria.

\section{Hydrolyze Precipitate}

Hydrolyze the precipitate to remove the organic constituents, which would interfere with glass production in the melter.

\subsubsection{Prepare Melter Feed}

Prepare the sludge feed and mix with the precipitate and glass formers to produce a slurry suitable for glass melting. 


\subsubsection{4}

1.4.1.6

1.4 .2
Vitrify Feed

Send the melter feed to a glass melter and produce a waste glass.

\section{Proces Canisters}

Process the canisters to prepare them for disposal, i.e. welding, decontamination, and testing; store them in preparation for final disposal.

\section{Ensure Waste Compliance}

Ensure that the canistered glass wasteform meets all appropriate requirements and that all supporting documentation and certification has been accomplisbed.

\section{Produce Saltstone}

Immobilize decontaminated salt solution by mixing with fly-ash, slag, and cement to form a concrete waste form called Saltstone, and dispose of the immobilized waste in on-site vaults.

\section{Ensure Waste Acceptance}

Ensure that any waste accepted into Saltstone meets waste acceptance criteria.

\section{Produce Grout}

Mix the salt solution waste with cement formers to produce a cement-like wet grout.

\section{Pump Grout}

Pump the grout to \&altstone Vault (The Saltstone vault and landfill are outside of the HLW System).

\section{Close Vaults (Outside of the HLW System)}

Close the Saltstone vaults as a landfill via approved permits and regulatory protocols.

\section{Manage System Generated Waste and Excess Facilities}

Manage waste and excess facilities generated while remediating the existing tank waste. Activities to be managed include disposition of liquid, gaseous, and organic effluents, packaging of miscellaneous low-level solid wastes for on-site storage, disposition of excess facilities, and the recycling of reusable materials.

\subsubsection{Mange Liquid Effluents}

Collect, treat, and discharge all radioactively contaminated process wastewater from the HLW System. This function includes operation and maintenance of the F/H Effluent Treatment Facility (ETF).

\subsubsection{Treat Low-Level Effucents}

Treat waste that has been received (see function 1.1.4). Decontaminate low-level effluents, such as evaporator overheads. Send the treated water to the environment, and send the concentrated contaminants to Saltstone.

\subsubsection{Manage Stormwater}

Monitor stormwater for contamination. If contaminated, or if there is a risk of contamination (even if none is detected), diver the stormwater to a stormwater collection basin for treatment. 


\section{Mannge Non-Contect Process Streams}

Monitor non-contact process streams for contamination. If contaminated, or if there is a risk of contamination (even if none is detected), divert the non-contact process streams to a collection basin for treatment.

\subsection{2}

Manage Solid Wastes

Package, characterize, and ship solid waste in a manner that meets Solid Waste Acceptance Criteria. Solid waste includes low-level radionctive waste, mixed low-level and transuranic waste, transuranic waste, and non-radioactive waste.

\section{Manage Gaseous Emuents}

Collect, treat, monitor, and discharge gaseous effluents generated from HLW processing operations. Exhaust effluent streams to the environment while maintaining discharges within regulated limits.

\subsubsection{Characterize Efrluents}

Determine the constituents, quantities, and emission points of gaseous effluents.

\section{Ensure Compliance}

Evaluate the effluent characterization and ensure that gaseous effluents are within regulatory and DOE requirements.

\subsubsection{Operate Off-Gas Systems}

Operate off-gas systems that mitigate air emissions. 
1.5.3.4 Monitor Operations

Monitor gaseous emissions as appropriate to ensure that systems are operating properly, emissions are within limits, and all regulatory requirements for monitoring are satisfied.

1.5.4 Manage Organic Effluents

Collect organic effluents, treat as required to meet disposal facility criteria, and store for processing/disposal. This function includes storage and transfer of materials to the Consolidated Incinerator Facility (CIF).

\section{Characterize Emuents}

Determine the composition of the organic effluent by process knowledge and sampling.

\section{Store Recovered Organic Materials}

Store recovered organic materials in a safe and environmentally sound manner.

\section{Transfer Organic Emuents}

Transfer organic effluents to incineration.

\section{Disposition Excess Facilities}

Empty, decontaminated, and deactivate excess facilities, prepare excess facilities for disposition by the Environmental Restoration Division. Identify and/or remove chemical inventories, decontaminate or stabilize work areas, shut down non-essential support systems, and isolate tanks. Excess facilities are those structures used in the storage, treatment, or processing of high-level waste that have no future identifiable or planned programmatic use. Examples of excess facilities include waste tanks, transfer lines, waste evaporators, and pretreatment facilities. SCDHEC, EPA, and DOE have agreed that CERCLA is the appropriate regulatory vehicle for closure of the high-level waste tanks and associated facilities. ${ }^{3}$

\subsubsection{Characterive Residual Contamination}

Determine the residual amount of contamination in excess facilities by process knowledge, sampling, or other means.

\subsubsection{2}

\section{Define D\&D Operation}

Define the proper means to disposition each excess facility.

\subsubsection{Disposition Reusable Materials}

Collect, treat, store, package, and transfer materials that are economically suitable for reuse. Major types of reusable materials include scrap metal, scrap iron, and process equipment that can be decontaminated to levels sufficient for transportation and use in non-radioactive environments.

\section{Characterize Materials}

Characterize materials that are to be reused.

1.5.6.2 Treat

If appropriate, treat reusable materials so that they are suitable for their intended use. 


\subsubsection{Store Reusable Materials}

Store reusable materials in a safe and environmentally sound manner.

\subsubsection{Define Customer/Use}

Define who will use the materials and how they will be used.

\subsubsection{Transport Materials}

Transport the reusable materials to the intended user.

\subsection{Allocation of HLW System Functions to HLW Processes}

All of the processes required to carry out the above functions already exist or are in the final stages of construction and start-up testing. The functions bave been allocated to the HLW Processes as listed below:

\begin{tabular}{|c|c|c|}
\hline Level 2 Function & HLW Processes & $\begin{array}{l}\text { Described in } \\
\text { Chapter } \\
\text { number(s) }\end{array}$ \\
\hline Receive Wasto & $\begin{array}{l}\text { HLW Storage and Evaporation (F- and H-area Tank } \\
\text { Farm), Effluent Treatment Facility }\end{array}$ & 5,9 \\
\hline Manage Tank Waste & $\begin{array}{l}\text { HLW Storage and Evaporation (F- and H-area Tank } \\
\text { Farm) }\end{array}$ & 5 \\
\hline Pretreat Waste & $\begin{array}{l}\text { In-Tank Precipitation, DWPF Late Wash Facility } \\
\text { Extended Sludge Processing }\end{array}$ & $6,8,9$ \\
\hline Immobilize. Waste & $\begin{array}{l}\text { DWPF Pre-treatment, DWPF Vitrification, DWPF } \\
\text { Saltstone, transfer wet Saltstone grout to Saltstone } \\
\text { Disposal Facility }\end{array}$ & 8,10 \\
\hline $\begin{array}{l}\text { Manage System Generated } \\
\text { Waste and Excess Facilities }\end{array}$ & $\begin{array}{l}\text { Efflueat Treatment Facility; transfer benzene to } \\
\text { Consolidated Incinerator Facility; Solid waste to } \\
\text { SRS Solid Waste Management Facilities }\end{array}$ & $\begin{array}{l}9,8 \text { (Solid } \\
\text { Waste is } \\
\text { outside scope } \\
\text { of PID) }\end{array}$ \\
\hline
\end{tabular}

These HLW Processes, their interfuces, and their functions and requirements are described in the sections that follow. These processes are interconnected by pipelines and function as a large integrated treatment plant that receives, stores, and treats high-level waste from various SRS generators and converts them into forms suitable for final disposal. A complete description of the HLW System is provided in the HLW System Plan. ${ }^{\circ}$

It should be noted that the approach taken in allocating the functions to processes followed the "reverse" systems engineering approach noted previously. In a traditional systems engineering approach, the next step after identifying the functions would be to identify the requirements for each function, and the following step would be to identify candidate processes for each function. This approach is beneficial in 
ensuring that all promising candidate processes are identified in the early stages of defining the system configuration.

However, at SRS, candidate processes for accomplishing HLW functions have been studied over the last 15 years, and the system configuration has been defined as a result of considerable studies on alternative processes to accomplish the required functions, for example, ion exchange for salt processing, centrifugation for sludge processing, tailored ceramics and cement waste forms for immobilization, alternatives to ETF processes, stainless steel tanks for processing waste, etc. As a result of this work, the functional requirements and preferred system configuration are already known, and there is minimal benefit to rigorously defining requirements for each level 1, level 2, level 3, and level 4 function identified in the previous section. A more useful approach is to define requirements for each of the HLW processes because this is directly applicable to system planning and integration.

Therefore, the remainder of this document concentrates on the actual HLW Processes, their functions, interfaces, and requirements.

\subsection{Defining the HLW Processes and Interfaces}

The PID defines 20 interfaces between HLW Processes (see next chapter) and provides the technical bases for control of these interfaces. For the PID to effectively perform its function, the HLW Processes and the interfaces between them must be carefully defined. Although some of the divisions are relatively straightforward, some facilities can logically be considered to be in more than one processes. For example, the DWPF Late Wash facility could be logically considered 1) part of ITP, since it uses the same process as ITP and finishes the function of processing salt (function 1.3.2) that ITP starts, 2) part of DWPF, since it is close-coupled to DWPF and begins the job of processing the precipitate, or 3) a completely separate process.

In carving up the HLW system into HLW Processes and interfaces, the PID team chose boundaries that would be most effective at meeting the objectives of 1 ) providing enough control to ensure that changes are properly reviewed, while 2) avoiding unnecessary interference in the operation of each process.

For example, in the case of the Late Wash facility, if Late Wash were considered part of ITP or a separate process, this would result in an division-level interface between Late Wash and DWPF Vitrification. This would require division-level review of any changes to this interface. In the opinion of the PID team, treating Late Wash and Vitrification as part of one process is better because the two facilities are close-coupled, the composition change in Late Wash is minimal (washing of soluble salts) with little impact on the rest of the HLW System, and both facilities are controlled by the DWPF organization. Thus, the team defined Late Wash as being part of the DWPF Vitrification Process.

Another example is that air emissions from DWPF (and other processes) are not included because these can be controlled within the DWPF's technical baseline. Air emissions limits will have an impact on interfaces within the scope of the PID, specifically composition requirements on the washed sludge and precipitate. These requirements are reflected in the DWPF Feed Design Bases document thus are indirectly under the control of the PID.

The following three sections provide more explanation of how the interface concept belps the PID perform its function. 


\subsubsection{Relationship of the Process Interface Description and HLW Process Tochnical Baselines}

Since the PID is a division-level document, considerable review and approval will be required throughout the division to make changes. Therefore, to promote cost-effective and efficient decision-making in the HIW System, it is desirable to judiciously restrict the scope of the document to those items that truly have an impact throughout the division. The ideal structure would cause decisions to be made as follows:

1. Decisions affecting only one HLW Process should be made within that HLW Process. No other HLW Process would be involved.

2. Decisions that affect only the interface between two HLW Processes should be made by the two respective organizations, although some division-level review would be required.

3. Decisions with far reaching impact (such as the use of a new chemical, or the construction of a major new process, such as Late Wash), should be elevated to the division level and reviewed by the management of all HLW Processes.

To accomplish this ideal control structure, the PID concentrates primarily on the interfaces between HLW Processes. This structure is illustrated schematically in Figure 3-1. 
Figure 3-1

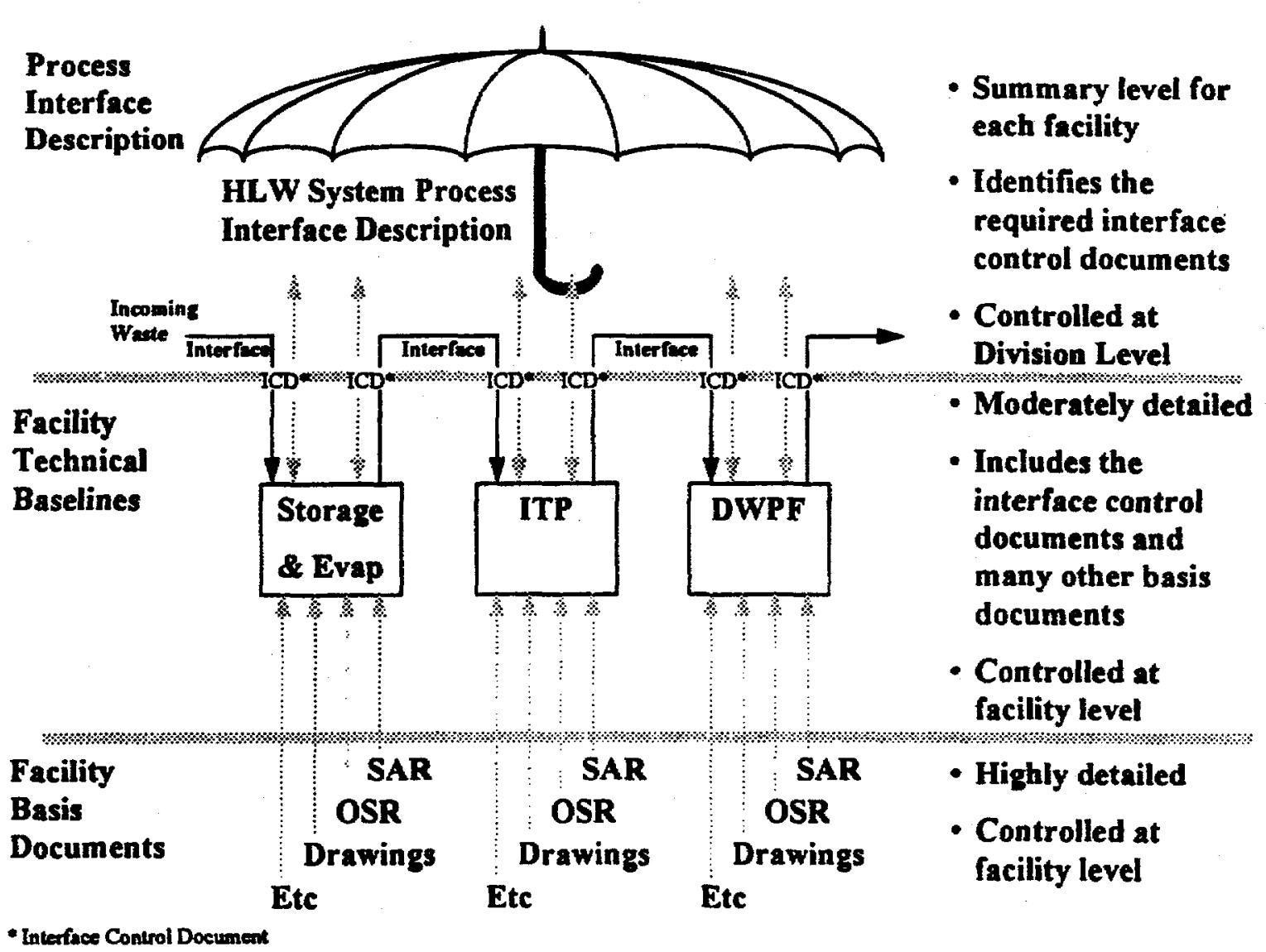

\subsubsection{Definition of an Interface}

A HLW Interface is defined as a boundary in the HLW System through which wastes are being exchanged between HLW Processes or between a HLW Process and an external process. A few such interfaces are shown in Figure 3-1 (for a complete list, see Figures 4-1 and 4-2; and Table 11-8). Each interface has associated interface control documents. Generally, each interface has at least two documents: 1) a document from the receiving organization defining the important parameters (chemical and radionuclide concentrations, flows, temperatures, etc.) for that stream, and 2) a document written by the sending organization describing how it will control the stream. The interface documents for each interface represent an agreement between the two organizations on how the interface will be managed. In the future, plans are to consolidate some of these interface documents to reduce the number of documents required to regulate each interface.

These interface control documents are part of both the PID and the technical baselines for the HLW Processes to which they apply. Since these documents are part of the HLW Process's technical baseline, when a HLW Process technical baseline is changed, the interface control documents must be reviewed for potential impact. Similarly, when an interface control document is revised, the HLW Process's technical baseline must be reviewed. 


\subsubsection{Application of the Interface Concept}

By concentrating mainly on the interfaces between HLW Processes, the PID will tend to promote decision making at the appropriate levels, as a few examples will illustrate:

1. In the HLW Storage and Evaporation Process, hydrogen is produced by the radiolysis of water. The generation of hydrogen is a critical safety concern and dominates the Tank Farm safety analyses. However, this safety concern has very little impact outside of Storage and Evaporation and does not appear in any interface document. Therefore, this safety concern is handled entirely within the technical beseline for Storage and Evaporation and is not addressed in the Process Interface Description.

2. Nitrites and nitrates in the sludge feed to DWPF will cause $\mathrm{NO}_{x}$ emissions from the DWPF. Therefore, this concem is addreseed in the DWPF Feed Design Bases, the document that describes important parameters in streams entering the DWPF. The concentrations of these species is controlled in Extended Sludge Processing and will be addressed in the Interface Control Document for washed sludge. However, there is minimal impact outside of these two HLW Processes, so decisions about these concentrations will be restricted primarily to personnel at Extended Sludge Processing and the DWPF, although some division-level review is required.

3. The addition of a new chemical in a process could potentially have impacts on all downstream processes. Thus, it would receive wide review throughout the HLWM division. 


\section{SRS HIGH-LEVEL WASTE PROCESSES AND INTERFACES}

\subsection{Overall High-Level Waste Process Description}

This chapter is organized by broad categories of wastes that are received into the HLW System, specifically:

1. Routine Wastes-wastes normally received and processed through the HLW System. Most of the wastes received into the HLW System will fall into this category.

2. Contamination Control Wastes-wastes resulting from process incidents or upsets, in which potentially large quantities of aqueous wastes are produced that must be processed.

3. Non-routine minor wastes-waste that are received occasionally, but can be anticipated in advance, and whose volumes and chemical content are small relative to the normal streams.

4. Unique and unusual wastes-non-routine wastes that are handled on a case-by-case basis. Some of these wastes, though unique, may be similar to wastes usually processed. Others may be completely unlike any waste normally processed.

The processes for each of these broad categories is discussed in the four subsections that follow.

\subsubsection{Routine Wastes}

\subsubsection{High-Level Waste Treatment}

Figure 4-1 schematically illustrates the routine flow of wastes through the HLW System. The various processes within the system and external processes are shown in rectangles. The numbered streams identified in italics are the interface streams between the various processes. These interface stream numbers are used throughout the PID and in tables and figures. See section 3.4 for a description of how the interfaces were chosen. See the tables in chapter 11 for a description of how the interfaces are controlled.

Incoming High-Level Wastes (Interface Stream 1) are received into HLW Storage and Evaporation. The purpose of the Storage and Evaporation process is to safely store these wastes until downstream processes are available for further processing. As an extension of storage, some of the salt wastes are evaporated to a solid saltcake to reduce their volume and mobility (the saltcake is later redissolved with water before being sent on to further processing, i.e. there is no intent to change the composition of the waste). The decontaminated overheads from the evaporators are sent to the ETF (Interface Stream 13).

The insoluble sludges that settle to the bottom of waste receipt tanks in Storage and Evaporation are slurried using hydraulic slurrying techniques and sent to Extended Sludge Processing (ESP) (Interface Stream 2). In ESP, sludges high in aluminum are processed to remove some of the insoluble aluminum compounds. All sludges, including those that bave been processed to remove aluminum, are washed with water to reduce their soluble salt content. The spent washwater from this process is sent back to the Storage and Evaporation (Interface Stream 3). The washed sludge is sent to DWPF Feed Pretreatment and Vitrification (Interface Stream 4). 


\section{Figure 4-1: HLW System Major Interfaces}

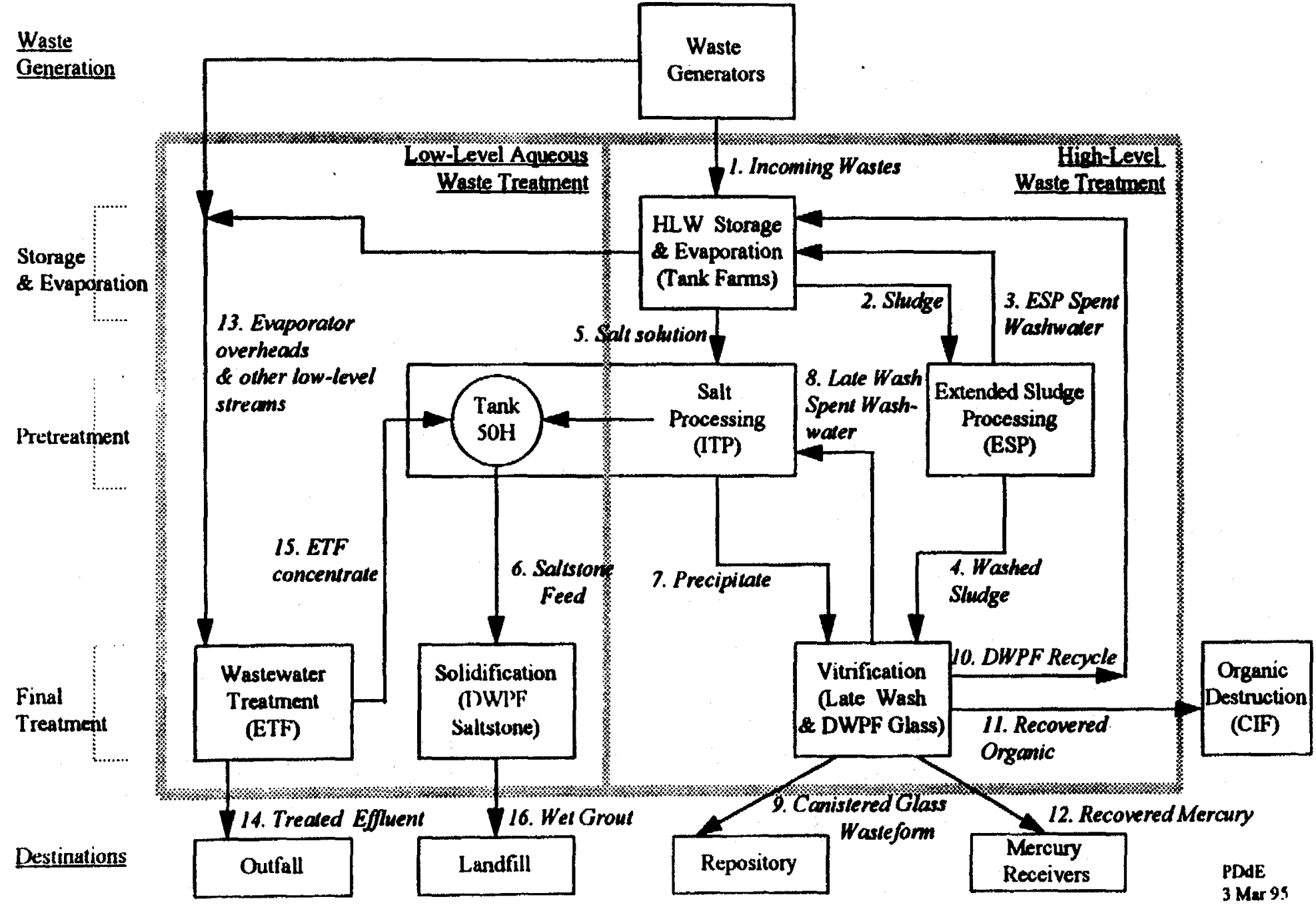




\section{Figure 4-2: HLW Contamination Control Streams}

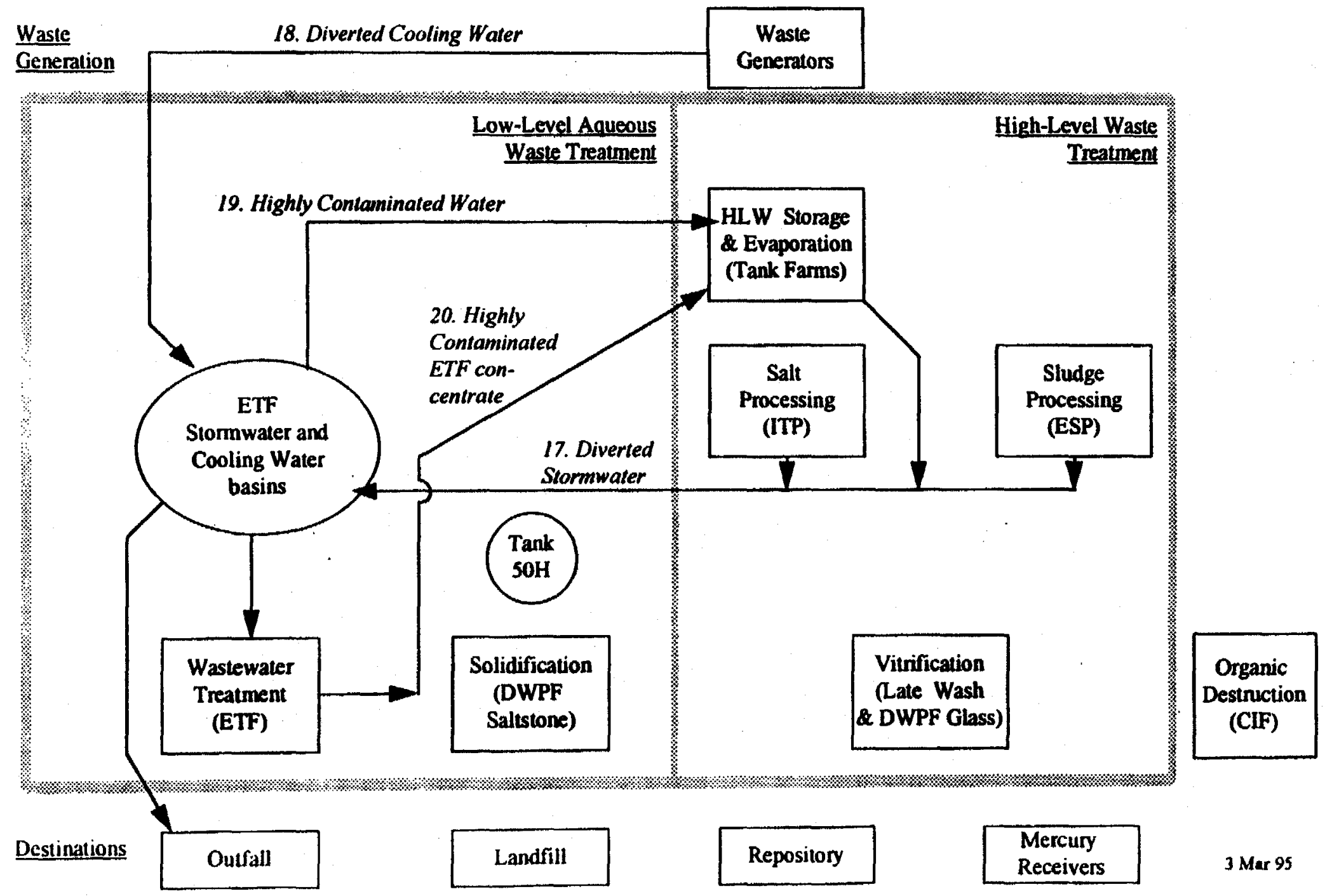


Saltcake is redissolved using hydraulic slurrying techniques similar to sludge slurrying. The salt solutions from this operation, and other salt solutions from Storage and Evaporation, are sent to In-Tank Precipitation (ITP) (Interface Stream 5). In ITP, the salt solution is processed to remove radionuclides, which are concentrated into an organic precipitate. The decontaminated supermate is sent to Tank $50 \mathrm{H}$, which is administratively controlled as part of ITP. A concentrated organic precipitate, containing most of the radionuclides, is produced by the process. This precipitate is washed with water to remove soluble salts and sent to Vitrification (Interface Stream 7), specifically the Late Wash Facility. However, some soluble corrosion inhibitors (which interfere with DWPF processing) must be left in the precipitate after washing because the precipitate is stored in carbon steel tanks, which are susceptible to corrosive attack by uninhibited precipitate wastes.

In DWPF Late Wash, the precipitate is further washed in stainless steel tanks to reduce the level of soluble corrosion inhibitors to levels acceptable to the DWPF process. The washwater from this process is returned to the ITP process (Interface Stream 8) to be reused in the ITP process.

The washed precipitate from Late Wash is then sent to the DWPF Vitrification building (221-S). In the vitrification building, the precipitate is catalytically decomposed and separated into two streams: a mildly contaminated organic stream, which is sent to storage and eventual organic destruction in the Consolidated Incineration Facility (Interface Stream 11), and an aqueous stream containing virtually all of the radionuclides. The aqueous stream is combined with the washed sludge from ESP, which has undergone further processing (see next paragraph), and the mixture is sent to glass melting.

The washed sludge from ESP (laterface Stream 4) is chemically adjusted in the DWPF to prepare the sludge for feed to the glass melter. As part of this process, a significant amount of mercury is stripped out, which is purified and sent to mercury receivers (Interface Stream 12). The aqueous product from organic decomposition is added to the chemically adjusted sludge. The mixture is then mixed with glass frit and send to glass melting. The glass melter drives off the water and melts the wastes into a borosilicate glass matrix, which is poured into a canister. The canistered glass wasteform (Interface Stream 9) is sent to on site interim storage, and will eventually be disposed of in a Federal Repository.

The water vapor driven off from the melter along with other aqueous streams generated throughout the DWPF Vitrification building are recycled to Storage and Evaporation for evaporation, storage, and eventual further processing (Interface Stream 10).

\subsubsection{Low-Level Aquoous Waste Treatment}

Overheads from the Storage and Evaporation evaporators are combined with overheads from evaporators in the F- and H-area Separations processes and other low-level streams from various waste generators. This mixture of low-level wastes is sent to the Effluent Treatment Facility (ETF). (Interface Stream 13)

In the ETF, these low-level wastes are decontaminated by a series of cleaning processes. The decontaminated water effluent is sent to the $\mathrm{H}$-area outfall and eventually flows to on site crecks and the Savannah River (Interface Stream 14). The contaminants removed from the water are concentrated and sent to Tank 50H (Interface Stream 15).

In Tank 50H (administratively controlled as part of ITP), the concentrate from the ETF is combined with the decontaminated supernate from ITP. This mixture of wastes is then sent to Saitstone (Interface Stream 6). In Saltstone, the liquid waste is combined with cement formers and purnped as a wet grout (Interface Stream 16) to a vault. In the vault, the cement formers hydrate and cure, forming a Saltstone monolith that will eventually be closed as a landfill. 


\subsubsection{Contamination Control Wastes}

Contamination Control wastes are wastes resulting from process upsets or accidents that contaminate large amounts of water. Examples of such accidents include a HLW evaporator tube bundle leak, a leak in a canyon vessel cooling water coil or stream coil, or a flushwater line leak (Tank 13H accident). Any of these accidents have the potential to contaminate large quantities of storm water, cooling water, or steam condensate. The flow of such wastes is schematically illustrated in Figure 4-2.

Diverted Stormwater (Interface Stream 17) is any large volume of contaminated or potentially contaminated water from the Tank Farms. Since any of these streams would be sent to the stormwater collection system, they are grouped together as "Diverted Stormwater." Stormwater is collected from specific monitored zones in the Tank Farms (Including Storage and Evaporation, ITP, and ESP) and is monitored for radionctivity in the storm sewers. If the water is contaminated, the water is diverted to a stormwater basin. Also, during certain operations in the Tank Farms that have the potential to release contamination, such as transfers, stormwater is procedurally diverted to the storm sewers to increase the assurance that any contaminated water is captured. There are also other reasons for these precautionary diversions, such as when monitoring equipment is inoperable. Such precautionary diversions usually contain a negligible amount of radioactivity but represent a significent fraction of the volume of this stream.

Other sources of contaminated water that might contribute to this stream are contaminated steam condensate (for example, from a failed evaporator tube bundle) and contaminated cooling water.

Diverted Cooling Water (Interface Stream 18) is contaminated water from the F- or H-area Separations process. Water and steam are used for cooling and heating, respectively, in Separations tanks. If the heating or cooling coils leaks, the water becomes contaminated. Therefore, this water is monitored after leaving the canyon. If it is contaminated, the water is diverted to a cooling water basin.

If the water from a diversion of stormwater or cooling water is found to be very highly contaminated, it cannot be safely processed through the ETF. Therefore, the very highly contaminated water would be sent directly to a waste tank in the Storage and Evaporation process via the HDB-8 diversion box (Interface Stream 19). However, all diversions to date have resulted in low levels of contamination that can be processed through the normal ETF processes and handled as normal waste (see previous section). There is also the possibility that waste would be contaminated to some intermediate level such that it could be safely processed through all or part of the ETF process but the resulting concentrate would be too contaminated to send to Tank 50H. In that case, the ETF concentrate would be sent to a waste tank in the Storage and Evaporatioa process via the HDB-8 diversion box (Interface Stream 20).

\subsubsection{Non-Routine Minor Wastes}

These are wastes whose volume and chemical content are smalt relative to normal streams, i.e. they are easily handled by standard practices and procedures The PID does not attempt to establish the technical basis for each of these streams. These streams should be controlled in the Interface Control Documents for HLW Processes and are regulated under the SIMP.

An example of a stream of this type would be water from ITP dikes. The water is collected and analyzed. If the water is clean, it is discharged as stormwater. However, if it were to be contaminated with benzene, it would be sent to ETF. 


\subsubsection{Unusual and Unique Wastes}

As the words imply, unusual and unique wastes are thoce wastes that are one-of-a-kind, or wastes that are similar to normal wastes but with some unusual aspect. . An example of such waste is the tritiated water from the reactor areas that was received into Tank 17F in January 1992.

No attempt is made in this document to predict and eatablish the technical basis for all the possible wastes that might be received in the HLW System. Such wastes must be controlled on a case-by-case basis. However, a fow general principles apply to control of such wastes:

- The composition of each waste stream must be characterized and documented.

- All such wastes must be approved on a case-by-case basis by the management of the receiving HLW Process.

- The review should consider the effect on downstream interfaces. If the review shows that the receipt involves new chemicals or has the potential to impact downstream interfaces, then management of the receiving HLW Process is responsible for requiring further review, as appropriate.

- Any review of an unusual stream must be documented.

\subsection{DWPF Feed Acceptance}

A critical mission-level need in the HLW system is that the DWPF processes-Vitrification and Saltstone-must operate efficiently and safely and must produce acceptable product. Although the DWPF processes are designed to accept the range of compositions expected in the tank farms, there is the potential that small batches of waste may exist that could impact operation of the DWPF if they are not anticipated. Also, much of this waste has been deposited over 40 years of operation, and the information on composition of the waste is limited.

To alleviate this concern, it would be desirable to blend the salt and sludge wastea before sending them to the DWPF. Blending would tend to dampen the swings of compositions and reduce the potential for unintended disruptions of the process. Some blending is already planned as a natural result of the waste removal schedule. For example, the amount of sludge in most tanks is small, and several tanks must be combined to form one batch of feed for DWPF. Also, in ITP a number of batches of precipitate will be combined in Tank 49H, the feed tank for DWPF, so that the precipitate sent to DWPF will always contain wastes from more than one salt tank.

However, the amount of blending that is planned is limited. For smooth operation of HLW Processes, it would be desirable to determine the composition of each tank and purposely blend tanks that are high in one constituent with tanks that are low in the same constituent. This would limit the variations in the composition of wastes sent to Vitrification and Saltstone, making it simpler to ensure that these processes produce acceptable product.

The ability of the HLW Storage and Evaporation to blend wastes to achieve more uniform feed composition is limited for a number of reasons:

- The Tank Farms currently do not have enough space to perform blending among a large number of tanks. Only a few tanks at a time can be blended, greatly limiting the blending options.

Plans are to process the first several salt tanks one at a time. 

operation of the Evaporator systems, wastes must be removed from specific receipt tanks so that sufficient space is available.

- Removing the waste from a tank requires a long lead time for design, construction, and startup of waste removal facilities. Thus, scheduling of tanks in the next ten years is constrained by existing projects, budgets, and available tank spece. The waste must be removed from the tanks that are already scheduled or there will be considerable penalties in time and budget.

- Knowledge of the waste compositions in individual tonks is limited, which will limit confidence in predictions about the waste produced by a given blending scheme.

\subsubsection{HLW Material Evaluation Board}

To address the concerns about the composition of sludge and salt solution sent to processing, a DWPF Feed Acceptance Process is being established to evaluate the scheduling of wastes for waste removal. The feed acceptance process is described in the SIMP. ${ }^{30}$

A key part of this process is that the HLWM Division Chief Engineer will appoint a HLW Material Evaluation Board to review the scheduling of wastes for disposal and develop strategies for working around any problems that are found. This board may be a new board or may be an added responsibility to an existing group, at the discretion of the HLWM Division Chief Engineer. What's important is that the function of the board is accomplished.

The HLW Material Evaluation Board has the following responsibilities:

- Prepare batch-by-batch estimates of the composition of sludge, precipitate, and salt solution sent to DWPF Vitrification and Saltstone.

- Review changes to the High-Level Waste System Plan that impact the order or blending volumes of batches being sent to the DWPF and Saltstone.

- If batches are planned that are out of the DWPF Feed Design Bases, the Material Evaluation Board will determine the impect of processing these betches.

- Recommend corrective actions to management when planned batches are discovered that are out of specifications, or when the information is insufficient to confidently predict the compositions. Such corrective actions might include revision of the blending scheme, changes to the process (such as revising the DWPF batch recipe), or further determination of waste composition through process knowledge or sampling.

The Material Evaluation Board will report to the High-Level Waste Technical Oversight Steering Team (TOST), a board chaired by the HLWM Division Chief Engineer and composed of level 3 managers responsible for the various HLW Processes and representation from DOE HLW Management. The TOST will be responsible for reviewing the recommendations made by the HLW Material Evaluation Board and approving changes to the High-Level Waste System Plan. 


\subsection{HLW Processes}

The following six chapters discuss the six interconnected HLW Processes. The purpose of these chapters is to describe the key charncteristics of each HLW Process, and to describe the key process controls and variables that are important for each HLW Process to function properly in the high-level waste system. The succeeding chapter (Chapter 11, "Control of HLW Procese Interfaces") describes the actual controls and the interface control documents for each interface.

The chapters are as follows

5. High-Level Waste Storage and Evaporation (Tank Furms)

6. Salt Processing (In-Tank Precipitation)

7. Extended Sludge Processing

8. Vitrification (DWPF Late Wash, Pretreatment, and Vitrification)

9. Wastewater Treatment (Effluent Treatment Facility)

10. Solidification (DWPF Saltstone)

For each HLW Process, the following topics are discussed:

- Function of the HLW Process

- Description of the HLW Process

- Influent Streams and Key Process Variables

- Effluent Streams and Key Process Controls 


\section{HIGH-LEVEL WASTE STORAGE AND EVAPORATION}

\subsection{Function}

The HLW Storage and Evaporation Process stores high-level waste in a safe and environmentally sound manner until downstream processes are available to process the waste into forms suitable for final disposal.

Once downstream processes are available to process a tank of waste, the waste is removed from the tanks and sent for further processing.

\subsection{Description of the Storage and Evaporation Process}

Distributed between $F$ and $H$ areas are 51 tanks designed to store high-level waste. These tanks and associated equipment are known as the $\mathrm{F}$ and $\mathrm{H}$-area Tank Farms.

The HLW Storage and Evaporation Process means those tanks, evaporators, and associated equipment dedicated primarily to storage of the waste, which includes evaporation. Specifically, this includes the following tanks and associated transfer lines, diversion boxes, pump pits, and evaporators: Tanks 1-21, $23-39,41,43-47$.

The following tanks are located in H-aren Tank Farm but are reserved for other purposes and are associated with other HLW Proceseses as follows:

- Tanks 22H, 48H, 49H--In-Tank Precipitation (Surveillance of Tank 22H is administratively controlled by Storage and Evaporation, but transfers into and out of the tank are controlled by ITP, i.e., for process purposes it is an ITP tank). Discussed in Chapter 6.

- Tanks 40H, 42H, and 51H-Extended Sludge Processing. Discussed in Chapter 7.

- Tank 50H-Saltstone Feed (Administratively controlled as part of In-Tank Precipitation). Discussed in Chapters 6 and 10.

A diagram of the Storage and Evaporation Processes is shown in Figure 5-1.

The 51 high-level waste tanks at SRS are of four types, as follows: ${ }^{7}$

Type I Tanks These are tanks 1-12, the original tweive tanks built at SRS. The primary tanks are constructed of carbon steel with a design capacity of 750,000 gallons. Each tank has a carbon steel annulus pan, five feet in height, which is underneath the primary tank to catch leaked waste (sometimes referred to as cup-and-saucer construction). The primary tank and annulus pan are enclosed in a concrete vault. Five of these tanks (Tanks 1,9,10,11, and 12) bave leaked observable quantities of waste from primary containment into the annulus pans. Also, none of the tanks meet current DOE or regulatory criteria for secondary containment. Thus, emptying and retiring these tanks is a high priority in the HLW System. 
Figure 5-1

\section{HLW Storage and Evaporation}

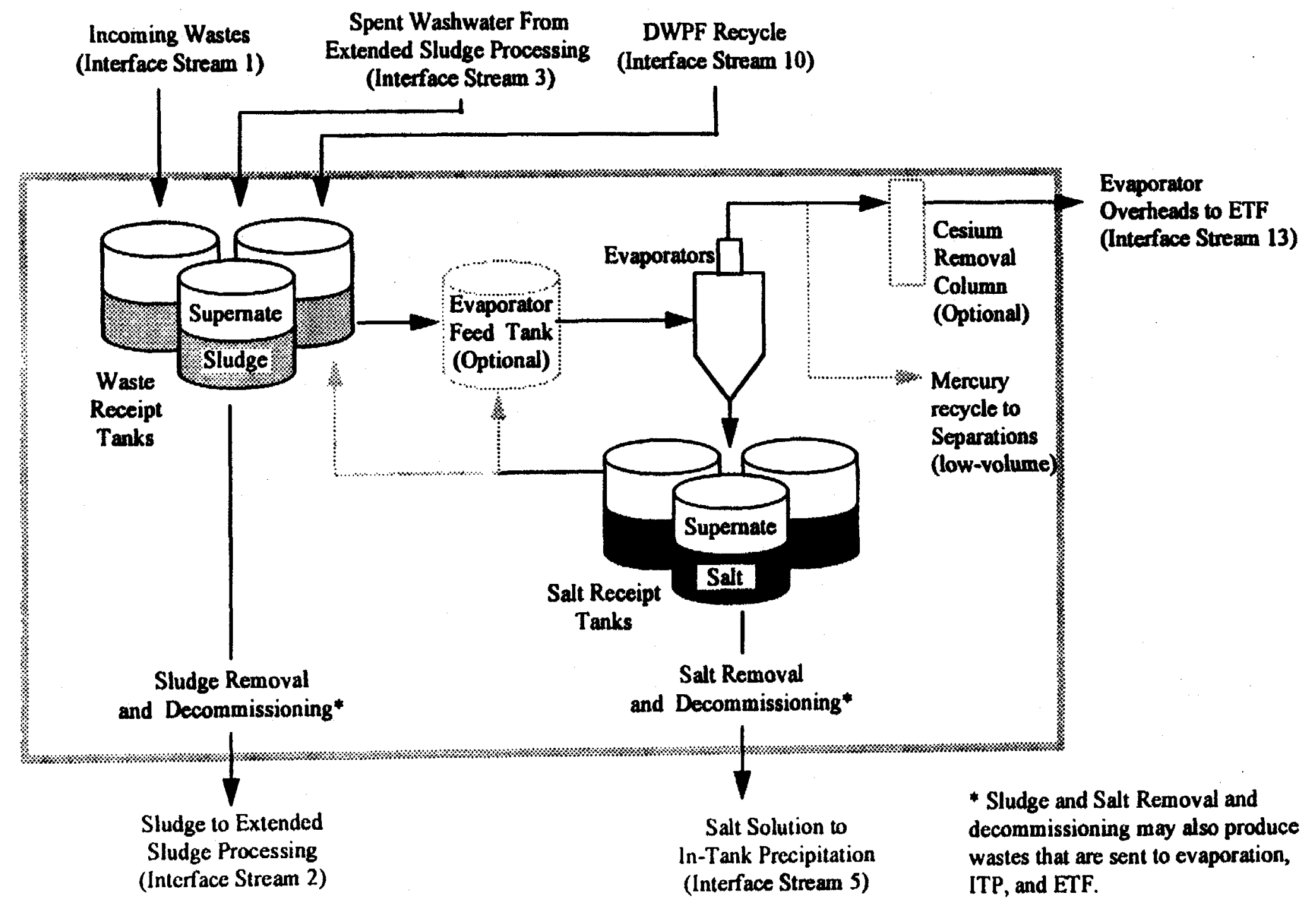


Type II Tanks These are tanks 13-16. The primary tanks are constructed of carbon steel with a design capacity of $1,030,000$ gallons. Similar to the type I tanks, each tank has a five-foot annulus pan and a concrete vault. All four of these tanks have leaked waste from the primary into the annulus pan. In 1960, one tank, Tank 16H, overflowed its annulus pan and leaked some tens of gallons of waste into the soil. None of the tanks meet current DOE or regulatory criteria for secondary containment. Emptying and retiring these tanks is also a high priority in the HLW System.

Type III (and IIIA) Tanks These are tanks 25-51. The type III and IIIA tanks are the latest design of tank at SRS, and are the only tanks planned for continued service. The primary tanks are carbon steel with a design capacity of $1,300,000$ gallons. The primary tank is surrounded by a fullheight secondary tank of carbon steel, which is surrounded by a concrete vault. These tanks meet all DOE and regulatory criteria. The major differences between the two tanks are 1) the type IIIA tanks have distributed cooling coils, whereas the type III tanks have no cooling coils as constructed (Coils were inserted into these tanks through the risers after construction), 2) the type IIIA tanks have an improved pattern of cooling slots between the bottoms of the primary and secondary tanks, and 3) the type IIIA tanks have the ability to detect leakage from the secondary tank. As previously noted, six of the type IIIA tanks are dedicated to In-Tank Precipitation and Extended Sludge Processing and are not part of the Storage and Evaporation process (See Chapters 6 \& 7).

Type IV Tanks These are tanks 17-24. These tanks were built before the type III and IIIA tanks. The primary tank is carbon steel, and is surrounded by a concrete enclosure that impinges on the steel with no annular space. There is a series of drainage slots in the concrete underneath the tank that leads to a leak detection sump, but there is no secondary containment. None of these tanks have cooling coils. None of the type IV tanks meet current DOE or regulatory criteria for secondary containmeat. Two of the tanks, tanks 19 and 20, have known penetrations through the primary steel liner, although no waste has been observed to leak through these penetrations. Emptying and retiring these tanks is a high priority in the HLW System.

Three type IV tanks, tanks 21, 22, and 23, will continue to be used for low-level washwaters and thus cannot be retired from service. As previousiy noted, Tank $22 \mathrm{H}$, one of the type IV tanks, is dedicated to In-Tank Precipitation service and is not part of the Storage and Evaporation process (See Chapter 6). Also, two other tanks, Tanks $21 \mathrm{H}$ and 23H, are used for receipt of ESP washwater and wastes from the Receiving Basin for Offsite Fuels and the Resin Regeneration Facility. These three tanks will continue to be used for these purposes for a number of years.

In addition to the tenks, there is associated equipment as follows:

Evaporators There are five evaporators: 242-F, 242-16F, 242-H, 242-16H, and 242-25H. The 242-F evaporator is in cold standby, and there are currently no plans to operate this evaporator again. The 242-25H evaporator is under construction (Replecement High-Level Waste Evaporator). The evaporators are all of bent-tube design, with a pot in which the waste is heated by a benttube bundle of steam coils. The pots are housed in concrete vaults for shielding and contamination control.

In operation, liquid supernate is pumped from an evaporator feed tank and is transferred to the evaporator. Within the evaporator, the supernate is heated to its boiling point, forming a vapor phase called overheads. The overheads are condensed and monitored to ensure that excessive amounts of radionuclides are not being entrained. If required, the overheads are passed through an ion exchange column to remove radioactive cesium. Following condensing and monitoring, 
the overheads are trunsferred to the ETF for further treatment. The concentrated supernate in the evaporator pot is transferred to an evaporator receipt tank.

Maintenance Facility (299-A) This is a facility for repairing failed equipment from the tank farm. Equipment entering the facility can be decontaminated by various means, including soaking in decontamination solutions. Because of its extensive decontamination capabilities, the facility allows decontamination of equipmeat to lower levels than is possible in the field. After decontamination the equipment can be repaired by personnel in protective clothing (i.e. contact maintenance rather than the remote maintenance that is normally reguired for HLW contaminated items). This facility is usually considered part of the Tank Farm, and the spent decontamination solutions from the facility are seat to the Tank Farms. However, since the maintenance facility introduces decontamination chemicals into the weste stream, it is considered a waste generator for the purposes of the PID.

Transfer Systems This includes transfer pipelines (including the interarea transfer line from $F$ to $H$ area), diversion boxes, and purmp pits.

\subsubsection{Receipt, Storage, and Aging of Waste}

The Tank Farms receive waste from a number of sources, primarily in F and $\mathrm{H}$ areas. The wastes are produced as the result of the separtion of useful products from spent aluminum-clad nuclear fuel and targets. In the Separations proceses, the waste is dissolved in nitric acid. To prevent corrosion of the carbon steel waste tanks, the waste is then neutralized with sodium hydroxide in the Separations process before it is sent to HLW Storage and Evaporation.

Neutralizing the waste produces a dark brown mixture of insoluble sludges suspended in a salt solution. The primary insoluble species are Iron, Manganese, Aluminum, and Uranium hydroxides. The primary salt constituents are the sodium salts of $\mathrm{NO}_{3}^{-}, \mathrm{NO}_{2}^{-}$and $\mathrm{OH}^{-}$.

Incoming Wastes entering the Tank Farm (Interface Stream 1) are received into a receipt tank. iny insoluble sludges in the waste settle to the bottom of the tank, forming a layer of sludge at the $b . i \mathrm{~m}$, with a clear layer of supernate (salt solution) above it. The tanks are designed to safely store this $x$ aste, incorporating a number of featurea to preveat migration of the waste and to prevent process accidents (For example, the potential for a hydrogen explosion is significantly greater if radiolytically generated hydrogen were allowed to accumulate in a tank). Safe storage of waste is controllod by the Storage and Evaporation baseline and is outside of the scope of this document except where it influences the requirements for influent streams (See "Influent streams and key process variables" below).

During storage, the waste also ages, allowing radionuclides to decay. For some radionuclides (for example, Ru-106) radioactive aging is the process planned for removing these nuclides from high-level waste.

\subsubsection{Evaporation}

Once the sludge in the waste has settled to the bottom of the tank, a region of clear supernate remains above the sludge. To reduce the cost of storage and improve the safety of storage, the supernate is evaporated to reduce its volume and mobility. Much of the supernate is reduced to solid saitcake (with some interstitial liquid). Converting the waste into salkake considerably reduces the number of tanks needed for storage and reduces the mobility of the waste, which enhances safety for two reasons: 1) the waste is less likely to leak, and 2) having the waste in solid form reduces the probability and/or consequences of many accidents analyzed in the Safety Analysis Report. 
High-Level Waste System Process Interface Description

To accomplish evaporation, the supernate in a waste receipt tank is decanted and sent to an evaporator. The supernate may be sent directly from the waste receipt tank to an evaporator (i.e., the waste receipt tank doubles as an evaporator feed tank) or may be sent to a designated evaporator feed tank.

The overheads from the evaporator are condensed, creating a mildly contaminated wastewater stream. After condensation, the overheads are sent to a mercury collection tank. Overbeads from HLW with high mercury concentrations are supersaturated in mercury (because mercury is volatile), so small quantities (liters per week or less) of mercury collect in the bottom of the tank. Any mercury that is collected (many wastes produce no mercury) is recycled to the Separations processes. This is a lowvolume, intermittent stream that is managed as part of the Storage and Evaporation technical baseline.

After passing through the mercury collection tank, the overheads may be treated by passing them through a cesium removal column (an ion exchange column) to remove residual $\mathrm{Cs}-137$. This treatment step is omitted for overheads that have been sufficiently decontaminated by the evaporator.

Once all treatment steps in the evaporator system are completed, the overbeads are sent to ETF (Interface Stream 13) for further decontamination and eventual release to the environment.

The concentrated evaporator bottoms are sent to an evaporator receipt tank. In the receipt tank, the concentrated waste cools, and solid salt crystallizes and deposits on the floor, cooling coils, and wall of the receipt tank. The concentrated salt solution left in the receipt tank is then transferred back to the evaporator feed tank for further evaporation.

The goal of this process is to concentrate most of the salt solution into solid saltcake, which minimizes the volume and eahances the safety of storing the salt waste.

\subsubsection{Waste Removal}

Once the downstream processes-Extended Sludge Processing and In-Tank Precipitation-are ready to receive waste from a particular tank, the waste is removed from the tank using hydraulic slurrying techniques.

Waste removal from a tank includes the following processes:

- Waste removal (sludge or salt) using long-shafted slumy pumps to agitate the liquid contents of the tank and suspend the sludge or dissolve the salt. Waste is pumped out of the tank using a pump or jet.

- Spray washing of the tank using rotary spray jets with hot water. The contents of the tank are then agitated with slurry pumps and pumped out of the tank.

- Annulus cleaning of takiks that have leaked using steam and hot water.

Once these processes have been completed on a tank, waste removal from the tank is complete. If there are no plans for future operation of the tank, then the tank must then be decommissioned and closed. 


\subsubsection{Decommissioning and Closure}

Once Waste Removal has been completed in a tank, the tank leaves the HLW System, and responsibility for the tank changes to SRS organizations responsible for docommissioning and closure These activities are outside the scope of the PID.

Although various options for closing of waste tanks bave been proposed, at this time there is no accepted method of closing a waste tank. The leading candidate at this time is to fill the tank with clean grout to prevent subsidence, then close the tank and immediately surrounding land as a landfill. SRS is currently studying this method of closure for Tank $16 \mathrm{H}$, an older waste tank from which waste removal has been completed. Tank $16 \mathrm{H}$ is the subject of a RCRA Facility Investigation, and so is being actively discussed among DOE, EPA, SCDHEC, and WSRC.

Closure of waste tanks might require further cleaning than possible with the waste removal processes. For example, during waste removal from Tank $16 \mathrm{H}$, the tank was spray washed with hot oxalic acid. which resulted in better cleaning than spray washing with hot water. Depending on the results of the Tank 16H RCRA Facility Investigation and other studies, the decision may be made to use oxalic acid cleaning or other aggressive cleaning methods as part of closure of the tanks. However, none of these cleaning methods are within the scope of the Process Interface Description. The problem with most chemical cleaning methods is that they introduce large quantitics of water or chemicals (either new chemicals or larger quantities of existing chemicals) that must then be managed throughout the high-level waste system.

\subsection{Influent Streams and Key Process Variables}

\subsubsection{Sources}

HLW Storage and Evaporation receives Incoming Wastes from a number of sources, including but not limited to the following:

Interface Stream 1: Incoming Wastes from

- F-Canyon (Separations, including outside facilities)

- H-Canyon (Separations, including outside facilities)

- The Receiving Basin for Offsite Fuels (RBOF) and the Resin Regeneration Facility (RRF) (These two facilities are located in the same building, and the waste from them is often mixed before transfer to Storage and Evaporation)

- Reactor Areas

- Savannah River Tochnology Center (SRTC)

- Analytical Leboratory facilities

- Other site facilities 
- Waste generated from decommissioning of tanks or other facilities

The HLW Stonge and Evaporation process receives the following recycle streams from within the HLW System

Interface Stream 1: Spent decontamination solutions from the Tank Farm Maintenance Facility (299-H) Interface Stream 3: Spent Washwater from Sludge Processing

Interface Stream 10: Recycle from the Defense Waste Processing Facility (DWPF)

Interface Stream 19: Highly Contaminated Cooling Water or Storm Water

Interface Stream 20: Highly Contaminated ETF Concentrate

In addition to these streams, Storage and Evaporation also receives many internally generated streams. However, these streams are controlled by the Storage and Evaporation baseline and are not described in detail in this document.

\subsubsection{Requirements}

This section describes the requirements for acceptance of waste into the Storage and Evaporation. All of the streams mentioned in the previous section are received into waste tanks for storage and are subject to the same requirements except where specified below.

The parameters of concern in receiving waste into Storage and Evaporation are shown in table 4-1. The HLW Waste Acceptance Criteria (WAC) ${ }^{2}$ gives more information on what characterization must be performed on any particular waste. 


\section{Table 4-1 \\ Storage and Evaporation Influent Parameter List}

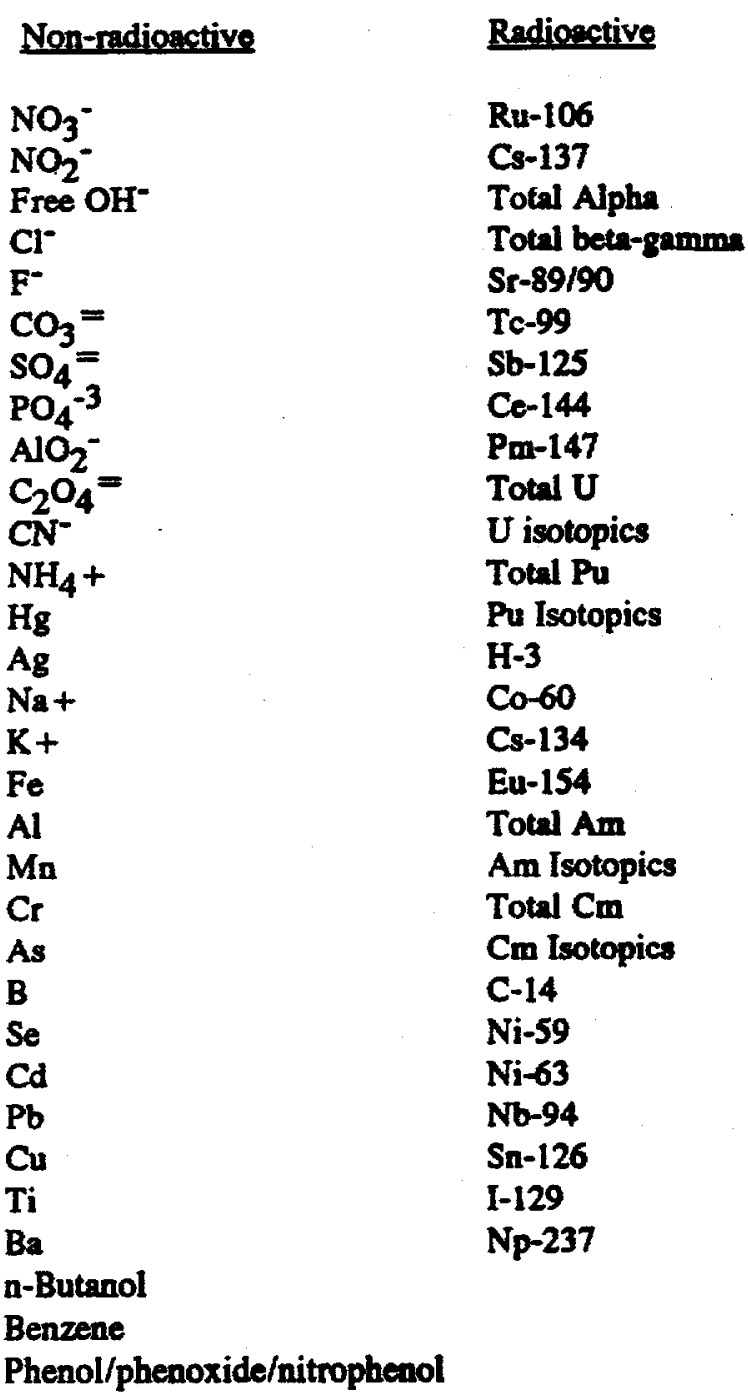

Characteristics

Total Insoluble Solids

Specific Gravity

Total Organic Carbon

Total Dissolved Solids

$\mathrm{pH}$

Known volatiles $>20 \mathrm{ppm}$

Known chelating agents

\subsubsection{Requirements for Cormosion Prevention}

The HLW storage tanks and cooling coils within the tanks are composed of carbon steel and are susceptible to general corrosion, nitrate induced stress corrosion cracking, and pitting corrosion.

Waste solutions to be transferred into Storage and Evaporation must be alkaline and must be inhibited to prevent corrosion of carbon steel. Also, concentrations and volumes of incoming wastes must be controlled so that when two or more incoming wastes are combined in a waste tank the resultant mixture is also within limits. Corrosion limits are specified in the Tank Farm Waste Acceptance Criteria."

The High-Level Waste Engineering Support Group meets with all routine generators on a quarterly basis and sets specific limits for individual generators, as appropriate, to ensure that controls are adequately maintained. These limits are documented in meeting minutes for these meetings. In the future, each generator will be required to develop $\&$ Waste Compliance Plan describing the waste composition controls. 
Special streams are reviewed case-by-case by the High-Level Waste Engineering Support Group.

\subsubsection{Requirements for Prevention of Accumulation of Flammable and Explosive Components}

Ammonia: In the presence of freo hydroxide ammonium nitrate forms ammonium hydroxide, evolving ammonia gas, which is flammable at greater than 14.5 vol $\%$ in dry air. To ensure that the ammonia concentration does not exceed flammable limits, the Tank Farm Waste Acceptance Criteria ${ }^{8}$ limits the concentration of ammonium nitrate in wastes received in the Tank Farm to $2.5 \mathrm{wt} \%$, with a maximum rate of receipt of $1000 \mathrm{~kg}$ per 12 hours. Receipts that are high in ammonia are unusual transfers that must be reviewed case-by-case or in quarterly meetings with routine generators. In the future, compliance with this requirement will be documented in generator Wasto Compliance Plan(s).

Organic Compounds: Organics entering the Tank Farm have the potential to float to the surface of the aqueous waste and present a fire or explosion hazard. To control this hazard, the concentration of all organics entering the Tank Farm is limiled to 0.5 vol\% insoluble organics (determined by freon extraction)." In addition, highly volatile organics (e.g., benzene) are controlled to lower limits to prevent the formation of flammable vapors. Currently, this limit is controlled by discussions in quarterly meetings or case-by-case evaluations of special waste streams. In the future, compliance with this requirement will be documented in generator Waste Compliance Plan(s).

Shock Sensitive Compounds: In 1970, popping noises were heard when dried waste deposits in the tank 21 feed jet enclosure and the 242-H evaporator cell were disturbed by personnel and/or equipment. Investigation of the incident revealed that silver was present in the waste feeding the evaporator and probably formed silver nitride, a shock sensitive compound. The silver was present due to flushes of the silver coated Berl saddles used in the canyons to remove I-129. To control this hazard, the Tank Farm Waste Acceptance Criteria specifies that no waste may be received into the Tank Farms that contains silver, except for silver present as a fission product and small quantities from laboratory and/or analytical methods." This requirement was instituted in $1970^{\circ}$ and has successfully prevented further incidents. Currently, this limit is controlled by discussions in quarterly meetings or case-by-case evaluations of special waste streams. In the future, compliance with this requirement will be documented in generator Waste Compliance Plan(s).

\subsubsection{Cs-137 Concentration in Waste Transferred to Type IV Tanks}

The Tank Farm Waste Acceptunce Criteria limits the concentration of waste transferred into type IV tanks to 0.6 Curies per gallon of Cs-137. The purpose of this limit is to reduce the risk of leakage. The type IV tanks have no secondary containment, so the probability that leakage from a type IV tank will reach the environment is higher than for a leaking primary on the other types of tanks. The purpose of the control is to limit the consequence of leakage, so that the total risk (probability times consequence) is acceptable.

Under emergency conditions, there is the potential that one generator, the Receiving Basin for Offsite Fuels (RBOF), may need to send waste that exceeds this limit to type IV tanks. Waste from RBOF is normally received into Tanks $21 \mathrm{H}$ and $23 \mathrm{H}$, which are type IV tanks. The waste is normally low-level, but there are potential accidents that could cause the radioactivity in the reactor fuels stored in the basin to be released into the basin water, creating a large quantity of contarninated water. Under such emergency conditions, the waste would be accepted into Tanks $21 \mathrm{H}$ and $23 \mathrm{H}$ but would be transferred out as soon as possible to reduce the risk of leakage from the tanks.

This limit is controlled by discussions in quarterly meetings with routine generators and case-by-case evaluations for special streams. In the future, compliance with this requirement will be documented in generator Waste Compliance Plan(s). 


\subsubsection{Rexuiremente for Requitory Complince}

No RCRA listed hezandous wastes (i.e., wnstes listed in the subpart D lists of 40 CFR 261) may be received into the Taak Farm." Characteristically hazardous wastes (Subpart C wastes) are acceptable for the characteristics listed in Tank Farm permits and regulatory agreements (such as the Federal Facility Compliance Agreement)."

The prohibition on acceptance of RCRA listed hazardous waste is imposed to ensure that any waste received into Storage and Evaporation can be processed through downstream processes. Reviews of waste currently in storage have shown that no listed wastes have historically been sent to the tank farm. Although small quentities of laboratory chemicals on the hazardous waste lists huve been received in the Tank Farms, in all cases the disposal of these chemicals was covered by various RCRA exemptions and did not generated a listed hazardous waste. ${ }^{10,11,12}$

Although the Tank Farm permits allow receiving listed hazandous wastes, the permits for DWPF Glass and Saltstone, which will process all the wastes from the Tank Farms, do not allow processing of listed hazardous wastes. This is because DWPF, Saltstone, and ETF are permitted to produce only nonhazardous products (glass, Saltstone, and treated water, respectively). EPA and SCDHEC regulations specify that any products derived from a listed waste are also considered hazardous waste.

It would be possible to receive a listed hazardous waste in the Tank Farm, but oniy if the glass, Saltstone, and treated water effluents from DWPF Glass, Saltstone, and ETF were formally delisted following approved EPA protocols. Such a delisting is a lengthy regulatory procese.

This limit is controlled by discussions in quarterly meetings with routine generators and case-by-case evaluations for special streams. In the future, compliance with this requirement will be documented in generator Waste Compliance Plan(s).

\subsubsection{Requirements for Criticality Safety}

Waste received in the Storage and Evaporation must be sufficiently low in fissile material concentration or sufficiently high in neutron poisons to prevent a criticality. The concentrations in any incoming waste must be sufficient to prevent a criticality in infinite geometry, and under all conditions to which the waste will be subjected during further processing in evaporation, In-Tank Precipitation, and Extended Sludge Processing (Washing and Aluminum Dissolution). The limits on receipt into Storage and Evaporation are the primary criticality control for these processes. Note that this limit specifically does not address DWPF, because the DWPF processes have the potential to concentrate fissile material. Therefore, criticality safety in tho DWPF is addressed separately.

This criticality safety requirement is administered by the High-Level Waste Engineering Support Group. This group has the responsibility of 1) preparing nuclear criticality safety analyses for all wastes routinely accepted into tho Storage and Evaporation, and 2) reviewing and approving the receipt of any waste not routinely accepted. Administrative controls requiro a nuclear criticality safety analysis for any new waste not bounded by an existing nuclear criticality safety analysis.

\subsubsection{Requirements for SAR Source Term Comparison}

The Tank Farm SAR contains tables of source terms--assumed concentrations of radionuclides in Storage and Evaporation wastes. These source terms are used in SAR accident analysis and are part of the authorization basis for Storage and Evaporation. The Tank Farm Wasto Acceptance Criteria' requires 
that incoming wastes must be within the concentrations specified in the Tank Farm SAR source terms, or the discrepancy must be addressed via an Unreviewed Safety Question Determination.

This limit is controlled by discussions in quarterly meetings with routine generators and case-by-case evaluations for spocial streams. In the future, compliance with this requirement will be documented in generator Waste Compliance Plan(s).

\subsubsection{Requirements to Satisfy ETF Feed Bases}

The concentration of volatile species in wastes accepted into Storage and Evaporation must be within appropriate limits so that the evaporator overheads can be produced that will meet ETF acceptance criteria.

This limit is controlled by discussions in quarterly meetings with routine generators and case-by-case evaluations for special streams. In the future, compliance with this requirement will be documented in generator Waste Compliance Plan(s).

\subsubsection{Requirements to Satisfy Saltstone Waste Acceptance Criteria}

The concentration of wastes accepted into Storage and Evaporation must be within appropriate limits so that decontaminated supernate can be produced that will meet Saltstone Waste Acceptance Criteria. ${ }^{13}$ it is acceptable to receive limited quantities of waste outside these limits, as long as the quantities are controlled such that this waste can be blended with other wastes that are inside the limits. Acceptance of controlled quantities of waste outside the Saltstone limits must be reviewed and approved on a case-bycase basis.

This limit is controlled by discussions in quarterly meetings with noutine generators and case-by-case evaluations for special streams. In the future, compliance with this requirement will be documented in generator Waste Compliance Plan(s).

\subsubsection{Requirements to Satisfy DWPF Glass Feed Desion Basis}

The concentration of wastes accepted into Storage and Evaporation must be within appropriate limits so that washed sludge from ESP and precipitate from In-Tank Precipitation are produced that will meet the DWPF Feed Design Bases. ${ }^{14}$

This limit is controlled by discussions in quarterly meetings with routine generators and case-by-case evaluations for special streams. In the future, compliance with this requirement will be documented in generator Waste Compliance Plan(s).

\subsubsection{Requirements to Satisfy ITP SAR addendum Basis}

The concentration of wastes accepted into Storage and Evaporation must be within appropriate limits so that salt solution can be produced that will meet the ITP SAR addendum limits. ${ }^{15}$

This limit is controlled by discussions in quarterly meetings with routine generators and case-by-case evaluations for special streams. In the future, compliance with this requirement will be documented in generator Waste Compliance Plan(s). 


\subsection{Effluent Streams and Key Process Controls}

\subsubsection{Sludge to ESP--Interface Stream 2}

In the Tank Farms, sludge is composed of the insoluble compounds that settle to the bottom of waste receipt tanks. To remove the sludge from the tanks, water or dilute waste is added to the tank and the sludge is suspended using long-shafted slurry pumps. After slurrying, the slurrying is pumped to one of the tanks dedicated to sludge processing (Tanks $40 \mathrm{H}, 42 \mathrm{H}$, und SIF).

Most of the sludge that will be processed through the High-Level Waste System already exists in the Tank Farms, having been deposited in over $\mathbf{4 0}$ years of SRS operation. Variations in the composition of the sludge have the potential to impact DWPF operation.

The DWPF is designed so that it can process sludge that is within the range of the normal PUREX and HM processes that have been historically used in the SRS canyons, ${ }^{16}$ so there is minimal concern with processing most of the wastes. However, high-heat wastes contain high concentrations of radionuclides, which have the potential to impact DWPF operation. Also, small quantities of unusual wastes exist in storage that are significantly different in composition from those normally produced by these processes, mostly from special campaigns. This waste has the potential to negatively impact DWPF operation if not sufficiently mixed with other wastes. Information about this these special campaign wastes is limited.

To ensure acceptable operation of the entire HLW System, the composition of each batch of sludge is forecasted in advance of processing, using sample data and process knowledge. Once each batch is assembled in the processing tanks, it is then sampled and analyzed to confirm that the composition is acceptable. During each step (forecasting or sampling and analysis in the processing tanks) the potential exists that pockets of waste may be identified that are unacceptable. In such cases, it may be desirable to blend the waste from tanks that are high in a particular component with wastes from tanks that are low in that component. Or it may be neceseary to adjust processing conditions in HLW Processes. In any case, anticipating the composition of the waste is needed to avoid unintended disruptions to operation of HLW processes. The High-Level Waste System Plan documents the planned batches in which the waste is to be removed from tanks and sent to Extended Sludge Processing.

The process for modifying the High-Level Waste System Plan is described in more detail in the section on "DWPF Feed Acceptence."

\subsubsection{Salt Solution to ITP--Interface Stream 5}

The salt solution sent to In-Tank Precipitation comes from two sources: 1) saltcake that has been dissolved using water or dilute waste and long-shafted slurry pumps, and 2) supernate in Storage and Evaporation that has not been converted into saltcake.

Similar to sludge, most of the salt waste already exists, and its composition can no longer be adjusted. Variations in the composition of salt have the potential to impect ITP, DWPF Saltstone, or DWPF Vitrification. Thus, the composition of each batch of salt solution is forecasted in advance of processing using samples and processes knowledge, as is done for sludige. Once each batch is assembled in the processing tanks, it is then sampled and analyzed to ensure that the composition is acceptable. The HighLevel Waste System Plen documents this batch scheme by describing the order in which the waste is to be removed from tanks and sent to In-Tank Precipitation.

The process for modifying the High-Level Waste System Plan is described in more detail in the section on "DWPF Feed Acceptance." 


\subsubsection{Evaporator Overheads-Interface Stream 13}

The overheads from the evaporators are sampled, analyzed, and then transferred to the ETF if within limits. The key parameter that is controlled is the concentration of Cs-137.

There is also a requirement that the overheads be in accordance with the limits in the ETF permit. However, given the composition of the existing wastes in Stornge and Evaporation, experience has shown that the current limits on Cs-137 for evaporator overheads are sufficient. ${ }^{17}$

If new constituents are added to the Storage and Evaporation, most notably volatile constituents that could go overhead in significant concentrations, consideration must be given to establishing additional controls.

\subsubsection{Storm Water Runoff (Clean and Diverted)-Interface Stream 17}

Storm water runoff from the Storage and Evaporation tanks is sent directly to a NPDES outfall after the online monitor determines that it is not radioactively contaminated. If the monitor detects contamination, or for any of several administrative/precautionary reasons, the stormwater can be diverted to the ETF basins, as described in "9.2.2. Diverted Water Besins." 


\section{SALT PROCESSING (IN-TANK PRECIPITATION)}

\subsection{Function}

The In-Tank Precipitation (ITP) process treats the salt solution from HLW Storage and Evaporation to remove radionuclides so that the salt solution can be disposed of in Saltstone. The removed radionuclides are concentrated in an organic precipitate that is washed and sent to the DWPF Late Wash Facility.

\subsection{Description of In-Tank Precipitation}

\section{ITP Procese}

In the ITP process, soluble radioactive metal ions-cesium, strontium, uranium, and plutonium-are precipitated with sodium tetraphenylborate or adsorbed on Monosodium titanate to form insoluble solids. The resulting precipitate, which contains most of the radionuclides, is filtered to concentrate the solids. The precipitate is sent to the DWPF for vitrification in glass. The decontaminatod salt solution, or filtrate, containing primarily sodium salts of hydroxide, nitrate, and nitrite, is transferred to Saltstone for disposal. ITP is sized to process the contents of approximately one tank (about $1,000,000$ gallons of salteake) of HIW saltcake per year.

The concentrated precipitate is wasbed with inhibited water (well water with corrosion inhibitor chemicals) to reduce the soluble salt content. As a result, the mass of constituents that must be incorporated in the DWPF glass is significantly decreased by the ITP process, reducing the volume of glass produced and the disposal costs.

The low-activity, decontaminated filtrate from the concentration process is processed through a stripper column to remove benzene generated from radiolytic decomposition of tetraphenylborate. Benzene removal from salt solution is required because of flammability concerns in Tank $50 \mathrm{H}$ and leachability of benzene from the Saltstone. The benzene-stripped salt solution is transferred to Tank $50 \mathrm{H}$ and disposed of in Z-area Saltstone.

The filtrate generated by washing the high-activity precipitate is passed through a stripper column and is temporarily stored in Tank $22 \mathrm{H}$ for recycle into subsequent cycles. This wash water can have a radioactivity level higher then decontaminated salt solution due to the dissolution of CsTPB during washing and may not be processed in Saltstone. Benzene is stripped from this filtrate to meet the limits for Tank $22 \mathrm{H}$ flammability. 


\section{Figure 6-1: In-Tank Precipitation}

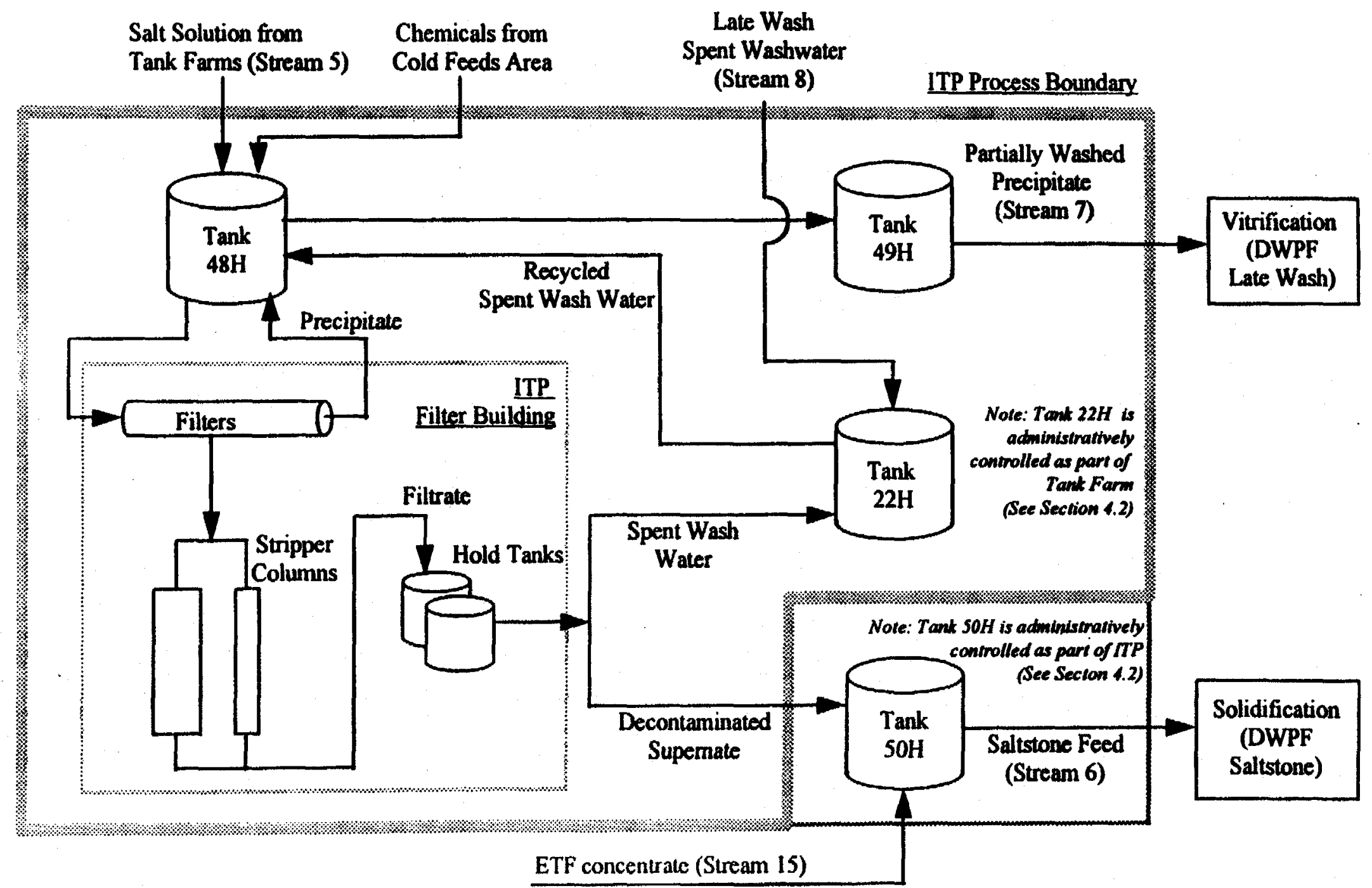




\section{In-Tank Precipitation Equipment}

In-Tank Precipitation (Figure 6-1) includes and interfaces with the following equipment:

Tank 48H - This Type IIA tank is the location of the precipitation and absorption reactions. This nitrogen-inerted tank is equipped with filter foed pumps and slurry pumps for agitation.

Tank 49H - This nitrogen-inerted Type IIIA tank stores washed precipitate and serves as the feed tank for the Late Wash.

Tank 50H - This Type IIIA tank stores decontaminated salt solution and ETF Concentrate prior to disposal in Saltstone. This tank functions as a feed tank for Saltstone but is administratively controlled as part of the ITP.

Tank 22H - This Type IV tank is used to store speat wash water from both ITP and Late Wash. This tank is administratively part of the Storage and Evaporation process but functions as part of the ITP process.

Filter/Stripper Building - This facility houses the two crossflow filters used for concentration of the precipitate, as well as the two stripping columns used to remove benzene. The filters are sintered stainless-steel tube bundles with a submicron pore size. The strippers are packed columns in which nitrogen is used to strip benzene from the filtrate. The Filter/Stripper Building also contains tanks, piping, valves, and instrumentation to support the process, as well as a process control laboratory.

ITP Control Building - This building bouses the Instrument Control Room and the Electrical Control Room.

Cold Feeds Area - This area contains tanks, pumps, piping, and instrumentation necessary to receive, store, and add nonradionctive reagents to the process.

Diversion Boxes 2, 5, and 7 - These boxes are used to transfer solutions and slurries between tanks.

\subsubsection{Decontamination and Concentration Process}

Salt solution is pumped into Tank 48H from Storage and Evaporation. The salt solution is decontaminated in a batch process where it is mixed with inhibited water or recycled wash water from Tank 22H, sodium tetraphenylborate (NaTPB), $\mathrm{NaB}\left(\mathrm{C}_{6} \mathrm{H}_{5}\right)_{4}$, and mono-sodium titanate (MST), $\mathrm{NaTi}_{2} \mathrm{O}_{5} \mathrm{H}$. The purpose of the inhibited water or recycled wash water is to reduce the total sodium content to within the range necessary to optimize the precipitation reaction. The most abundant radionuclide present in salt solution is Cs-137. Sodium tetraphenylborate is added to precipitate the cesium as a tetraphenylborate salt. The non-radioactive potassium, cesium, and ammonium ions are also precipitated in this process. The potassium ion concentration is normally 100 times that of the total cesium concentration, although this ratio can vary widely.

$\mathrm{M}^{+}+\mathrm{B}\left(\mathrm{C}_{6} \mathrm{H}_{5}\right)_{4}^{-} \Rightarrow \mathrm{MB}\left(\mathrm{C}_{6} \mathrm{H}_{5}\right)_{4} \quad\left(\mathrm{M}=\mathrm{Cs}, \mathrm{K}\right.$, or $\left.\mathrm{NH}_{4}\right)$

Mercury also reacts with tetraphenylborate to form insoluble diphenylmercury which is retained in the precipitate during filtration. An excess of NaTPB is added to enhance the decontamination of cesium. 
Monosodium titanate is added to adsorb the soluble strontium, plutonium, and uranium ions if present in quantities exceeding the limit in Saltstone.

The concentration of the slurry, containing the MST and precipitated tetraphenylborate solids, is a nominal $1 \mathrm{wt} \%$ insoluble solids after precipitation. The slurry is concentrated by crossflow filtration to a nominal $10 \mathrm{wt} \%$ and is returned to Tank 48H. This series of steps (waste transfer, inhibited water and chemical addition, and filtration) is repeated as necessary to obtain an acceptable amount of concentrated slurry for the washing stage.

\subsubsection{Precipitate Washing Process}

The combined slurry from one or more batches is then washed to remove soluble sodium salts by adding inhibited water to Tank $48 \mathrm{H}$ and removing spent wash water by filtration. The spent wash water is transferred to Tank 22H for recycling in subsequent batches as dilution water. Excess sodium tetraphenylborate is also removed in this procedure, and is similarly recycled in subsequent batches. The high-activity washed precipitate is transferred to an interim storage tank, Tank $49 \mathrm{H}$, prior to transfer to the DWPF Lato Wash .

When necessary, the filters are chemically cleaned to remove foulants from the surface during either the washing or concentration procesess. The cleaning chemicals are oxalic acid solution and sodium hydroxide solution. The waste solutions generated by this cleaning are sent to Tank $\mathbf{4 8 H}$.

\subsubsection{Benzene Removal Process}

The filtrate solutions are processed through the benzene stripping columns located in the ITP Filter/Stripper building. The two columns are designed for different flow rates with the larger column for the decontaminated salt solution and the smaller column for spent wash water. Using separate columns for the processes improves contumination control by segregating the higher activity spent wash water from decontaminated salt solution. Benzene is present in the sodium tetraphenylborate and is also produced from radiolysis of the precipitate in the tank. The counter-current nitrogen gas phase in both columns passes through a High Efficiency Particulate Air (HEPA) filter system prior to venting to the atmosphere. The liquid exiting the columns is collected in filtrate hold tanks, sampled, and analyzed prior to release to Tank 5OH (decontaminated salt solution) or Tank 22H (spent wash water).

\subsection{Influent Streams and Key Process Variables}

\subsubsection{Sources}

The influent to the ITP process is salt solution from Storage and Evaporation (Interface Stream 5), spent wash water from Late Wash (Interface Stream 8), and ETF concentrate into Tank 50H (Interface Stream 15). The origin of the waste contrined in the salt solution is discussed in Section 4.3.1. The salt removal process is discussed in Section "5.4.2. Salt Solution to ITP-Interface Stream 5."

\subsubsection{Requirements}

The composition of the salt solutions transferred to ITP must be within certain limits to ensure both safety and efficiency of the operation. The ITP OSRs ${ }^{18}$ and Process Requirements ${ }^{19}$ establish specific limits for key species. The composition of the spent wash water from Late Wash must also meet the criteria listed in the Process Requirements. 


\subsubsection{Requirements for Corrosion Prevention}

ITP Tank 48H, which receives incoming wastes to ITP, is constructed of carbon steel. Thus, any incoming wastes must be inhibited with corrosion-inhibiting chemicals. Inhibitor limits are controlled by the ITP-OSR.

\subsubsection{Tank $48 \mathrm{H}$ Influent Composition Safety Requirements}

The composition of the salt solution transferred into Tank 48H must be known. Radionuclide composition must be confirmed to be within the ranges evaluated in the ITP SAR Addendum is and Tank Farm SAR. ${ }^{20}$ Any discrepancy must be sddressed vis an Unreviewed Safety Question Determination. Vapor flammability and several sccident scenarios involving solida fires and natural disasters are evaluated in the ITP SAR Addendum. ${ }^{15}$ Radionuclide composition of the waste in ITP is bounded by the levels evaluated in theso scenarios.

The time for the vapor space gases to reach the Lower Flammability Limit (LFL), coupled with the need for spare tank capacity, dictate the tank fill limits in both Tank $48 \mathrm{H}$ and Tank $49 \mathrm{H}$ (ITP OSR ${ }^{13}$ ). Vapor flammability concerns arise due to the decomposition of tetraphenylborate and radiolysis of water which generates benzene and hydrogen, respectively. Ventilation and nitrogen purging of the tanks decreases the flammability risk. However, a 3-day allowance to restore ventilation following a lose-of-ventilation event requires that a specified volume of space be available for vapor accumulation. The fill limit for the tank is defined such that the calculated time to LFL is more than the 3-day criterion, including the spare tank capacity allotment.

\subsubsection{Tank 22H Feed Requirements--Interface Stream 8}

The Tank Farm Technical Standards ${ }^{21}$ and the ITP Process Requirements" dictato that Type IV tanks receive only solutions contrining less than $0.6 \mathrm{Ci} / \mathrm{gal}$ of Cs-137 activity. Solutions generated during the Late Wash and ITP wash cycles must meet this requirement." Flammability controls on Tank 22H influent, as deacribed in the ITP Safety Analysis Report, ${ }^{15}$ apply to spent wash water from Late Wash.

\subsubsection{Tanks $48 \mathrm{H}$ and $49 \mathrm{H}$ Criticality Safety Requirements}

Administrative criticality safety requirements for the ITP process are listed in the ITP OSR. ${ }^{18}$ The influent waste stream from Storage and Evaporation is sampled and analyzed to ensure compliance with the administrative control requirement.

\subsubsection{Requirements to Satisfy Saltstone Feed Requirements--Interface Streams 5 and 15}

Saltstone Feed Requirements are listed in the ITP Process Requirements. ${ }^{19}$ After considering dilution, blending, precipitation, and adsorption which occur in ITP, influent to ITP must permit decontaminated salt solution to meet concentration requirements for Saltstone after the stream is mixed with ETF concentrate in Tank 50H. The Saltstone influent species currently controlled by the ITP Process Requirements are listed in Table 6-1. The waste contains other species not listed, which is expected, but the addition of species not listed in Table 6-1 requires re: iew and approval (See " 2.3. Changes to Process Interface Description"). 


\section{Table 6-1 \\ ITP Influent Parameter List}

\begin{tabular}{|c|c|c|}
\hline 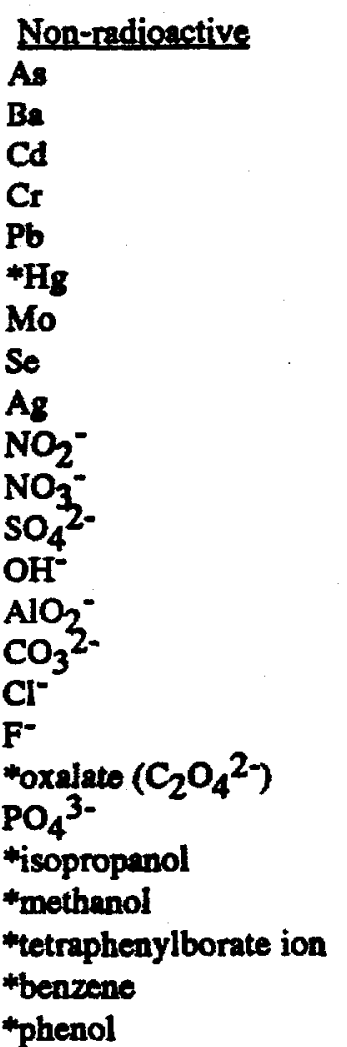 & 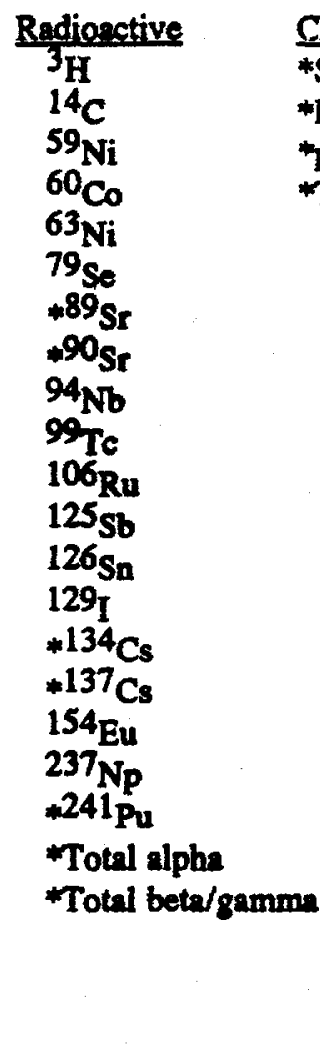 & $\begin{array}{l}\text { Chanacteristics } \\
\text { * Specific gravity } \\
\text { *Insoluble Solids } \\
\text { "pH } \\
\text {-Temperature }\end{array}$ \\
\hline
\end{tabular}

* Concentrations of these species are modified within ITP

Variability in the salt solution influent will be controlled by blending salt solutions to the extent possible (see "4.2. DWPF Feed Acceptance"). The reasons for establishing waste acceptance criteria for these constituents are described in Section "10.3. Influent Stream and Key Process Variables-Interface Stream 6."

Methanol and isopropanol are present in smal] quantities in the monosodium titanate slurry as a result of manufacturing process. The benzene and phenol are present as radiolytic and chemical degradation products of tetraphenylborate. Benzene is removed in the stripper column. Tetraphenylborate concentration is controlled by the inherent low solubility of the ion in salt solution.

The $\mathrm{pH}$ and specific gravity are partially controlled by the degree of dilution to reach the appropriate sodium ion concentration. The temperature is manipulated by pump operation cycling and cooling coils. The insoluble solids are virtually all removed by the crossflow filters.

Mercury ions react with tetraphenylborate ion to form diphenylmercury. The diphenylmercury is insoluble and is retained in the slurry phase sent to Tank $49 \mathrm{H}$. Oxalate ion is added to Tank $48 \mathrm{H}$ during the ITP processing as a result of filter cleaning. Oxalate ion is also present in the recycled spent wash water received from Tank $22 \mathrm{H}$ due to filter cleaning in Late Wash and radiolytic degradation of TPB. Both mercury and oxalate ion are controlled by the ITP Process Requirements ${ }^{19}$ and limited by their inherently low solubility in sait solution. 
The radianctive cesium, stroatium, and plutonium are removed in the ITP process and have much higher allowrble influent concentrations for Tank 48H than for Saltstone. The concentrations of sodium, potassium, cesium, and strontium dictato the quantities of inhibited water, sodium tetraphenylborate, and monosodium titanate to be added to satisfy the Saltstone limits.

The remaining non-radioactive and radioactive species present are limited in Saltstone due to regulatory, ALARA, or Saltstone durability concerns (see Section 9.3). These constituents are unaffected by the ITP process other than by the dilution associated with addition of inhibited water and chemical reagents. The concentrations of these species and the composition of ETF concentrate are controlled by the ITP Process Requirements. ${ }^{19}$

\subsubsection{Requirements to Satisfy DWPF Feed Bases-Interface Stream 7}

The effects and impacts of the components listed in Table 6-2 are discussed in the DWPF Feed Design Bases. ${ }^{14}$ The interface control document for the influent to ITP is the Process Requirements ${ }^{19}$ which address the acceptable salt solution composition. These requirements ensure that salt solution received from Storage and Evaporation will result in the production of acceptable concentrated slurry in ITP (see Section "8.4.1.1. Precipitate Feed to the LWF-Interface Stream 7").

\section{Table 6-2}

\section{DWPF Precipitate Feed Design Bases Component List}

Non-radioactive

$\begin{array}{ll}\mathrm{Na} & \mathrm{NO}_{2}^{-} \\ \mathrm{Ti} & \mathrm{NO}_{3}^{-} \\ \mathrm{B} & \mathrm{SO}_{4}^{2-} \\ \mathrm{K} & \mathrm{Cl}^{-} \\ \mathrm{Mn} & \mathrm{F}^{-} \\ \mathrm{Cr} & \text { flammable organics } \\ \mathrm{P} & \text { tetraphenylbonte ion } \\ \mathrm{Cu} & \text { Total insoluble solids } \\ \mathrm{H} & \end{array}$

\section{Radioactive}

${ }^{90} \mathrm{Sr}$
$106 \mathrm{Ru}$
$134 \mathrm{Cs}$
$137 \mathrm{Cs}$
$238 \mathrm{Pu}$
$239 \mathrm{Pu}$
$240 \mathrm{Pu}$
$241 \mathrm{Pu}$
$241 \mathrm{Am}$
$242 \mathrm{~m}$
$244 \mathrm{Am}$
$245 \mathrm{Cm}$

\subsubsection{Raw Materials}

The following chemicals are used as either process chemicals or cleaning reagents. The specifications for each of these species is controlled by the applicable purchrse specification.

NaTPB Sodium tetraphenylborate for precipitation

MST Monosodium titanate for radionuclide adsorption

$\mathrm{NaOH} \quad$ Sodium hydroxide for corrosion control and filter cleaning

$\mathrm{H}_{2} \mathrm{C}_{2} \mathrm{O}_{4} \quad$ Oxalic acid for filter cleaning

$\mathrm{N}_{2}$ Nitrogen gas for inerting tanks and benzene stripping

$\mathrm{NaNO}_{2}$ Sodium nitrite for corrosion control in tanks 


\subsection{Effluent Streams and Key Process Controls}

\subsubsection{Decontaminated Supernate to Saltstone--Interface Stream 6}

Composition of ITP effluent to Saltstone is controlled by the ITP Process Requirements ${ }^{19}$ and the HighLevel Waste System Plan.' The ITP process reduces the concentration of several species in the salt solution to levels acceptable within Siltstone. Those species which are not affected by the ITP process are controlled by the High-Level Waste System Plan. The volums of decontaminated salt solution transferred into Tank 50H is controlled by the ITP Process Requirements, which includes a tankage allowence for ETF operations.

\subsubsection{Precipitate to Late Wash--Interface Stream 7}

Washed precipitate is produced within ITP and is transferred to Tank $49 \mathrm{H}$ where it remains until it is processed in Late Wash and DWPF. The influent to ITP must be of a composition which allows ITP to precipitate, filter, and wash the slurry such that the accumulated material in Tank $49 \mathrm{H}$ is acceptable to DWPF when received. Tank 49H will always contain material from more than one cyclo of ITP, so some credit can be taken for the blending that will occur. The interfece control document is the ITP Process Requirements ${ }^{19}$ which will permit production of slurry to meet the requirements of the DWPF Feed Design Bases. ${ }^{14}$

The insoluble solids level in the precipitate must be sufficiently concentratod to permit chemical processing in DWPF, and the compounds which are incompatible with glass must be removed. The precipitate is washed in ITP until the concentration of soluble species are at acceptable levels for Late Wash. Corrosion inhibitors are added to the procipitate during the washing phase and in Tank $49 \mathrm{H}$. Multiple batches of washed precipitate are stored in Taak 49H and are blended with slurry pumps prior to transfer to Late Wash.

\subsubsection{Diverted Storm Water to ETF--Interface Stream 17}

Storm water runoff from the ITP tanks is sent directly to a NPDES outfall after the online monitor determines that it is 'clean'. If the monitor detects contamination, or for any of several administrative/precautionary reasons, the stornwater can be diverted to the ETF basins, as described in "9.2.2. Diverted Water Basins." 


\section{EXTENDED SLUDGE PROCESSING (ESP)}

\subsection{Function}

Extended Sludge Processing madifies the sludge composition to prepare the sludge for feed to DWPF Vitrification. The purpose of processing is to reduce the volume of glass that is produced (i.e. allows much higher waste loading of sludge in glass). ESP modifies the aludge composition in two ways: 1) insoluble aluminum compounds are removed from thowe sludges that contain high concentrations of insoluble aluminum, and 2) all sludge is washed to remove soluble salts.

\subsection{Description of ESP}

\section{ESP Process}

As described in Chapter 5, an insoluble sludge is formed when Separations adds sodium hydroxide to the fresh waste being sent to the Tank Farms. Extended Sludge Processing (ESP) converts insoluble aluminum compounds into soluble compounds by contacting the sludge with high concentrations of sodium hydroxide at near-boiling temperatures. After the aluminum bas been solubilized, ESP washes the soluble salts (e.g., sodium nitrate) from this sludge by washing it with water. Both of these operations reduce the quantity of glass produced when the sludge is vitrified into waste glass.

ESP operates on large batches of sludge, so the entire current Storage and Evaporation inventory will be treated in about 6 batches. Each batch will be analyzed and then will supply DWPF for a 2-6 year period. This time period may be altered by the achievable operating attainments, or it may be limited by the waste removal schedule (i.e., when the next batch of sludge will be available). While ESP processes a batch of sludge (in Tank $42 \mathrm{H}$, and either Tank $51 \mathrm{H}$ or $40 \mathrm{H}$ ), the previous batch will be fed to DWPF from the other tank (i.e., either $40 \mathrm{H}$ or $51 \mathrm{H}$ ).

\section{Extended Sludre Processing Enuipment}

Extended Sludge Processing (Figure 7-1) includes and interfaces with the following equipment:

Tank 42H - This Type IIIA tank is used for the aluminum diseolution reaction and for sludge washing. This tank is equipped with steam spargers for heating and slurry pumps for agitation.

Tanks 40H and 51H- Each of these Type IIIA tanks is used for sludge washing and for feeding washed sludge to the DWPF.

Tank 21H - This Type IV tank is used to store spent wash water from ESP. This tank is administratively part of the Storage and Evaporation process and has functions other than ESP, but it functions as part of the ESP process.

ITP Control Building - This building houses the Instrument Control Room and the Electrical Control Room for the ESP equipment (in addition to performing the same functions for ITP; see chapter 6).

ITP Cold Feeds Area - This area contains tanks, pumps, piping, and instrumentation necessary to receive, store, and add nonradionctive reagents to the ESP process (in addition to performing the same functions for ITP; see chapter 6). 
Diversion Boxes 5, 7, and 8 - These boxes are used to transfer solutions and slurries between tanks.

\subsubsection{Aluminum Dissolution}

Part of the sludge inventory contains large amounts of aluminum, which can be partially removed (dissolved) by heating the sludge in a high caustic concentration. If the aluminum were not removed, then DWPF would have to increase the ratio of frit-to-waste (to control the viscosity and liquidus of the moltea glass), increasing the number of glass canistera produced.

Aluminum dissolution is dose in Tank 42 by adding caustic (NaOH) to the sludge, to achieve a certain hydroxide-to-Aluminum ratio and a certain excess hydroxide concentration. The sludge solids are suspended by using slurry pumps for agitation, and the temperature is raised by injecting steam through sparging downeomers. Maintaining this condition for several days converts the $\mathrm{Al}_{2} \mathrm{O}_{3} \cdot(3) \mathrm{H}_{2} \mathrm{O}$ (gibbsite) to a soluble form (e.g., $\mathrm{Al}(\mathrm{OH}) 3$, or $\mathrm{AlO}_{2}$ ). After the sludge solids are allowed to settlo, the supernate containing dissolved Aluminum is then decunted from the tank.

One concern with the process is that uranium becomes more soluble under the bigh hydroxide conditions that exist during Aluminum Dissolution. Therefore, fissile isotopes of uranium (mainly U-235)

dissolved during Aluminum Dissolution could potentially cause a criticality when the decanted supernate is evaporated and subsequently redissolved. Criticality is not a concern during Aluminum Diseolution or during evaporation of the decanted supernate because the urnium will remain distributed throughout the salt. However, when the saltcake is rodissolved, somo urnaium may remin insoluble, and there is the potential that this uranium would concentrate at the bottom of the tank and form 2 critical mass. Studies are currently underway to determine if this mochanism is credible and if any controls are needed to prevent criticality.

The selection of specific sludges to undergo Aluminum Dissolution is described in section "7.3.1.

Washed Sludgo-Interface Stream 4." The disposition of decanted supermate from Aluminum

Dissolution is described in section "7.3.2. Decanted Supernate-Interface Stream 3." 


\section{Figure 7.1 Extended Sludge Processing}

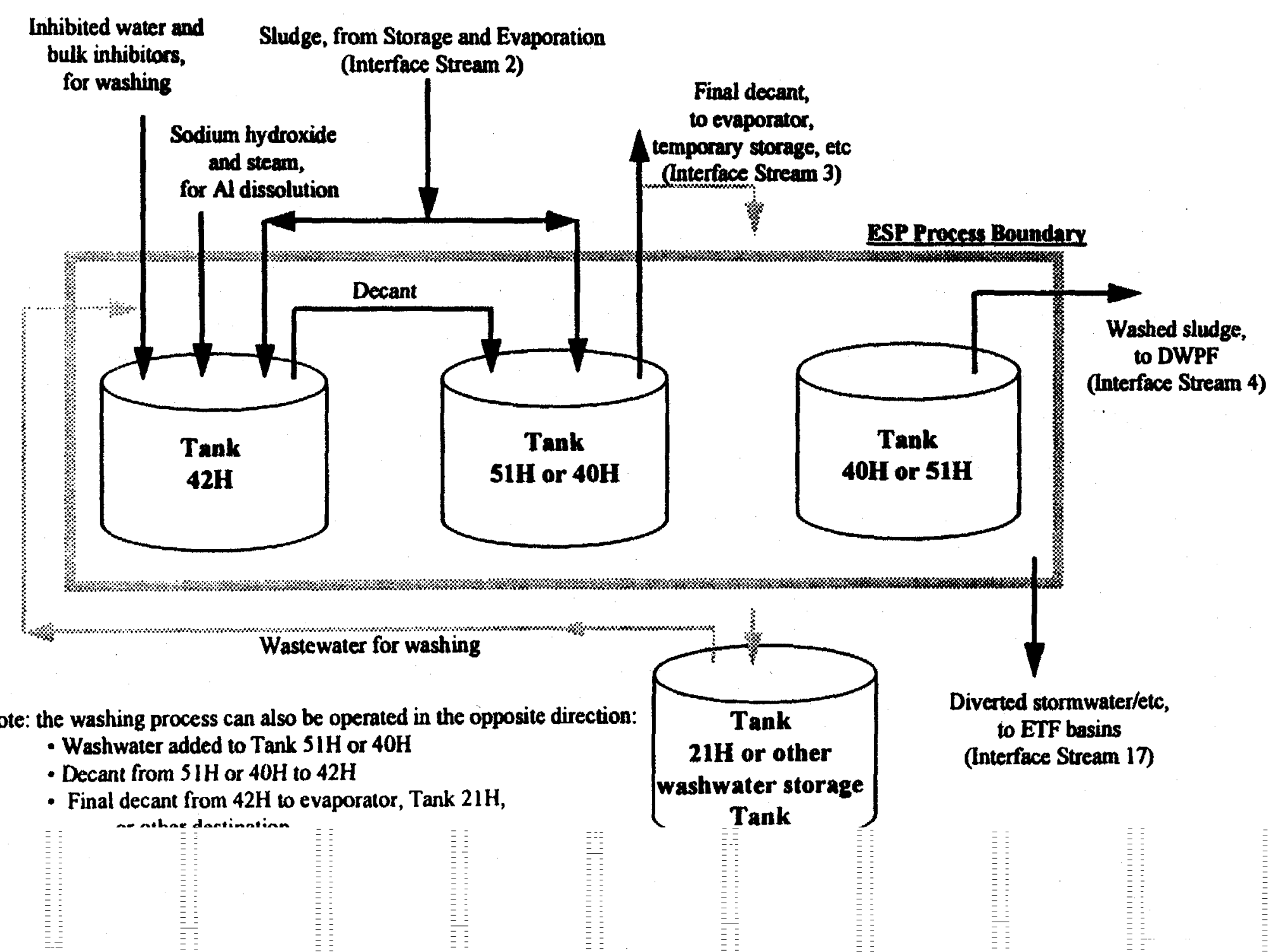




\subsubsection{Soluble Salt Washing}

Although the sludge has settled and compacted in the various waste tanks for 5 to 30 years, that settled volume still contains a large fraction of liquid. This interatitial supernate contains a large amount of dissolved salt (present as $\mathrm{NaOH}, \mathrm{NaNO}, \mathrm{NaNO}_{2}, \mathrm{NaAlO}_{2}, \mathrm{Na}_{2} \mathrm{CO}_{3}, \mathrm{Na}_{2} \mathrm{SO}_{4}$, etc). If this salt were not removed, then DWPF would have to increase the ratio of frit-to-waste (to control the rheology of the molten glass). This would greatly increase the number of glase canisters produced. Other reasons for removing the soluble salts include reducing DWPF's atmospheric NOx emissions, and to moet requirements for glass insolubles and corrosive species.

The soluble salts are removed from the interstitial supernate by repeated dilution. First, washwater (with a low salt content) is added to the tank and the sludge solids are suspended using slurry pumps for agitation. Then the sludge solids are allowed to settle and the diluted supernate is decanted from the tank. This cycle is repeated until the salt content of the interstitial supernate is sufficiently low. To control nitrate induced corrosion, inhibitor salts (i.e., $\mathrm{NaOH}$ and $\mathrm{NaNO}$ ) must be added along with the washwater. The makeup washwater may be fresh water or it can be some other waste solution with a sufficiently low selt content.

The salt washing process is expected to take plece sequentially in both processing tanks (i.o., Tank 42H, and either Tank $51 \mathrm{H}$ or $40 \mathrm{H}$ ) where the 'used' washwater decented from the first tank is then 'reused' in the second tank. This process, often called "cowashing," reduces the total volume of spent washwater produced (thus minimizing the load on the $2 \mathrm{H}$ evaporator) but it requires additional washing cycles. Many other factors impact the number of wash cycles and the total decant volume, e.g., the amount of washwater used in each cycle, the time the sludge is allowed to settle, and the amount of supernate left covering the sludge when the decanting ends. These tradeoffs also impact the total duration of the washing process and will have to be re-optimized when conditions and constraints change.

The disposition of decanted supernate from sludge washing is described in "7.3.2. Decanted Supernate-Interface Stream 3."

\subsection{Effluent Streams and Key Process Controls}

\subsubsection{Washed Sludge-Interface Stream 4}

ESP determines the concentrations of aluminum, soluble salt and insoluble solids in the sludge fed to DWPF for vitrification:

- The Aluminum content is partially determined by the dissolution process, which has a relatively high efficiency for that part of the total aluminum which is susceptible to dissolution. Other forms of aluminum are not affected by the aluminum dissolution operating conditions, as described in "7.4.1. Untreated Sludge-Interface Stream 2." Thus the overall Aluminum removal efficiency and the Aluminum content of ESP's product is partially determined by the blending provided by the waste removal schedule. The allowable aluminum content is limited by the DWPF feed design bases ${ }^{14}$ to ensure the molten glass has a satisfactory theology. If the aluminum is outside of these limits, this will increase the number of canisters at DWPF and increase the cost of processing. The DWPF limit applies to the final mixture composition after Tank $42 \mathrm{H}$ is combined with Tenk $51 \mathrm{H}$ or $40 \mathrm{H}$.

- The soluble salt content is controlled by the salt washing process. The allowable salt content is limited by the DWPF feed design bases it because of several factors. These ensure the molten glass has a satisfactory theology (i.e., $\mathrm{Na}^{+}$) and meets the limits on giass insolubles and 
corrosive species (e.8., $\mathrm{Cl}^{-}$and $\mathrm{SO}_{4}=$ ). This also ensures that DWPF meets the air emissions permit for $\mathrm{NO} x$ (i.e., $\mathrm{NO}_{2}^{-}, \mathrm{NO}_{3}^{-}, \mathrm{OH}^{-}$). The allowable salt contents can be affected by some insoluble species present in the sludge (e.g., part of the sodium).

- The insoluble solids content is controlled by the extent that the sludge is allowed to settle for the final decent operation. If the wt\% solids is too high, then the slurry's theology could be stiff enough to make it difficult to pump from Tank 51H or 40H to DWPF. As the wt $\%$ solids decreases, then DWPF requires additional time to process the same amount of solids (i.e., more boiling is required in the Slurry Receipt Adjustment Tank). Also, the water content of the sludge slurry sent to DWPF is all returned beck to the Storage and Evaporation in the DWPF recycle stream (Interface Stream 10). The slurry and transfer pumps will leak some of their bearing water into the feed tank, gradually diluting the wt\% insolubles. This dilution may require that additional supermate be decanted periodically. Each decant would require a process outage to allow several weeks for the sludge to settle, and would change the salt content of the sludge (i.e., the ratio of insoluble:soluble solids).

The DWPF Feed Design Bases" also documents the impacts of numerous other species, but those concentrations are determined by the waste removal schedule in the HLW System Plan. ${ }^{6}$ The schedule provides for limited blending, based either on process knowledge of waste origins and transfers, or on waste tank sampling. Because of the small amount of sludge in most tanks compared to ESP batch size, some blending will naturally occur.

The unwashed sludge transferred into ESP must have an appropriate composition such that the DWPF requirements ${ }^{14}$ for ESP's processed sludge will be met. Otherwise, DWPF's trim chemicals or frit composition may have to be adjusted. The HLW Material Evaluation Board and TOST are responsible for resolving the non-compliance, including the impucts or operational cost. See "8.4.1. High-Level Waste Feed Streams" for a discussion of species whose composition is important to DWPF.

\subsubsection{Decanted Supernate--Interface Stream 3}

\subsubsection{Disposition Alternatives}

Recycling the decants from ESP for beneficial use (rather then evaporating them) will require meshing the various transfer schedule requirements. Initially, tank $21 \mathrm{H}$ will be used for temporary storage. Later, other tanks could be used as more spare tank space becomes available (i.e., as the waste removal program proceeds). Options for beneficial use have been reviewed. ${ }^{2}$

The supernate decented after Aluminum dissolution can be sent to various destinations depending on the composition and various production planning needs:

- It cen be fed to the HLW evaporators, but the high hydroxide content will limit the evaporator's volume reduction factor (the Aluminum dissolution supernate will not crystallize well).

- The high hydroxide content would actually be desirable for dissolving salt to feed ITP.

- Depending on its salt and radionuclide content, the supernate can be fed directly to ITP, e.g., if Ru-106 meets the Z-area waste acceptance criteria. ${ }^{13}$

Decanted spent washwater can also be sent to various destinations, depending on the composition and various production planning needs:

- It can be fed to the HLW evaporators. 
- The initial decantw, which will contain a large amount of salts, can be used to slurry sludge for the next ESP batch.

- Depending on its salt and radionuclide conteat, the supernate can be fed directly to ITP, e.g., if Ru-106 meets the Z-area waste acceptance criteria."

- Each subsequent decant will contain a decreasing amount of salt, and later decants can be used to dissolve salt to feed ITP.

- Dilute decants can be held for reuse as makeup washwater in the initial washes of the next sludge batch.

The optimum destination for the decanted solutions will have to be determined as conditions and constraints chenge.

\subsubsection{Corrosion Inhibitor Content}

Meeting the Technical Standards ${ }^{21}$ (soon to be superseded by the ESP Process Requirements) in the ESP tanks will neturally reault in docant solutions that are inhibited for their nitrate contents. However, the receiving waste tank's inhibitor and nitrate contents may be such that inhibitors have to be added (to the receiving tank) for the mixture to comply with the Technical Stendards. ${ }^{21}$

\subsubsection{Additional Limits for Tyoe IV Tanks}

The Technical Standards, ${ }^{21}$ which limits the Cs-137 concentration of liquids added to the Type-IV tanks could restrict opportunities to bold decant solution in Tank 21H. After the initial wash cycles on a batch of sludge, the decants could be seat to a Type IV tank.

\subsubsection{Storm Water Runoff (Clean and Diverted)-Interface Stream 18}

Storm water rumoff from the ESP tanks is sent directly to a NPDES outfall after the online monitor determines that it is 'clean'. If the monitor detects contamination, or for any of several administrative/precustionary reasons, the stormwater can be diverted to the ETF besins, as described in “9.2.2. Diverted Water Basins."

\subsection{Influent Streams and Key Process Variables}

\subsubsection{Untreated Sludge-Interface Stream 2}

The DWPF Feed Derign Bases" documents the impacts of numerous species, see "8.4.1. High-Level Waste Feed Streams," several of which are controlled by ESP. The other concentrations are determined by the wasto removal schedule," which provides a blended sludge based on process knowledge of waste origins, transfers, and on limited tank sampling. Since the original blending plan was developed, the waste removal project budget has shifted several tanks to later batches. The new expected batch compositions have been estimated. The unwashed sludge transferred into ESP will either have an appropriate composition such that the DWPF requirements ${ }^{14}$ for ESP's processed sludge will be met, or the HLW Material Evaluntion Board will resolve the matter (See section 4.2. 1. HLW Material Evaluation Board). 
The Tank Farm sludge inveatory is categorized based on the source of the sludge, which generally determines the composition (e.g., PUREX -vg- HM, and high heat -vs- low heat). In particular, high heat HM sludge contains large amounts of alumimum. The waste removal schedule ${ }^{6}$ selects certain tanks to undergo the Aluminum discolution process. Some aluminum is present as $\mathrm{Al}_{2} \mathrm{O}_{3} \cdot(1) \mathrm{H}_{2} \mathrm{O}$ (beohmite) and as aluminum-silice compounds, which are not soluble at ESP's dissolution temperature.

The radionuclide content of the sludge is limited by the DWPF Feed Design Basis and also by the timeto-LFL in ESP tanks (see "7.4.2. Washwater").

The maximum amount of sludge in each ESP process batch is limited by the slurry pump's capability to suspend the solids and by the maximum washwnter volume allowable.

\subsubsection{Washwater}

Fresh water can be used as makeup wasbwater after adding a small amount of hydroxide and nitrite inhibitors to comply with the Tank Farm Technical Standards, ${ }^{21}$ which will be superseded by the ESP Process Requirements. Alternatively, various dilute wastewater solutions could be used as washwater when their salt content is sufficiently low to effectively dilute the interstitial supernate in the sludge. For example, the DWPF recycle stream could be used as washwater, or some ESP decants could be re-used in the next ESP batch, see "7.3.2.1. Disposition Alternatives." Using dilute wastewater could reduce the total amount of feed that the evaporators must eventually process, although requiring more washing cycles in ESP.

The total volume of washwater used for each ESP batch is minimized by performing more wash cycles, each one using a small volume of water. Alternatively, the total processing time can be redriced by doing fewer washes, each one using a larger volume of water (and increasing the total washwater volume). The maximum volume of washwater is limited by the ESP OSR ${ }^{12}$ requirement for a minimum time-to-LFL (i.e., upon loss of ventilation), because higher volumes of washwater decrease the available vapor space, which decreases the time to LFL.

\subsubsection{Raw Materials}

Caustic and sodium nitrite are used as corrosion inhibitors, both for bulk additions to the ESP processing tanks and for minor additions to the makeup washwater stream.

Caustic and steam are used in the aluminum dissolution phase of ESP. 


\section{DEFENSE WASTE PROCESSING FACILITY (DWPF) Includes Late Wagh Facility (LWF)}

\subsection{Function}

The primary function of the DWPF is to process high level wastes (in the form of washed precipitate and washed sludge) into a borosilicate glass, canistered waste form which meets the requiremeats of the Federal Repository.

The DWPF will also produce recycle streams (spent wash from the LWF and DWPF recycie) which meet the Storage and Evaporation's acceptance criteria, and produce an organic waste stream which meets the acceptence requirements of the Consolidated Incinerator Fecility (CIF).

\subsection{Description}

For the purposes of this document, the DWPF process can be divided into five functional areas (seo Figure 8-1):

1. Late Wash Facility (LWF), which washes water soluble components from the tetraphenylborate (TPB) precipitate slurry which has been stored in Tank 49H;

2. Salt Process Cell (SPC), which hydrolyzes the TPB precipitute slurry;

3. Chemical Proceses Cell, which prepares melter feed by chemically treating the washed sludge and combining it with bydrolyzed precipitate and glass frit;

4. Melt Cell, which vitrifies the feed prepared in the CPC, pours the molten glese into stainless steel canisters, and scrubs the melter offgas; and

5. Canister Closure and Decontamination, which seals the cenister and cleans its exterior for transfer to the Glass Waste Storage Building (GWSB) and eventually to a Federal Repository.

\subsubsection{Late Wash Facility}

In ITP, the procipinte is wubed to reduce levels of soluble species (preveating excessive glass production) and is inhibited with $\mathrm{NaNO}_{2}$ to prevent corrosion. However, the conceatration of $\mathrm{NaNO}_{2}$ required to inhibit corrovion is too high for the precipitate hydrolysis process. Also, while the precipitato is atored in Tank 49H, water soluble orgenic species are produced by radiolysis of the TPB. These organic species also impact precipitate hydrolysis operability by reducing the copper catslyst activity. 
High-Level Waste System Process Interface Description

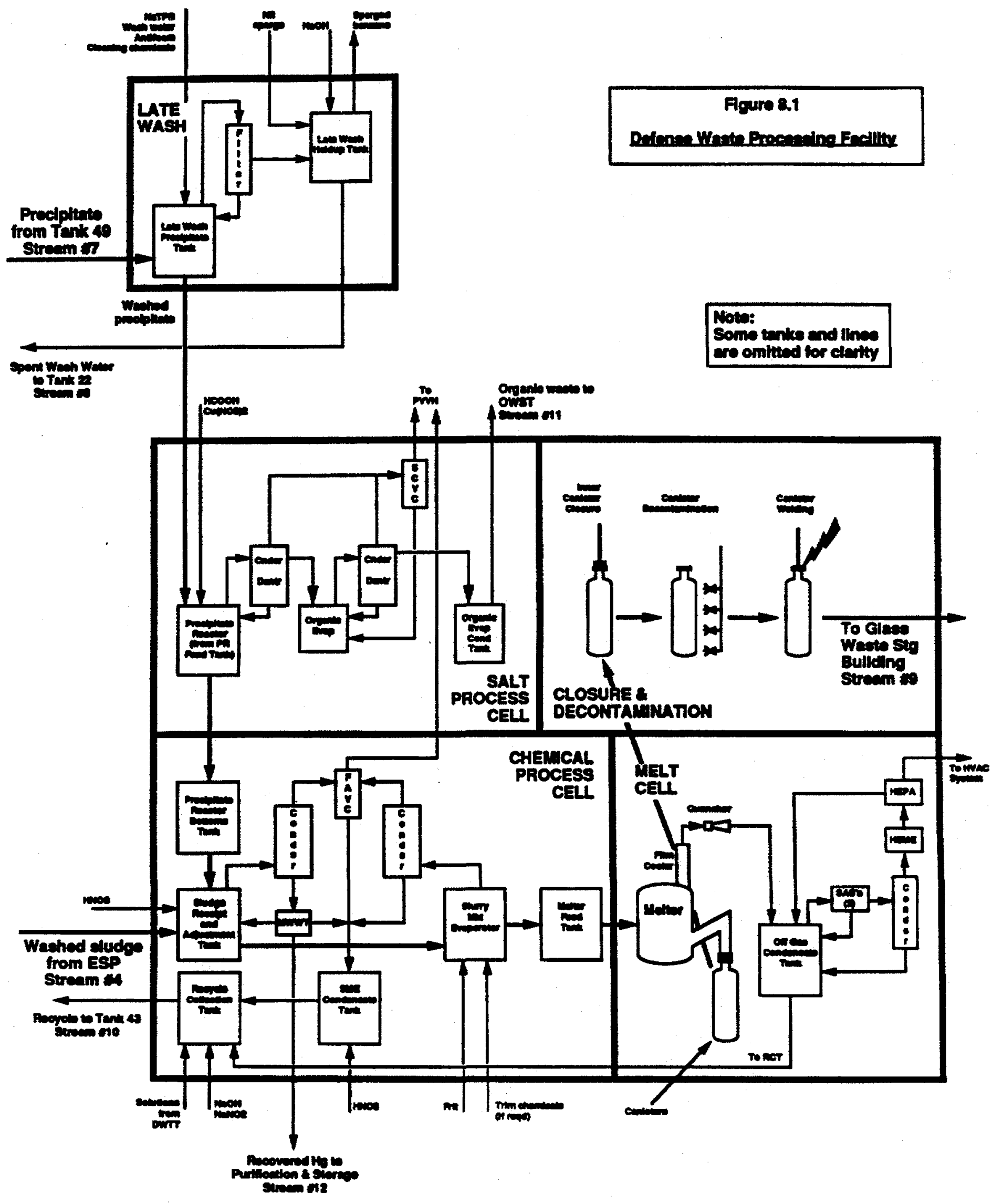


To avoid problems in precipitate hydrolysis, the LWF washes the precipitate to recuce the concentration of $\mathrm{NaNO}_{2}$ and water soluble orgenic radiolysis products.

The precipitate slurry (Interface Stream 7) is pumped into the Lato Wash Precipitate Tank (LWPT) where soluble Cs and $\mathrm{K}$ (from radiolysis of Cs, KTPB) are reprecipitated with NaTPB. The slurry is then concentrated to the desired percent solids using a sintered metal crossflow filter. It is then washed with a dilute NaTPB solution (to prevent dissolution of CsTPB) until the nitrite and soluble organics concentrations are reduced to levels compatible with precipitate hydrolysis. ${ }^{24}$ The washed slurry may be further concentrated prior to transfer to the DWPF.

Filtrate from the washing and concentration steps flows to the Late Wash Holdup Tank from which it will be transferred to Tank 22H (Interface Stream 8). To meet ITP requirements for benzene, pH and inhibitors, the filtrate is sparged with $\mathrm{N}_{2}$ to remove the diseolved benzene and $\mathrm{N}$ OHF is added. LWF vessels containing benzene and hydrogen due to rediolysis, are purged with nitrogen to maintain them below the minimum oxygen for combustion (MOC).

Additional chemicals will be used in the LWF. The filter will require periodic cleaning with oxalic acid and caustic. Foaming in the Late Wash Precipitate and the Late Wash Hold Tanks will be controlled by the addition of an antifonm, Surfynolo 420.

\subsubsection{Salt Process Cell (SPC)}

\subsubsection{SPC Chemistry}

The washed and concentrated Cs, KTPB precipitate/ $\mathrm{NaTi}_{2} \mathrm{O}_{5} \mathrm{H}$ slurry is acid hydrolyzed and steam stripped in the Salt Process Cell. The purpose is to remove the aromatic organics from the Cs-containing aqueous stream which is ultimately fed to the melter because high concentrations of organic interfere with melter operation. The desired reaction is

$$
\begin{aligned}
& \mathrm{Cu}^{+2} \\
& \mathrm{Cs}, \mathrm{KB}\left(\mathrm{C}_{6} \mathrm{H}_{5}\right)_{4}+\mathrm{HCOOH}+3 \mathrm{H}_{2} \mathrm{O} \Rightarrow \mathrm{Cs}, \mathrm{KCOOH}+4 \mathrm{C}_{6} \mathrm{H}_{6}+\mathrm{B}(\mathrm{OH})_{3}
\end{aligned}
$$

resulting in soluble $\mathrm{Cs}_{s}$ formate and benzene. However, since the reactions involve free radicals and ionic species such as nitrite, byproducts are formed such as phenol, biphenyl, aniline, diphenylamine, terphenyl, etc. Because of the preaence of the volatile, flammable benzene, all the process vessels in the SPC are purged with $\mathrm{CO}_{2}$ (or $\mathrm{N}_{2}$ ) to meintain the $\mathrm{O}_{2}$ concentration below the Minimum Oxidant for Combustion.

Another reaction of interes is the reduction of diphenyl mencury (precipitated by TPB during In-Tank Precipitation) to elemental mercury. The reaction proceeds by formic acid cleavage to the phenyl mercuric ion followed by reduction to elemental mercury. This reaction must occur sufficiently to meet the CIF limit on mercury since the biphenyl mercury easily steam strips to the recovered organic phase.

\subsubsection{SPC Descriotion}

The washed slumy is transferred to the Precipitate Reactor Feed Tank (PRFT) in the Salt Process Cell for feeding to the Precipitate Reactor (PR). Prior to feeding, formic acid and copper catalyst (either copper formate or copper nitrate) are added to the reactor heel. Then the slurry is fed and the reactor is heated to boiling. Benzene is evolved as it is formed (the bydrolysis reactions begin as soon as the feed enters the PR) and the stepwise reactions continue through the aqueous boiling step. Other aromatic organics 
are steam stripped during aqueous boiling and are condensed with the benzene and water. The aqueous/organic condensate is decanted with the aqueous recycling to the PR and the organics to the Organic Evaporator (OE).

A second evaporation step is performed to assure the recovered organic waste is sufficiently decontaminated for transfer outside of the DWPF canyon (Interface Stream 11) to the Organic Waste Storage Tank (OWST) and from there to the CIF. Water is added to the OE and the boiling, steam stripping, condensing, decanting cycle is repeated. The twice-distilled organic is collected in the OE Condensate Tank (OECT) and analyzed for activity and for mercury.

After steam stripping and cooling in the PR, the remaining aqueous phase is known as PHA (precipitate hydrolysis aqueous). The PHA is then transferred to the Precipitate Reactor Bottoms Tank (PRBT) where it held until fed to the Sludge Receipt and Adjustmeat Tank (SRAT). The NaTi $\mathrm{O}_{5} \mathrm{H}$, and the radionuclides which were adsorted on the titanate, remain with the aqueous phase and are ultimately fed to the melter.

All vessels in the SPC are collectively maintained under a slight vacuum and vented through the chilled Salt Cell Vent Condenser (SCVC) into the Process Vesell Veat Header (PVVH). The primary purpose of the SCVC is to limit benzene emissions and to prevent a flammable benzene mixture in the PVVH. The PVVH exhausts to the atmosphere through the sand filter after combining with the Zone 1 ventilation system.

\subsubsection{Chemical Process Cell (CPC)}

\subsubsection{CPC Description}

The purposes of the Chemical Process Cell (CPC) are to complete preparation of the melter feed and to collect and adjust the aqueous recycle stream. In fact, the CPC is also known as Melter Feed Preparation.

Sludge (Interface Stream 4) which has been prepared in Extended Sludge Processing (aluminum dissolved and washed) is transferred into the Sludge Receipt and Adjustment Tank (SRAT). Sufficient nitric acid is added to react components such as nitrite and carbonate, to obtain an acidic pH (required for control of slurry rheology), and to provide the required reduction-oxidation balance between formate and nitrate. PHA is then added to the SRAT and excess water is boiled off, condensed, and collected in the SME Condensate Tank (SMECT); if an antifoum is needed in the SRAT or SME, Dow Corning 544 will be used. Excess formic acid in the PHA also contributes to desired $\mathrm{pH}$ as well as reducing $\mathrm{HgO}$ to elemental mercury and $\mathrm{Mn}^{+4}$ to $\mathrm{Mn}^{+2}$ (reduces foaming in the melter). Elemental mercury is steam stripped during the concentration step and is collected in the Mercury Water Wash Tenk (MWWT). The mercury is periodically pumped to a shielded cell where it is acid washed, water washed, and vacuum distilled in preparation for eventual disposition (Interface Stream 12).

The acidified and concentrated sludge and PHA are then transferred to the Slurry Mix Evaporator (SME) where glass frit slurry is added and excess water is again boiled off, condensed, and collected in the SMECT. If any composition adjustments are required, the trim chemicals are added in the SME prior to transferring the combined sludge, PHA, frit slurry to the Melter Feed Tank (MFT). The melter is fed continually from the MFT.

All the vessels in the CPC are maintained at a slight vacuum and collectively vented through the chilled Formic Acid Vent Condenser (FAVC) into the PVVH, and ultimately to the atmosphere. The primary purpose of the FAVC is to limit mercury emissions. In addition to air leakage from the vacuum, air is added to CPC vessels to dilute potentially flammable concentrations of hydrogen (produced both by 
¿

High-Lovel Wate System Process Interface Description

noble metal catalyzed decomposition of formic acid and by radiolysis), and benzene from the PHA. Also, the CPC vessel vent system incorporates three ammonia scrubbers (directly downstream of the SRAT and SME condensers and on the RCT vent) to mitigate deposition of ammonia nitrate in ventilation system piping. (Ammonia is present in the precipitate slurry as $\mathrm{NH}_{4}$ TPB and is generated by chemical reaction in the SRAT; $\mathrm{NO}_{\mathrm{x}}$ is generated from nitrite and nitrate reactions in the SRAT.) SMECT condensate is used for ammonia scrubbing and nitric scid will be added to the SMECT as needed to maintain the proper $\mathrm{pH}$ for scrubbing.

The RCT collects condensate from the SRAT and the SME and from the melter Off Gas Condensate Tank (OGCT) for recycle to Storage and Evaporation (Interface Stream 10). Prior to transfer, NaOH and $\mathrm{NaNO}_{2}$ are added to meet Storage and Evaporation inhibitor requirements. The RCT also periodically processes solutions from the Decontaminated Waste Treatment Tank (DWTT). These are neutralized solutions from equipment decontamination and solutions/slurries from dissolution of HEMEs (High Efficiency Mist Eliminator) and HEPAs (High Efficiency Particulate Air-filter).

\subsubsection{Product Composition Control}

The melter feed composition, and thus the glass composition and its properties, are controlled by the Glass Product Control Program (GPCP). The GPCP uses 1) sample analyses and tank inventories from three process locations (the SRAT, the PRBT, and the SME) 2) frit composition and frit slurry makeup volumes, and 3) statistical methodology to control the glass product.

A computer program, the Process Composition Control System (PCCS), has been developed to perform these functions. Taking into account the uncertainties in property correlations, physical measurements, sampling, and analytical results, the PCCS determines the appropriate mix of sludge, PHA, and frit to meet six objective functions: 1) glass durability, 2) melt viscosity, 3) melt liquidus (the temperature at which the first portion of the glass starts to solidify), 4) minimum frit (that is, maximum waste loading), 5) limits for glass insolubles, and 6) glass predictability (meaning the degree to which the glass composition is within the range of compositions that has been studied. A high predictability means the glass composition is well within the studied range, and the glass's properties can be predicted with confidence).

If necessery, trim chemicals (NaOH, $\mathrm{KNO}_{3}, \mathrm{H}_{3} \mathrm{BO}_{3}$ (boric acid), and/or frit) can be added to the SME. A confirming sample is taken from the MFT and occasional glass samples will be taken from the melter pour stream to confirm glass durability.

\subsubsection{Melt Cell}

The combined sludge, PHA, and frit are fed continuously to the melter where the mixture is vitrified and poured into stainlese steel canisters. The melter is heated primarily by joule heating (resistance beating) from DC current passing through the molten glass. The secondary source is radiant heating from resistance heating of metal rods in the melter plenum.

The slurry from the MFT is fed onto the molten glass pool in the melter. Water from the slurry feed is vaporized and volatile organics are burned in the plenum space or at the cold cap. (The cold cap is an "island" of feed material floating on the molten glass where much of the vaporizing and burning takes place. The cold cap disappears when the melter is not being fed.) Also several combustion and oxidation/reduction reactions cocur generating off-gases of $\mathrm{CO}, \mathrm{CO}_{2}$, and $\mathrm{NO}_{\mathrm{x}}$. The sources of oxygen are air, nitrate, and reduction of $\mathrm{Fe}_{2} \mathrm{O}_{3}$ to $\mathrm{FeO}$. The primary reducing agent is the formate ion.

The melter offges, which includes gases ( $\mathrm{CO}, \mathrm{CO}_{2}$, hydrogen and $\left.\mathrm{NO}_{x}\right)$, entrained glass, vaporized salts (sulfates, chlorides, borates), semi-volatile forms of $\mathrm{Cs}$ and $\mathrm{Ru}$, and various forms of mercury, flows into 
-

High-Level Wate System Proceen Interfice Deccription

tho Melter Off Gas (MOG) gystem. The MOG system maintnins the melter under a slight vecuun and sufficiently eleans the offiga stream for eventual venting to the atmosphere. The MOG system consists of

1. A film cooler and quencher, which use steam and water, respectively, to cool, condense, and partially scrub the offgas while minimizing plugging from salts and glass,

2. An Off Gas Condensate Tank which collects the condensate and removes heat,

3. Steam Atomized Scrubbers (SASs) which use steam and offgas condensate to serub semi-volatile Cs and Ru from the non-condensable gases,

4. A chilled OGCT condenser which primerily limits elemental mercury emissions, and

5. A HEME and a HEPA to remove serosols and particulates.

The melter feed composition is controlled such that a borosilicate glass with the required durability (leach rate) is produced. The radioactive components present in High Level Waste are immobilized either by becoming part of the glass matrix (for example, $U$ and $\mathrm{Pu}$ ) or by being encapsulated within the glass matrix (for example, $\mathrm{Cs}$ and Sr). The molten glass is vacuum poured into a stainlese steel canister where it is allowed to cool and solidify.

\subsubsection{Canister Closure and Decontamination}

After filling, the canister must be cleaned and sealed prior to transferring to the Glase Waste Storage Building (GWSB) where the canisters will be temporarily stored until the Federal Repository is ready (Interface Stream 9).

The first step is the insertion of a temporary plug called the Inner Canister Closure. The purpose of the Inner Canister Closure is to exclude water during the subsequent cleaning step.

During filling, the heat from the molten glass causes formation of an oxide coating on the canister. This coating is contaminated with radioactivity which could easily spread unleas the canister is cleaned. Decontamination is accomplished in either of two Canister Decontamination Chambers (CDCs) by blasting the canister with a dilute slurry of glass frit followed by rinsing with clean water. Smear testing is performed to assure the canisters are sufficiently clean to move on to the weld test cell.

The final closure is made by forcing the Inner Canister Closure and the canister nozzle into the canister neck and then welding the final weld plug using an upset resistance welding process. The canister is smear tested once more before transfer to the GWSB.

\subsubsection{Process Air Emissions}

The DWPF will be operating under an air permit from South Carolina SCDHEC. ${ }^{25}$ The permit limits emissions of mercury, benzene, $\mathrm{NO}_{\mathrm{x}}$, and $\mathrm{CO}$, of which mercury, benzene and $\mathrm{NO}_{\mathrm{x}}$ are monitored. The sources for these compounds are the LWF (benzene), the SCVC (benzene and mercury), the FAVC (mercury, $\mathrm{NO}_{\mathrm{x}}$, and benzene), the OGCTC (mercury, $\mathrm{NO}_{\mathrm{x}}$, and $\mathrm{CO}$ ), and the OWST (benzene). In addition, radionuclide emissions from the DWPF ventilation system are permitted by the EPA. 
Emissions from the various sources are determined and/or controlled as follows:

- Benzene emissions from the LWF are primarily determined by the dissolved benzene in the precipitate as received from Tank $49 \mathrm{H}$,

- SCVC benzene and mercury emissious are a function of the air inicaicage, the inert purge requirements and the operating temperature of the SCVC.

- $\mathrm{NO}_{x}$ emissions (both from the FAVC and the OGCTC) are determined by the nitrite and nitrate in the feeds (precipitate and sludge) and by the amount of nitric acid added in the DWPF (which depends on the hydroxide, mercury, and manganese in the sludge feed).

- The benzene from the FAVC is determined by the amount of benzene and benzene precursors in the PHA.

- Mercury from both the FAVC and OGCTC is determined by the non-condensable flow and the FAVC operating temperature.

- Carbon monoxide from the OGCTC is a function of the carbon fed to the melter and the completeness of combustion.

- The OWST benzene emissions are limited by the floating roof in the tank.

DWPF administrative controls require monitoring and projecting DWPF emissions on a routine frequency.

\subsection{Effluent Streams and Key Process Controls}

\subsubsection{The Canistered Waste Form--Interface Stream 9}

The canistered waste form (the glass + the canister) is the principle product of the DWPF. The DOE has specified the requirements for the canistered waste form in the Waste Acceptance Product Specifications (WAPS). ${ }^{26}$ The specifications apply to the canister itself, to the integrity/cleanliness of the canister, and to the glass. The DWPF Waste Form Compliance Plen (WCP) ${ }^{16}$ details the strategies for meeting the specifications and the multi-volume Waste Form Qualification Report (WQR) ${ }^{27}$ contains the objective evidence supporting our ability to meet the WCP. The Glass Product Control Program (GPCP), which is a part of the WQR, details the strategies used to ensure that glass property requirements are met through control of the melter foed composition. Items and activities important to the DWPF's ability to comply with the WAPS are identified and maintained in the DWPF Waste Acceptance Reference Manul. ${ }^{2}$ Modification to these items and activities must go through DWPF change control and be reviewed for impact on DWPF's ability to meet the WAPS.

Changes to the WAPS affecting the canister itself or the canister integrity/cleanliness are unlikely to have any impacts on the rest of the HLW System. However, any changes dealing with the borosilicate glass (for example, product durability, chemical composition, or radionuclide inventory) could potentially affect feed requirements from ITP and ESP.

\subsubsection{Canister Requirements}

Requirements for the canister itself are controlled during canister fabrication and verified by inspections. The requirements specify materials of construction (austenitic stainless steel), labeling (number of labels, 
font type and size, required information, location, etc.), diameter, length, perpendicularity, and aeck and flange conceatricity.

\subsubsection{Canister Integrity/Cleanliness}

Several of the compliance strategies for the WAPS requirements deal with the integrity and cleanliness, both inside and out, of the canister. These requirements are Inner Canister Closure leak-tightness (to prevent water intrusion during canister decontamination), final plug weld parameters (force, current, and time to assure a leak-tight seal), exclusion of foreign materials (to prevent potentially incompatible materials from entering the canister), smearable beta/gamma (to prevent spread of contamination), and control of frit blasting parameters (to preveat breaching of the canister).

\subsubsection{The Borosilicate Glass}

Finally, there are WAPS requirements that apply to the glass itself and are a function of the process. These requirements are glass durability (leachability), minimum canister fill limits, and required reporting of estimated radionuclide inventory and heat generation rates based on composition.

\subsubsection{DWPF Aqueous Recycle Streams}

There are two aqueous recycle streams from the DWPF $L W F$ to the Storage and Evaporation process. First, spent wash water from the LWF flows to Tenk 22H, is used in the ITP process, and eventually goes to Saltstone (Z Area) as part of the decontaminated salt solution. The second is DWPF recycle which flows to Tank $43 \mathrm{H}$ and is concentrated in the $2 \mathrm{H}$ Evaporator.

\subsubsection{LWF Spent Wash Water-Interface Stream 8}

The spent wash water (filtrate) from the LWF will contain soluble salts ( $\mathrm{NaNO}_{2}, \mathrm{NaNO}_{3}, \mathrm{NaOH}$, ete), soluble Cs, soluble and sparingly soluble organics (for example, phenol and benzene) from the precipitate slurry as well as NaTPB, oxalic acid, and NaOH which are added in the LWF. The Tank Farm OSRs specify limits on Cs-137, benzeas, and inhibitors. The Tank Farm Waste Acceptance Criteria specifies the limits on Cs-137, benzene, NaOH, and corrosion inhibitors. The controls for meeting limits on Cs137 , benzene, $\mathrm{NaOH}$, and $\mathrm{pH}$ will be implemented according to the required complience plan.

\subsubsection{DWPF Recycle-Interfuce Stream 10}

The aqueous recycle from the DWPF is normally comprised of condensates from the Chemical Process Cell (from the SMECT) and from the Melt Cell (from the OGCT). Occasionally, there will be neutralized acid from equipmeat decontamination and caustic/fiberglass solutions/slurries from dissolution of HEMEs and HEPAs.

There are small quantitiea of entrained sludge, soluble and sparingly soluble organics (including nitrated aromatics), $\mathrm{HNO}_{3}, \mathrm{NH}_{4} \mathrm{NO}_{3}$, mercury compounds, and antifoum in the SMECT condensate. The OGCT condensate contains small amounts of glass particles, dissolved Cesium, nitric acid, and mercury compounds. In addition, DWPF analytical chemicals will be disposed of via the RCT and will, therefore, be present in small concentrations. The High Level Liquid Waste WAC'specifies the following items which apply to the DWPF recycle: compositionel characterization; $\mathrm{pH}$; inhibitor (hydroxide and nitrite); limits on nitrates, halides, ammonium, organics, sulfates, and silver; and characteristically hazardous wastes allowed (mercury and benzene). These requirements are implemented in the DWPF by administrative controls as specified in the DWPF Recycle Waste Compliance Plan. ${ }^{-9}$ 


\subsubsection{Recovered Organic--Interface Stream 11}

The vast majority of the TPB precipitate aromatic content is recovered in the SPC as organic waste, primarily benzene with numerous other organics including phenol, biphenyl, aniline, diphenylamine, and terphenyls. The recovered organic must meet radioactivity limits for transfer to an outside storage facility (the Organic Waste Storage Tank - OWST) and also the Consolidated Incinerator Facility's mercury limits. Administrative controls implement these requirements in the DWPF.

\subsubsection{Recovered Mercury-Interface Stream 12}

After sufficient washing and decontamination, the recovered mencury is transferred as a Low-Level Mixed Waste to Solid Waste for interim storage until eventual disposal, which is to be determined. Administrative controls in the DWPF will be used to ensure the requirements for interim storage and eventual disposal are met.

\subsection{Influent Streams and Key Process Variables}

There are two main types of "influents" into the DWPF: the high level waste feed streams and raw materials. These influents, along with bow the process is operated, determine the composition of the effluent streams.

\subsubsection{High-Level Waste Feed Streams}

The composition of the precipitate and sludge slurries have impacts on both process operations and on the effluent streams. As documented in the DWPF Feed Design Bases, ${ }^{14}$ the impacts are on NO $\mathrm{N}_{\mathrm{x}}$ emissions, canister heat generation, DWPF shielding, SAR bases, giass insolubles, process corrosion, melt viscosity and liquidus, glass durability, and process operability/attainment. These impacts are discussed individually below.

It is widely recognized that it may be necessary at times to feed material to the DWPF which is outside the DWPF Feed Design Bases and which may have significant impact in the DWPF such as operability, attainment, and waste loading in the glass. The HLW Material Evaluation Board, ${ }^{30}$ composed of HLW, DWPF, and SRTC personnel, will guide and oversee review of projected feed compositions, evaluation of impacts and alternatives, and selection of altematives.

\subsubsection{Precipitate Feed to the LWF-Interface Stream 7}

Key variables in the precipitate foed to the LWF are total and soluble Cesium concentration, solids and nitrite concentrations, dissolved benzene, and batch-to-batch homogeneity. The total Cesium concentration affects shielding requirements, and the soluble Cesium, determines the quantity of sodium tetraphenylborate required for precipitation. Solids and nitrite concentrations impact LWF attainment since batch operation can, if necessary, be modified to compensate for low solids and/or high nitrite. The dissolved benzene affects both the flammability control requirements and the benzene emissions. Batch-to-batch non-homogeneity has high impact on cycle times since considerably more pre-processing analyses are required.

\subsubsection{Sludge Feed--Interface Stream 4}

Similar to precipitate feed, dilute sludge primarily impacts DWPF attainment since batch operation would have to be altered to compensate; an additional feed and concentration step might be required. Also, 
batch-to-batch inhomogeneity would affect attrinment (more analyses) and may influeace hydrogen generation rates (variation in noble metals content).

\subsubsection{Requirements for Hirh-Level Waste Foed Streams}

\section{NO Emissions}

Nitrates and nitrites, primarily from the sludge, result in $\mathrm{NO}_{\mathrm{x}}$ emissions during SRAT processing and from the melter. Hydroxides and carbonates in the sludge affect $\mathrm{NO}_{x}$ emissions by requiring addition of nitric acid in the SRAT. Essentially all these anions are water soluble and are directly controlled by the amount of washing performed in ESP, ITP, and LWF.

\section{Canister Heat Generntion}

Radioactive decay of the radionuclides in the glass will result in heating of the glass, the canisters, and the storage facility. The primary concern is the GWSB design heat handling capacity and the potential deleterious effects of heat on the concrete strength. Canister beat generation rates are evaluated based the following radionuclides.

Precipitate: $\quad{ }^{137} \mathrm{Cs}$

Sludge: $\quad{ }^{90} \mathrm{Sr},{ }^{106} \mathrm{Ru},{ }^{137} \mathrm{Cs},{ }^{144} \mathrm{Ce},{ }^{238} \mathrm{Pu},{ }^{244} \mathrm{Cm}$

The estimated heating rates must not exceed the GWSB design basis.

\section{DWPF Shieldine Design}

The shielding for the DWPF was designed based on 5 year out-of-reactor blended sludge and 15 year out-of-reactor saltcake. If the feed stream contain any of the following radionuclides in concentrations which exceed the shielding design basis, then an evaluation of impact on shielding and personnel exposure must be performed:

Precipitate: $\quad{ }^{137} \mathrm{Cs},{ }^{238} \mathrm{Pu},{ }^{244} \mathrm{Cm}$

Studge: $\quad{ }^{60} \mathrm{Co},{ }^{106} \mathrm{Ru},{ }^{144} \mathrm{Ce},{ }^{154} \mathrm{Eu},{ }^{238} \mathrm{Pu},{ }^{244} \mathrm{Cm}$

\section{Consistency with the SAR}

The Safety Analysis Report evaluates the consequences of certain sccident scenarios besed on estimated precipitate and sludge feed compositions. Concentrations of the following radionuclides must be compared to the quantitie used in the SAR:

Precipitate: $\quad{ }^{134} \mathrm{Cs},{ }^{137} \mathrm{Cs}$

Sludge: $\quad{ }^{106} \mathrm{Ru},{ }^{144} \mathrm{Ce},{ }^{147} \mathrm{Pm}$

Both: $\quad{ }^{90} \mathrm{Sr},{ }^{235} \mathrm{U}$ (enrichment), ${ }^{238} \mathrm{Pu},{ }^{239} \mathrm{Pu},{ }^{240} \mathrm{Pu},{ }^{241} \mathrm{Pu},{ }^{241} \mathrm{Am},{ }^{242 m} \mathrm{Am},{ }^{244} \mathrm{Cm},{ }^{245} \mathrm{Cm}$

A Unreviewed Safety Question Determination is required if any of these exceed previously evaluated levels. 


\section{Glnse Insolublea}

There are a number of species which have limited solubility in the glass. If any one of these exceeds the solubility limits, secondary glass phases may be formed in the melter thus adversely affecting melter operations and life. The glass insoluble species of concern are $\mathrm{Ti}$ (primarily added as $\mathrm{NaTi}_{2} \mathrm{O}_{5} \mathrm{H}$ in ITP, $\mathrm{SO}_{4}=, \mathrm{Cr}, \mathrm{P}, \mathrm{F}, \mathrm{Cl}^{-}$, and $\mathrm{Cu}$.

\section{Corrosive Species}

Extensive corrosion evaluations have been performed on HLW Materials of construction. Mercury, sulfates, chloride, and fluoride have been evaluated at maximum anticipated levels. However, if any these concentrations are expected to be exceeded, then further corrosion testing will be required.

\section{Iron and Aluminum in the Treated Sludge}

-The DWPF was designed to produce glass with certain properties (melt viscosity, liquidus, and glass durability). These properties are determined by the composition of the melter feed. The primary components which affect these properties are iron, aluminum, alkali, and frit. The DWPF frit has been formulated based on projected compositions of treated sludge (aluminum-dissolved and washed).

Iron and aluminum in the sludge affect the melt viscosity and liquidus temperature. Excessive amounts of either would either lead to reduced waste loading in the glass (which reduces DWPF's capacity to process waste and may result in increased production of canisters) or may require reformulation of the frit.

\section{Alkali in Precipitate and Sludge}

Excessive alkali (Na and $\mathrm{K}$ ) in the glass affect melt viscosity and glass product durability. The impact is similar to excessive Iron and Aluminum in that DWPF capacity to process waste would be reduced (possibly requiring production of extra canisters). While the quantity of $\mathrm{K}$ in the precipitate cannot be controlled, the amounts of $\mathrm{Na}$ in the sludge and precipitate are controllable by washing in ESP and ITP/LWF, respectively.

(NOTE: Frit reformulation for high incoming alkali is not a realistic possibility since the DWPF frit already has essentially all the alkali removed that can be and still have a processable frit.)

\section{Miscelleneons}

Other materials for which there are no current design bases/limits but which can affect DWPF operability and glass production are zeolite, silica, and carbon.

\subsubsection{Raw Materials}

There are numerous chemicals which are added either as process chemicals or as cleaning chemicals. The requirements for these raw materials are controlled by the DWPF Essential Materials Specifications. Presented below are the DWPF raw materials:

$\underline{\text { LWF }}$

NaTPB Sodium tetraphenylborate for reprecipitation

$\mathrm{NaOH}$ Caustic for filter cleaning and $\mathrm{pH}$ adjustment of the spent wash recycle

$\mathrm{H}_{2} \mathrm{C}_{2} \mathrm{O}_{4} \quad$ Oxalic acid for filter cleaning

Surfynolo $420 \quad$ Prevents foaming of both precipitate and filtrate 
SPC

$\mathrm{HCOOH}$

$\mathrm{Cu}\left(\mathrm{NO}_{3}\right)_{2}$

Surfynol@ 104

CPC

$\mathrm{HNO}_{3}$

Frit

NaOH

$\mathrm{KNO}_{3}$

$\mathrm{H}_{3} \mathrm{BO}_{3}$

Dow-Corning 544

$\mathrm{NaOH}$

$\mathrm{NaNO}_{2}$
Formic acid for scid hydrolysis, neutralization, diphenyl mercury reaction, and excess scid to provide reducing agent in the SRAT

Cupric nitrate, $\mathrm{Cu}^{+2}$ is the hydrolysis catalyst; cupric formate can also be used

May be added to simulated precipitate during cold chemical runs to control forming in the LPPP and/or the PRFT

Nitric acid for neutralization and other reactions such as nitrite and carbonate; also for redox balance of formate

Borosilicate glase frit; can be used as a trim chemical, if needed

Caustic as a trim chemical, if needed

Potassium nitrate as a trim chemical, if needed

Boric acid as a trim chemical, if needed

For sludge fouming

Corrosion inhibitor added to the DWPF Recycle Stream

Corrosion inhibitor added to the DWPF Recycle Stream

Cleaning and decontamination

$\mathrm{HNO}_{3} \quad$ Nitric acid

$\mathrm{H}_{2} \mathrm{C}_{2} \mathrm{O}_{4}$ Oxalic acid 


\section{WASTEWATER TREATMENT--THE EFFLUENT TREATMENT FACILITY}

\subsection{Function}

The Effluent Treatment Facility (ETF) collects, treats, and discharges all radioactively contaminated process wastewater from the High Level Waste Division.

\subsection{Description of the ETF Process}

A diagram of the ETF process is shown in Figure 9-1.

\subsubsection{Process Sewer and Treatment Plant}

Various generators discharge dilute wastewater streams into the process sewers, which drain by gravity to ETF's F\&H area lift stations, and are then pumped to the ETF Treatment Plant. The wastewater consists primarily of evaporator overheads from the Storage and Evaporation and the Separations facilities (Interface Stream 13).

The ETF treatment plant decontaminates the influent wastewater through a series of steps consisting of pH adjustment, sub-micron filtration, heavy metal and organic adsorption, reverse osmosis, and ion exchange. After the treatment steps remove specific species, the treated effluent is analyzed and discharged to the environment through a NPDES permitted outfall (H-016). ${ }^{32}$ The treatment steps concentrate the contaminants into a smaller volume of secondary waste, which is then further concentrated by evaporation. Various chemicals are used to restore the process efficiency (e.g., filter cleaning, ion exchange regeneration) and the spent solutions also seat to the evaporator. The ETF evaporator bottoms are then pumped to Tank $50 \mathrm{H}$ for eventual disposal in Saltstone.

Each step in the ETF treatment process has certain capabilities and certain vulnerabilities:

- The wastewater influeat is pH adjusted to maximize solids removal in the filter system. This adjustment is done continuously and also on a batch basis.

- The sub-micron filtration process removes suspended solids, but it can be overloaded by an excessive quantity of solids and can be fouled by certain types of suspended solids (e.g., bacteria). The filters are cleaned with oxalic acid, caustic, and chlorine (bleach). The feed can be treated with sluminum nitrate and/or ferric nitrate to reduce filter fouling.

- The resin used for heavy metal removal (e.g., mercury, lead) would be impacted by oxidizing agents (e.8., chlorine), and its effectiveness can depend on the species oxidation state (e.g., removes $\mathrm{Cr}^{+3}$, but not $\mathrm{Cr}^{+6}$ ). Excessive bacterin growths are removed by soaking the resin in caustic. After it becomes saturated, it is replaced. The spent resin is not a hazardous waste because it passes the EPA TCLP test.

- The activated carbon used for organic removal has a high capacity for some species (e.g., the TBP/NPH solveat used by Separations) and a lower capacity for others (e.g., phenol). If the influent wastewater contains an excessive quantity of some species (e.g., benzene) then the spent carbon disposal costs increase drastically (as a mixed waste). 


\section{Figure 9.1 Effluent Treatment Facility}

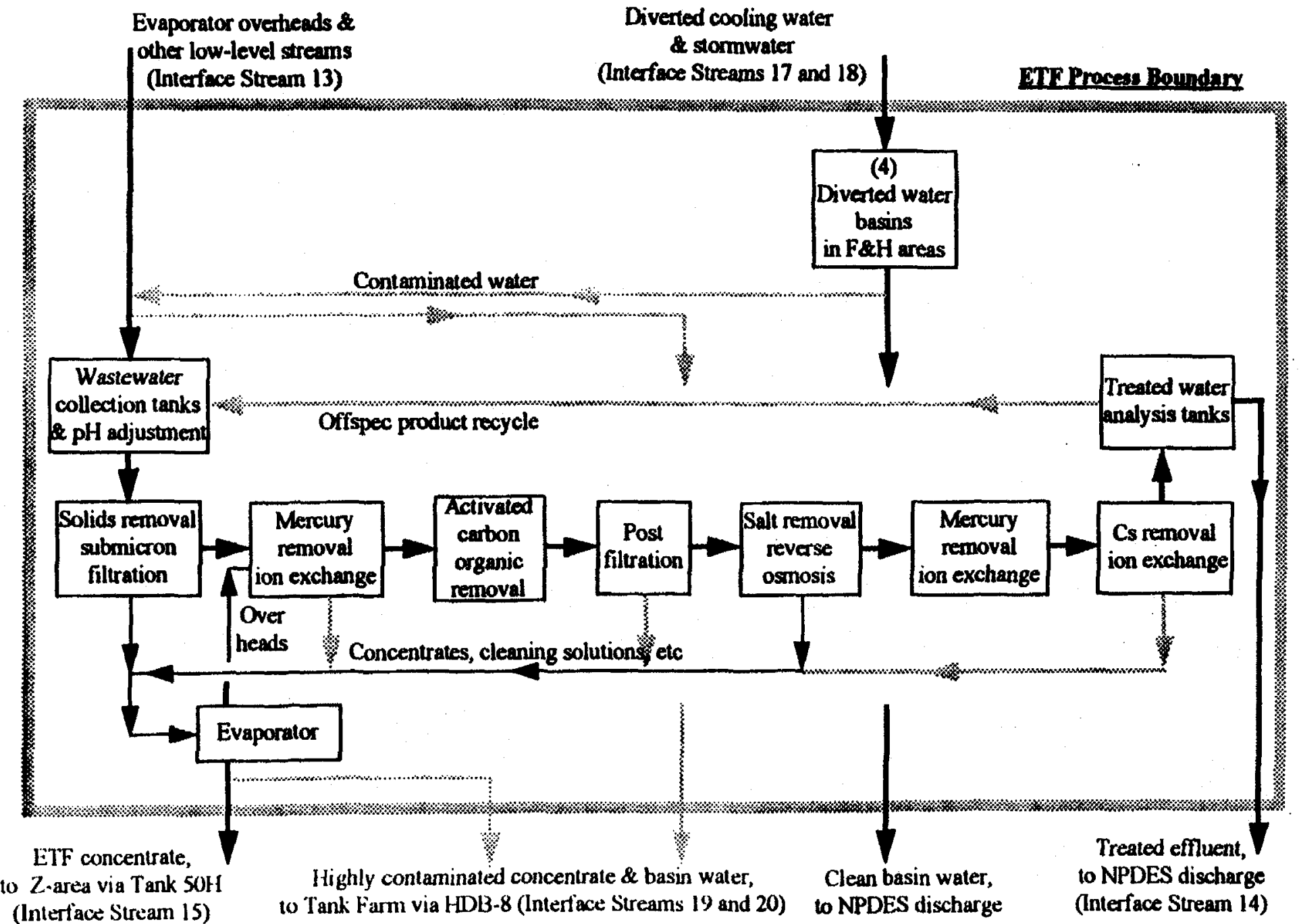


- The reverse osmosis step can be overlonded by the dissolved salts which it is removing, and its removal efficiency depends on the specific species (e.g., it is better on nitrate than on ammonia). The RO menbranes sre cleaned with oralic acid and/or caustic.

- The ion exchange resin used in the final treatment step is only effective on Cs-137. It is regenerated with a sodium nitrate solution at a frequency determined by the influent sodium content.

- In the ETF evaporator, most of the contaminant species go to the concentrate bottoms (to Tank 50H and then to Z-area), but a few species are volatile (e.g., metallic mercury, and ammonia if the $\mathrm{pH}$ isn't low enough).

The process sewer and treatment plant are operated in accordance with several SCDHEC Industrial Wastewater Facility permits. ${ }^{31}$

\subsubsection{Diverted Water Basins}

The Separations Department normally discharges its non-contact cooling water directly to the environment, after monitoring to ensure that it is not radioactively contaminated. Likewise, the Storage and Evaporation process, ESP, and ITP each monitor and discharge their uncontaminated storm water (which also includes small flows or noncontact steam condensate and cooling water). If any stream is contaminated, it is then diverted to one of ETF's four large lined basins which segregate the water based on its source and degree of contamination. There are also several administrative or precautionary reasons for the generators to divert the streams to the basins. In this report, the four basins are described generically; but specifically they are the F- and H-area "cooling water retention basins" and the "storm water \& excess cooling water retention basins" (although the italicized words are usually omitted).

The disposition of water which has been diverted to the basins is described in "9.3.2. Diverted Cooling Water and Diverted Storm Water--Interface Streams 17 and 18."

\subsection{Influent Streams and Key Process Variables}

\subsubsection{Evaporator Overheads and Other Low Level Streams-Interface Stream 13}

As described in "9.2.1. Process Sewer and Treatment Plant," each treatment step in the ETF process has a different removal efficiency for each contaminant species and the opention of some steps can be impaired by various species. This results in several methodologies that can determine the maximum influent concentration of each species:

- The maximum influent composition may be set by the discharge limitations (e.g., the NPDES permit, or DOE orders) in conjunction with the overall removal efficiencies. For many species, the overall process efficiency (typically $>95 \%$ ) determines the ETF influent limit. The notable exception is tritium, which is not removed at all (discounting the small fraction that goes to Saltstone).

- The allowable influent composition may be limited by the Z-area waste acceptance criteria, ${ }^{13}$ e.g., for chromium and gross beta/gamma. Most contaminants that are removed from the ETF influent are concentrated into the evaporator bottoms stream and go to Saltstone after temporary 
storage in Trak 50H. Thus, ETF's volume reduction factor (typically 50:1-100:1) limits the ETF influent to $1-2 \%$ of the Saltstone criteria.

- The limiting characteristic of some species is their impact on process operability, e.g. becteria/alge fouling of the sub-micron filters, or NaNO3 overloading the reverse osmosis units. For other species, the impact could be adsorbing enough contaminant that the secondary waste becomes a RCRA hazardous waste.

For each species, the ETF influent limit is set by the most restrictive of these methodologies.

The influeat species of concern are shown in table 9-1.

\section{Table 9-1}

\section{ETF Influent Parameter List}

Wastewater

Parameters

pH

Total Suspended Solids

ammonis

chlorino

Total Dissolved Solids

conductivity

oil \& grease

Biological Oxygen Demand

Volatile Organic Carbon

benzene

phenol

bacteria

\section{Chemical \\ Constituents}

$\mathrm{Hg}$

Cr

$\mathrm{Cu}$

$\mathrm{Pb}$

Zn

Si

Al

Fo

$\mathrm{NO}_{3}^{-}$

$\mathrm{Mn}$

U

$\mathrm{Ni}$

Ag

As

Ba

Cd

Se

$\mathrm{SO}_{4}$

CI
Radionctive

Constituents

groses alpha gross beta/gamm

tritium

Cs-137

The routine ETF wastewater influent consists primarily of overheads from various evaporation (about 90\%) in the F-and H-area Separations and Tank Farms. Other minor contributors are rainwater (less than 10\%), which collects in various dikes (for RCAs and for chemical tanks), and the Tritium facility lab waste and Tank Farm leak detoction catch tank (less than 1\%). The treatability of the routine process wastewater stream has been demonstrated by ETF's historical successful operation. Any proposed changes or additions are evaluated by HLWE on a case-by-case basis, sometimes requiring lab scale testing or SCDHEC approval. Such changes would include new streams piped to the process sewer or new contaminants (chemical or radionuclide) used in an existing process. 


\subsubsection{Diverted Cooling Water and Diverted Storm Water--Interface Streams 17 and 18}

As described in "9.2.2. Diverted Water Basins," cooling water and storm water cen be diverted to the ETF basins. Subsequent samople results frequently show that the diverted water actually meets the discharge limits and then it is discharged to a NPDES outfall (seo "9.4.3. Clean Basin Water").

Radionctively contaminated cooling water or storm water which has been diverted to the basins can be sent to the ETF treatment plant. Historically, such diversions occur infrequently, and the actual isotopes and concentrations depend on the source of contamination. This variety requires that HLWE evaluate each diversion on 2 case-by-case basis in order to determine proper handling.

Historically, the bacteria/algae in basin water has severely fouled the ETF filtration process. If the basin water were chemically contaminated, then SCDHEC requires that they approve specific plans for treatment.

With two additions, the methodologies described in "9.3.1. Evaporator Overheads and Other Low Level Streams-Interface Stream 13" also apply when evaluating the treatability of basin water. First, the treatment plant influent composition is limited by the allowable radiation dose rates, since the process equipmeat is essentially unshielded. Second, if the evapocator bottoms resulting from treatment of a particular basin water is too contaminated for Saltstone, then that concentrate can be sent to Storage and Evaporation via HDB-8 (see section "9.4.4. Highly Contaminated Basin Water-Interface Stream 19").

If the basin water is too highly contaminated for the treatment plant, then it will be sent to Storage and Evaponation via HDB-8 (see section "9.4.4. Highly Contaminated Basin Water--Interface Stream 19").

\subsubsection{Raw Materials and Lab Reagents}

Aluminum nitrate and/or ferric nitrate are used to improve filtration performnnce when needed, especially for high bacteria influents (e.g., basin water). Nitric acid is used for $\mathrm{pH}$ adjustment and to make sodium nitrate regenerant for the ion exchange step. Sodium hydroxide (caustic) is used for $\mathrm{pH}$ adjustment, to clean process equipment, to inhibit the ETF concentrate stream to meet Tank 50H corrosion requirements, and to make sodium nitrate regenerant for the ion exchange step. Both oxalic acid and bleach (dilute $\mathrm{NaOCl}$ ) are used to clean process equipment. After use, various ETF lab reagents are added into the ETF wastewater influent stream.

\subsubsection{Unusual and Unique Wastes}

HLWE will perform a case-by-case evaluation of each proposed waste stream using the same methodologies and criteria described in sections 9.3.1 and 9.3.2. Such evaluations will be reviewed and approved before waste is accepted. Laboratory testing and SCDHEC approval are likely to be required. Depending on the contaminant species, the waste can either be processed through the entire treatment sequence or it can be routed directly to the ETF evaporator. 
High-Lovel Wadte System Proceas Interfwce Deocription

\subsection{Effiuent Streams and Key Process Controls}

\subsubsection{Treated Effiuent-Interface Stream 14}

After the ETF influent is processed through the sequence of treatment steps described above, the treated effluent stream is analyzed and discharged through NPDES outfall H-016 to Upper Three Runs Creek. The effluent's chemical content is controlled by the ETF Wastewater Permit ${ }^{32}$ and the discharge radionuclide limits are set by DOE Order $5400.5^{33}$ and WSRC's ALARA program for effluent doses.

\subsubsection{ETF Concentrate--Interface Stream 15}

The contaminants which ETF removes from the influent stream are concentrated into $1-2 \%$ of the original volume. This evaporator bottoms concentrate is then pumped to Tank 5OH for eventual disposal in Saltstone, see Chapter 10. Sufficient corrosion inhibitor $(\mathrm{NaOH})$ is added to meet the ITP requirement (administratively, ITP operates Tank SOH). Other aspects of the stream composition are controlled by ITP's Process Requirements. As discussed in "9.3.1. Evaporator Overheads and Other Low Level Streams-Interface Stream 13," these Saltstone criteria are met by limiting the ETF influent composition.

Short term composition spikes will be blended into the large volume maintained in Tank 50H (50-1230 $\mathrm{Kgal})$, relative to the small flow from ETF (-5-20 Kgal/month for the past 5 years). Two slurry pumps have been installed in Tank $50 \mathrm{H}$ to ensure complete mixing. The minimum level in Tank $50 \mathrm{H}$ is controlled by the ITP Process Requirements, both to dampen out composition swings and to allow adequate cooling for ETF's high temperature concentrate.

If the radioactive contamination level is too high for Saltstone, then the concentrate will be sent to Storage and Evaporation via HDB-8 (not yet in service), see section "9.4.4. Highly Contaminated Basin Water-Interface Stream 19." If the chemical content is unsuitable for Saltstone, then SCDHEC approval is needed for any alternate disposition.

\subsubsection{Clean Basin Water}

As described "9.3.2. Diverted Cooling Water and Diverted Storm Water-Interface Streams 17 and 18," cooling water or storm water which has been diverted to the ETF basins is analyzed. Frequently the basin water is suitable for discharge through a NPDES outfall (F-012, F-013, H-017, or H-018 depending on the particular basin) to Four Mile Creek, in accordance with the ETF Wastewater Permit. ${ }^{32}$ The discharge radionuclide limits are set by DOE Order $5400.5^{33}$ and the WSRC ALARA program for effluent doses.

\subsubsection{Highly Contaminated Basin Water--Interface Stream 19}

If the radioactive content of the basin water is too high for the ETF treatment plant, then it will be sent to Storage and Evaporation via HDB-8 (not yet in service). Due to the variety of compositions possible, such routing will be evaluated by HLWE on a case-by-case basis. A suitable amount of corrosion inhibitor ( $\mathrm{NaOH}$ and/or $\mathrm{NaNO}_{2}$ ) would have to be added at some point in the transfer. A large volume of contaminated water would probably be involved in any diversion and could consume a large fraction of the Tank Farm's spare volume available. 
If the chemical conteat of the besin water is unsuitable for ETF, then SCDHEC approval is needed for any alternate disposition.

\subsubsection{Highly Contaminated Eyaporator Bottoms--Interface Stream 20}

If the radionctive content of the ETF evaporator bottoms is too high for Saltstone, then it will be sent to Storage and Evaporation via HDB-8 (not yet in service). Due to the variety of compositions possible, such routing will be evaluated by HLWE on a case-by-case basis. The normal amount of corrosion inhibitor $(\mathrm{NaOH})$ added to the concentrate would suffice (see "5.3.2.1. Requirements for Corrosion Prevention.").

If the chemical content of the ETF eveporator bottoms is unsuitable for Saltstone, then SCDHEC approval is needed for any alternate disposition.

\section{SOLIDIFICATION AND DISPOSAL (DWPF SALTSTONE)}

\subsection{Function}

The Saltstone Production Facility (SPF) and the Saltstone Disposal Facility (SDF) are both located in ZArea at the SRS. These Z-Aree facilitiea are used to: 1) process aquecus salt solution waste in the SPF in a safe and environmentally sound menner to generate a Low-Level Waste grout-like wasteform known as Saltstone; and 2) dispose of Saltstone in a safe and environmentally sound manner by placing the Saltstone in concrete vaults that are located in the SDF. Controls are imposed on waste sent to Z-Area to limit the hazards of operating $Z$ area and to ensure that the cured Saltstone is non-hazardous.

\subsection{Description of the Saltstone Production and Disposal Process}

In the Saltstone Production Facility, aqueous salt solution is received from Tank 50H and is then combined with a blend of cement, flyash and blest-fumace slag to generate nonhazardous LLW Saltstone (Fig. 10-1). The Saltstone grout is pumped through a pipeline from the Saltstone Production Facility to a covered cell of an above-grade, concrete vault located in the Saltstone Disposal Facility. The grout solidifies into a monolithic, nonhazardous solid waste called Saltstone. No aqueous waste streams are released directly to the environment or sent to other facilities from Z-Area.

\subsubsection{Saltstone Production Facility $34,38,30$}

\subsubsection{Equipment}

Major equipment componeats of the Saltstone Production Facility include: (1) bulk storage silos for dry feeds; (2) dry feed blending and transfer equipment that includes the Premix Feed Bin; (3) the Salt Solution Hold Tank (SSHT) that receives aqueous salt solution to be processed; (4) the Flush Water Receipt Tank (FWRT) that receives equipment flushes and liquids collected in sumps located in Z-Area; (5) a Mixer that blends waste solution (and flush water, when nocessary) with dry feeds to produce nonhazardous Saltstone grout; (6) a Saltstone Hold Tank (SHT) that provides a reservoir of grout to prevent cavitation of the grout pumps; (7) grout pumps; and (8) pipelines that are used to transfer salt solutions, flush water and Saltstone grout within the production facility and grout to the disposal vaults. 


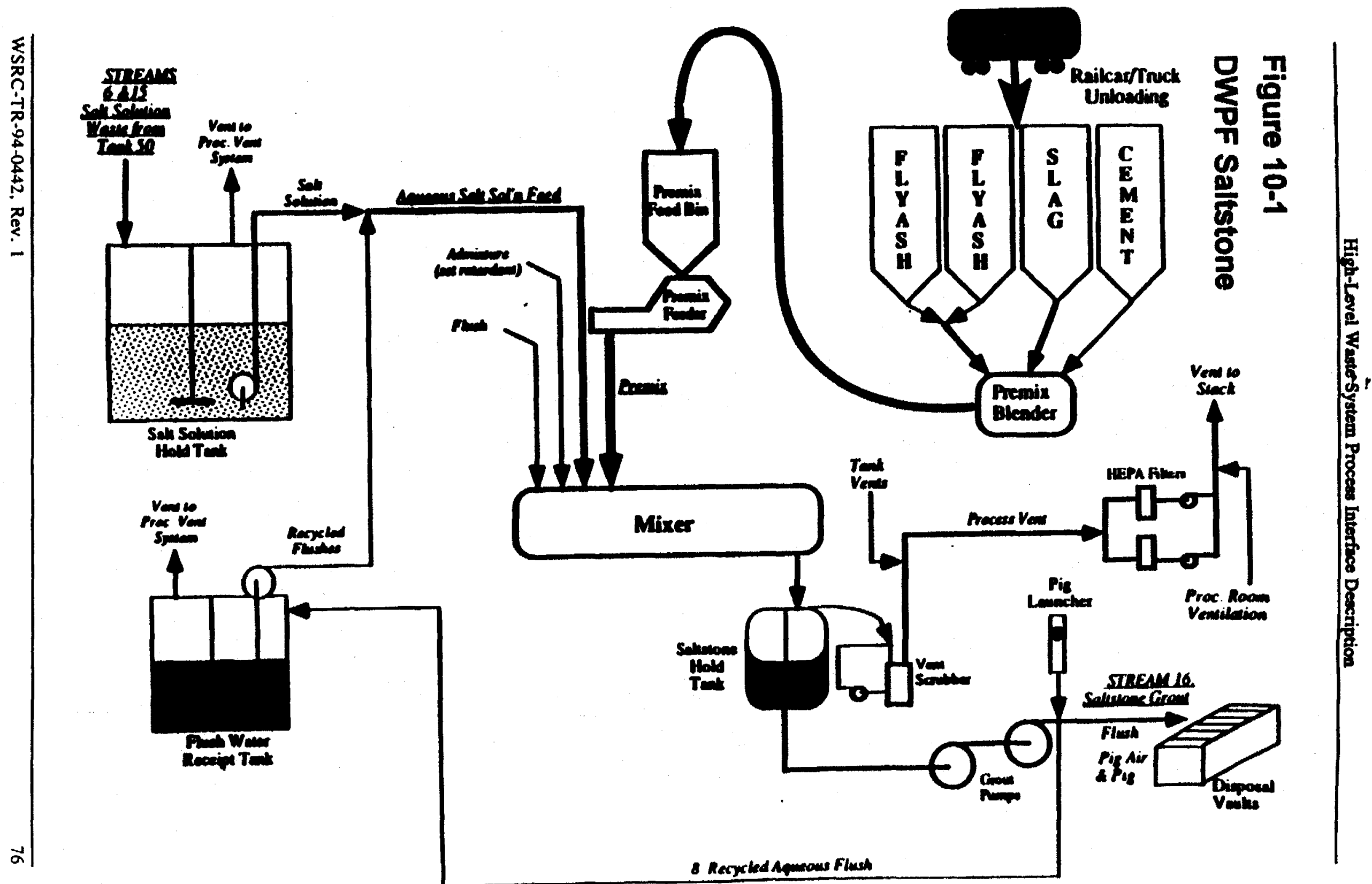




\subsubsection{Waste Receips}

As presently permitted, all aqueous waste sent to Z-Area from waste generators must first be transferred to Tank 50H, a 1.3-million gallon tank localod in the H-Area Tank Farm. Tank 50H thus forms the physical interface between Z-Area and waste generators. Salt solutions from other HLW treatment operations in the Effluent Treatment Facility (ETF) and the In-Tank Precipitation Process are transferred to Tank 50H. Salt solution is then transferred from Tank 50H to Z-Area through the H-to-Z Interarea Transfer Line, an underground pipeline that is designed to maintain double containment of any waste transferred through the line.

\subsubsection{Process}

The Saltstone production process is simple. Dry feed materials are blended automatically in the desired ratio and transferred pneumatically to the Premix Feed Bin. Premix is then fed at a preset rate to the Mixer. Salt solution is also fed to the Mixer where it is mixed with the premix to produce Saltstone grout. The grout is then pumped to the disposal vaults. Except for special design considerations and operating procedures because of the presence of low levels of radionuclides, the process is identical to a concrete batch plant.

Since the Salt Solution Hold Tank and the Flush Water Receipt Tank can contain potentially hazardous contaminants and radioactive contaminants, both tanks are isolated from the immediate environment by secondary containment (concrete dikes). Because Z-Are fecilities are designed to allow contact maintenance, radioactive contaminants in waste sent to Z-Area must be sufficiently low to prevent excessive radiation exposure to workers in Z-Area.

\subsubsection{Saltstone Disposal Facility ${ }^{37,38}$}

Because Saitstone is nonhazardous, the Saltstone Disposal Facility is designed as a "controlled release" landfill disposal site. The only long-term potential risk to the environment and to the general public is through possible degradation of surfece water or groundwater quality due to a release of chemical or radioactive pollutants from the SDF into surface streams or into the underlying groundwater. Such releases are mitigated by the surrounding concrete vaults and the Saltstone waste form, itself. Final site closure will further mitigate the potential long-term risk to the eavironment. Monitoring wells are installed in accord with permit requirements to periodically monitor the groundwater for contaminants that could be released from the SDF.

\subsubsection{Disposal Opentions Prior to Closure}

The low concentration of gamma-emitting isotopes specified for Saltstone allows a delay of backfilling operations at the Saltstone Disposal Facility. Minimal backfilling around the vaults prior to final closure operations is planned, principally to control surface water runoff and erosion. Thus the Saltstone Disposal Facility will consist of above-grade vaults during active disposal operations.

Aqueous waste from sampling and laboratory testing in Z-Area are sent to the FWRT and subsequently processed as a part of normal Saltstone production. Solid samples from laboratory testing and failed equipment from the Saltstone Production Facility are simply pleced in a disposal vault and covered with Saltstone from continuing production operations, eliminating the need to transfer a significant quantity of solid waste to another disposal site. Job control waste from maintenance and production operation in radiologically controlled areas (shoe covers, gloves, plastic sheeting, etc.) is the only solid waste generated in Z-Area that must be sent to another facility for treatment and disposal. 


\subsubsection{Site Closine}

Final closure operations at the Z-Area site will not begin until most (or all) of the vaults have been filled with Saltstone and capped with a layer of clean grout. As presently conceived, the overall site closure concept is designed to minimize water infiltration through the vaults that could transport potential contaminants from the vaults into underlying groundwater.

Key elements of the closure concept include buckfilling with native soil, placement of a clay cap over the site to minimize infiltration to the vaults, and placing a gravel layer above the clay cap. The gravel layer will reduce the hydrostatic head and provide a capillary break above the clay cap to minimize infiltration through the cap. A geotextilo fabric will be placed over the gravel layer to minimize infiltration of fineparticle soil into the gravel layer from additional native soil that will be placed over the gravel layer. Shallow-rooted bamboo, a terminal vegetation recommended by the U. S. Soil Conservation Service, will be planted on the site to minimize encroschment by deep-rooted plants such ss pine trees whose roots could penetrate the clay cap and thus increase infiltration through the waste.

\subsection{Influent Stream and Key Process Variables--Interface Stream 6}

As noted in Section 10.1, Tank SOH is the physical interface between Z-Area and the rest of the HLW System. Accordingly, additions to and the contents of Tank $50 \mathrm{H}$ must be monitored to assure that aqueous waste sent to Z-Area is within waste acceptance criteria for Z-Ares.9.7 Presently, aqueous waste is transferred to Tank 5OH from the Effluent Treatment Facility (Interface Stream 15) and the InTank Precipitation Process (Interface Stream 5). Both operations (and Tank 50H) are geographically located in H-Area. Administratively, Z-Area assumes responsibility for the aqueous waste when it enters the SSHT. . $^{36,36}$

Salt solution sent to Z-Area (Interface Stream 6) can contain low levels of hazardous substances. However, concentrations of these contaminants must be sufficiently low to assure that non-hwzardous Saltstone, as defined by regulatory agencies, can be produced. Controls ${ }^{19}$ are imposed on additions to Tank 50H to assure that the aqueous waste will meet waste acceptance criteria for regulatory and i ingterm performance requirements. ${ }^{34,36}$ Changes to these controls require review and approval by the $Z$ Area Facility Manager.

Because of limited radiation shielding in the SPF, additional restrictions are imposed on generators to minimize the concentration of radiosctive contaminants that emit high-energy gamma radiation. Present waste acceptance criteria specify limits for Co-60, Ru-106, Sb-125, Cs-137 and Eu-154, since these species have been ideatified as potential contaminants in aqueous waste from the ETF and ITP. Significant concentrations of other gamma-emitting contaminants in aqueous waste must be reviewed for possible impactu on radiological safety in Z-Area before the waste can be sent to Z-Area for treatment and disposal.

Limits imposed by Saltstone require that the $\mathrm{pH}$ of the waste be greater than 10 and the temperature of the solution be less than 40 degrees C. Contaminants that are monitored by generators in waste transferred to $\mathrm{Z}$ Area are listed below: 


\section{Table 10-1 \\ Saltstone Influent Parameter List}

$\begin{array}{lll} & \text { MAJOR } & \text { MNNOR CHIM } \\ \text { BADIONUCLIDES } & \text { CHEMICALS } & \text { AND META } \\ \text { H-3 } & \text { Hydroxide } & \text { Benzene } \\ \text { C-14 } & \text { Nitrate } & \text { Phenol } \\ \text { Ni-59 } & \text { Nitrite } & \text { Isopropenol } \\ \text { Ni-63 } & \text { Carbonate } & \text { Methanol } \\ \text { Co-60 } & \text { Oxalate } & \text { Arsenic } \\ \text { Sr-89/90 } & \text { Sulfate } & \text { Barium } \\ \text { Tc-99 } & \text { Fluoride } & \text { Cadmium } \\ \text { Ru-106 } & \text { Chloride } & \text { Chromium } \\ \text { Sb-125 } & \text { Phosphate } & \text { Lead } \\ \text { I-129 } & \text { Tetraphenylborate } & \text { Mercury } \\ \text { Cs-137 } & \text { Aluminate } & \text { Selenium } \\ \text { Eu-154 } & & \text { Silver } \\ \text { Pu-241 } & & \\ \text { Total Beta/Gamm } & & \\ \text { Total Alpha } & & \end{array}$

The limits in the Test Authorization and WAC are set at levels that assure: 1) permits for Z-Area operations will not be violated and 2) safety of Z-Aren operations and long-term performance will not be compromised. Waste generators must provide evidence of compliance with limits before salt solution can be transferred to Z-Area for processing.

Any significant waste components not specifically covered in current waste acceptance criteria must be tested for regulatory compliance prior to introducing such components into salt solution sent to Tank 50H and ultimately to Z-Area. The significance of a new waste component is established by: 1) potential process hazard (chemical or radiological) to Tank $50 \mathrm{H}$ or Z-Area operations; 2) regulatory concern from an environmental release; 3) inability to produce non-hazardous Saltstone, as defined by EPA and state regulations (Saltstone samples must be prepared and tested, using a range of concentrations of a new contaminant, to establish limits for the contaminant); or 4) a chemical specifically added by a waste generator as a result of a new or changing process in sufficient concentration to impact the properties of Saltstone.

Any changes to the waste acceptunce criteria for salt solution transferred to Z-Area requires technical review by HLW Engincering and approval of the HLW Level 2 Manager. Because facilities in Z-Area are permitted by the state of South Carolina, salt solution containing any significant waste components not previously ideatified in permit applications submitted to SCDHEC cannot be sent to Z-Area for treatment and disposal without prior approval by SCDHEC. 


\subsection{Effluent Stream and Key Process Controls--Interface Stream 16}

Saltstone must be formulated to meet permit and long-term performance requiremeats. As notod in Section 10.3, a broad range of dry material compositions have been demonstrated to yield an acceptable Saltstone product. However, certain restrictions are imposed on the SPF process to assure Saltstone with the required properties is produced:

1. Sufficieat dry material must be added to the aqueous waste during the production of Saltstone to assure that the presence of free liquids in a vault does not exceed $t$ vol $\%$ of the total waste volume at the time of vault closure.

2. Hazardous waste, as defined by SCDHEC (and the EPA), cannot be placed in the SDF for disposal.

3. The temperature of the Saltstone during curing in the vault cannot exceed 90 degrees centigrade to assure long-term integrity of the Saltstone.

4. Radioactive contaminants in the waste must be "as low as reasonably achievable" (ALARA) and in no case should the concentration of individual radiaactive contaminants exceed the limits specified by the Nuclear Regulatory Commission (NRC) for Class C LLW. WSRC has imposed a goal to assure that the overall average concentration of individual radioactive contaminants in the waste placed in the SDF shall not exceed the limits specified by the NRC for Class A waste.

Testing, procedures, and limits imposed on waste generators and in the SPF for the production and disposal of Saltstone must assure these conditions are met. To confirm these conditions are being met, periodic sampling of Saltstone grout and subsequent testing of cured Saltstone produced from the samples of grout is required.

Based on results from tests on various ratios of waste components and dry materials, the above restrictions will always be met with salt solution that meets the Waste Acceptence Criteria , providing the temperature of grout sent to a disposal vault is acceptable.

\subsection{Raw Materials}

Materials used in the production of Sultstone are obtained from off-site vendors. To produce Saltstone from aqueous waste requires the addition of a blend of cementitious dry materials. If necessary, a set retardant can also be added to facilitate production in the SPF and subeequent pouring of Saltstone grout into a vault cell in the SDF.

A blend of dry materials is prepared in the SPF by combining a lime source, Class F fly ash, and blastfurnace slag. Either calcium hydroxide or Class II Portland cement can be used as the lime source in the Saltstone formulation. 


\section{CONTROL OF HLW PROCESS INTERFACES}

This chapter describes HLW Process interfaces in the HLW System. The PID identifies 20 interfaces that are the basis for control of the HLW System (See Figures 4-1 and 4-2). These interfaces have already been described in the previous six chapters discussing each HLW Process. However, the information about a specific interface is usually in two places (e.g., the Extended Sludge Processing chapter describes how washed sludge is prepared, whereas the information on why the composition of this washed sludge must be controlled is in the Vitrification chapter). This chapter is organized by interfaces, and identifies the required interface control documents for each interface.

The eight tables that follow describe all the significant interfaces in the high-level waste system. Table 11-1 describes generic interfaces that apply to all HLW Processes. Tables 11-2 through 11-7 describe the interfaces specific to each of the HLW Processes. All process interfeces are listed, i.e. streams that contact the process. Streams that don't contect the process, such as instrumeat air, cooling water, etc., are not listed. If the interface is controlled within the HLW System, then the table describes the basis for that control. If the interface is one that is within the scope of the PID, then the "Basis for Control" column says, "Interface Stream NN (Table 11-8)," where NN is the interface stream number. Look in Table 11-8 for more information.

All the identified interface streams are described in order in Table 11-8. The required interface control documents for each stream are listed. The documents listed are the primary documeats that regulate the interface (i.e. there will always be procedures and other documents that support the primary documents, but the PID concentrates on the primary agreements between the two affected processes). 
Table 11-1: Generic Interfaces That Apply To All HLW Processes

\begin{tabular}{|c|c|c|c|c|}
\hline Stream & From & To & $\begin{array}{l}\text { Within Scope } \\
\text { Of PID? }\end{array}$ & Basis for Control \\
\hline $\begin{array}{l}\text { Raw Materials } \\
\text { (Including } \\
\text { Laboratory } \\
\text { Reagents) }\end{array}$ & Vendors & $\begin{array}{l}\text { Any HLW } \\
\text { Process }\end{array}$ & $\begin{array}{l}\text { Only For New } \\
\text { Chemicals }\end{array}$ & $\begin{array}{l}\text { Essential Material Specifications or other controls in HLW Process technical baseline. } \\
\text { Most changes to these will be handled at the HLW Process level. However, any now } \\
\text { process chemicals to be added to any HLW Process are considered a change to the } \\
\text { Process Interface Description and must be reviewed at that lovel. Labontory reagents } \\
\text { are reviewed for level of risk. }\end{array}$ \\
\hline Water & Power & $\begin{array}{l}\text { Any HLW } \\
\text { Process }\end{array}$ & No & Controlled By Power Depertment Procedures \\
\hline $\begin{array}{l}\text { Unusual and } \\
\text { Unique Wastes }\end{array}$ & Any generatior & Any facility & Yes & $\begin{array}{l}\text { All unusual and unique wastes must be reviewed by the receiving HLW Process. If } \\
\text { the waste will be received in a normal receipt point, then the interface control for } \\
\text { interface applies. If the waste will be received in an unusual place, the management } \\
\text { of that HLW Process is responsible for reviewing the waste versus the interface } \\
\text { control documents and the PID. }\end{array}$ \\
\hline Solid Waste & $\begin{array}{l}\text { Any HLW } \\
\text { Process }\end{array}$ & $\begin{array}{l}\text { Solid Waste } \\
\text { Disposal HLW } \\
\text { Process }\end{array}$ & No & $\begin{array}{l}\text { Controlled by Solid Waste Disposal Waste Acceptance Criteria and HLW Process } \\
\text { Waste Compliance Plans }\end{array}$ \\
\hline Air Emissions & $\begin{array}{l}\text { Any HLW } \\
\text { Process }\end{array}$ & Atmosphere & No & Controlled by permits \\
\hline $\begin{array}{l}\text { Unmonitored } \\
\text { Stormwater } \\
\text { And Cooling } \\
\text { Water (Not } \\
\text { Monitored For } \\
\text { Radioactivity } \\
\text { Before } \\
\text { Release) }\end{array}$ & $\begin{array}{l}\text { Any HLW } \\
\text { Process }\end{array}$ & Outfall & No & Controlled by permits or uncontrolled \\
\hline
\end{tabular}




\begin{tabular}{|l|l|l|l|l|}
\hline Stream & From & To & $\begin{array}{l}\text { Within Scope } \\
\text { Of PID? }\end{array}$ & Basis for Control \\
\hline $\begin{array}{l}\text { Samples To } \\
\text { Analytical } \\
\text { Laboratories }\end{array}$ & $\begin{array}{l}\text { Any HLW } \\
\text { Process }\end{array}$ & Laboratories & No & Controlled By Site Manuals and Analytical Procedures \\
\hline $\begin{array}{l}\text { Groundwater } \\
\text { Egress From } \\
\text { HLW Process }\end{array}$ & $\begin{array}{l}\text { Any HLW } \\
\text { Process }\end{array}$ & Groundwater & No & $\begin{array}{l}\text { May be controlled by Permits and may impact interface documents that are within the } \\
\text { scope of the PID (e.g. Saltstone). }\end{array}$ \\
\hline
\end{tabular}


Table 11-2: Storage and Evaporation Interfaces

\begin{tabular}{|c|c|c|c|c|}
\hline Stream & From & To & $\begin{array}{l}\text { Within Scope } \\
\text { Of PID? }\end{array}$ & Basis for Control \\
\hline $\begin{array}{l}\text { Generic } \\
\text { Streams (See } \\
\text { Table 11-1) }\end{array}$ & Any generator & -1 & & See Table 11-1 \\
\hline $\begin{array}{l}\text { Incoming } \\
\text { Wastes }\end{array}$ & $\begin{array}{l}\text { Waste } \\
\text { Generators } \\
\text { (Including } \\
\text { WM } \\
\text { Maintenance } \\
\text { Facility, } \\
\text { 299-H) } \\
\end{array}$ & $\begin{array}{l}\text { Storage and } \\
\text { Evaporation }\end{array}$ & Yes & Interface Stream 1 (See Table 11-8) \\
\hline $\begin{array}{l}\text { Spent } \\
\text { Washwater } \\
\text { From Sludge } \\
\text { Processing } \\
\end{array}$ & $\begin{array}{l}\text { Sludge } \\
\text { Processing }\end{array}$ & $\begin{array}{l}\text { Storage and } \\
\text { Evaporation }\end{array}$ & Yes & Interface Stream 3 (See Table 11-8) \\
\hline $\begin{array}{l}\text { DWPF } \\
\text { Recycle }\end{array}$ & Vitrification & $\begin{array}{l}\text { Storage and } \\
\text { Evaporation }\end{array}$ & Yes & Interface Stream 10 (Soe Table 11-8) \\
\hline $\begin{array}{l}\text { Highly } \\
\text { Contaminated } \\
\text { Stormwater Or } \\
\text { Cooling Water }\end{array}$ & ETF Basins & $\begin{array}{l}\text { Storage and } \\
\text { Evaporation }\end{array}$ & Yes & Interface Stream 19 (See Table 11-8) \\
\hline $\begin{array}{l}\text { Highly } \\
\text { Contaminated } \\
\text { ETF } \\
\text { Concentrate }\end{array}$ & $\begin{array}{l}\text { ETF } \\
\text { Treatment } \\
\text { Plent }\end{array}$ & $\begin{array}{l}\text { Storage and } \\
\text { Evaporation }\end{array}$ & Yes & Interface Stream 20 (Soe Table 11-8) \\
\hline
\end{tabular}




\begin{tabular}{|c|c|c|c|c|}
\hline Stream & From & To & $\begin{array}{l}\text { Within Scope } \\
\text { Of PID? }\end{array}$ & Basis for Control \\
\hline Sludge & $\begin{array}{l}\text { Storage and } \\
\text { Evaporation }\end{array}$ & $\begin{array}{l}\text { Sludge } \\
\text { Processing }\end{array}$ & Yes & Interface Stream 2 (Soe Table 11-8) \\
\hline Salt Solution & $\begin{array}{l}\text { Storage and } \\
\text { Evaporation }\end{array}$ & $\begin{array}{l}\text { In-Tank } \\
\text { Precipitation }\end{array}$ & Yes & Interface Stream 5 (See Table 11-8) \\
\hline $\begin{array}{l}\text { Evaporator } \\
\text { Overheads }\end{array}$ & $\begin{array}{l}\text { Storage and } \\
\text { Evaporation }\end{array}$ & ETF & Yes & Interface Stream 13 (See Table 11-8) \\
\hline $\begin{array}{l}\text { Diverted } \\
\text { Stormwater } \\
\text { From } \\
\text { Monitored } \\
\text { Zones } \\
\end{array}$ & $\begin{array}{l}\text { Storage and } \\
\text { Evaporation }\end{array}$ & ETF Basins & Yes & Interface Stream 17 (Soe Table 11-8) \\
\hline $\begin{array}{l}\text { Monitored } \\
\text { Stormwater } \\
\text { That Is Clean }\end{array}$ & $\begin{array}{l}\text { Storage and } \\
\text { Evaporation }\end{array}$ & Outfall & No & Storage and Evaporation Procedures \\
\hline $\begin{array}{l}\text { Wastewater } \\
\text { Used For } \\
\text { Washing }\end{array}$ & $\begin{array}{l}\text { Storage and } \\
\text { Evaporation } \\
\text { (Originally } \\
\text { comes from } \\
\text { RBOF, DWPF } \\
\text { Recycle, } \\
\text { Others) } \\
\end{array}$ & $\begin{array}{l}\text { Sludge } \\
\text { Processing }\end{array}$ & No & $\begin{array}{l}\text { Controlled by Sludge Processing Baseline. Any stream is acceptable as long as } \\
\text { Extended Sludge Processing baseline and downstream interface requirements can be } \\
\text { met. }\end{array}$ \\
\hline $\begin{array}{l}\text { Mercury From } \\
\text { Evaporators }\end{array}$ & $\begin{array}{l}\text { Mercury } \\
\text { Collection } \\
\text { Tanks and } \\
\text { HLW } \\
\text { Evaporators }\end{array}$ & $\begin{array}{l}\text { Separations } \\
\text { Canyons }\end{array}$ & No & $\begin{array}{l}\text { Controlled by Storage and Evaporation Baseline. Stream is very low volume } \\
\text { (maximum of a few liters per months from all evaporators combined), e.g. } \\
\text { comparable to Laboratory steams, which are controlled outside of scope of PID. }\end{array}$ \\
\hline
\end{tabular}


Table 11-3: In-Tank Precipitation (ITP) Interfaces

\begin{tabular}{|c|c|c|c|c|}
\hline Stream & From & To & $\begin{array}{l}\text { Within Scope } \\
\text { Of PID? }\end{array}$ & Basis for Control \\
\hline $\begin{array}{l}\text { Generic } \\
\text { Streams (See } \\
\text { Table 11-1) }\end{array}$ & Any generator & & & See Table 11-1 \\
\hline Salt Solution & $\begin{array}{l}\text { Storage and } \\
\text { Evaporation }\end{array}$ & $\begin{array}{l}\text { In-Tank } \\
\text { Precipitation }\end{array}$ & Yes & Interface Stream 5 (See Table 11-8) \\
\hline $\begin{array}{l}\text { Spent } \\
\text { Washwater }\end{array}$ & $\begin{array}{l}\text { Vitrification } \\
\text { (Lete Wash) }\end{array}$ & $\begin{array}{l}\text { In-Tunk } \\
\text { Procipitation }\end{array}$ & Yes & Interface Stream 8 (See Table 11-8) \\
\hline $\begin{array}{l}\text { ETF } \\
\text { Concentrate }\end{array}$ & $\begin{array}{l}\text { ETF } \\
\text { Treatment } \\
\text { Plant } \\
\end{array}$ & $\begin{array}{l}\text { ITP (Tank } \\
\text { 50H) }\end{array}$ & Yes & Interface Stream 15 (See Table 11-8) \\
\hline Saltstone Feed & $\begin{array}{l}\text { ITP (Tank } \\
50 \mathrm{H})\end{array}$ & Saltstone & Yes & Interface Stream 6 (See Table 11-8) \\
\hline $\begin{array}{l}\text { Partially } \\
\text { Washeal } \\
\text { Procipitate }\end{array}$ & $\begin{array}{l}\text { In-Tank } \\
\text { Precipitation }\end{array}$ & $\begin{array}{l}\text { Vitrification } \\
\text { (Late } \\
\text { Washing) } \\
\end{array}$ & Yes & Interface Stream 7 (See Table 11-8) \\
\hline $\begin{array}{l}\text { Diverted } \\
\text { Stormwater } \\
\text { From } \\
\text { Monitored } \\
\text { Zones In ITP } \\
\text { (Part of Tank } \\
\text { Farm system) }\end{array}$ & $\begin{array}{l}\text { Runoff From } \\
\text { In-Tank } \\
\text { Precipitation } \\
\text { Tanks }\end{array}$ & ETF Basins & Yes & Interface Stream 17 (See Table 11-8) \\
\hline $\begin{array}{l}\text { Monitored } \\
\text { Stormwater } \\
\text { That Is Clean }\end{array}$ & $\begin{array}{l}\text { Runoff From } \\
\text { In-Tank } \\
\text { Procipitation } \\
\text { Tanks }\end{array}$ & Outfall & No & Tank Farm and ITP Procedures \\
\hline
\end{tabular}


Table 11-4: Extended Sludge Processing (ESP) Interfaces

\begin{tabular}{|c|c|c|c|c|}
\hline Stream & From & To & $\begin{array}{l}\text { Within Scope } \\
\text { Of PID? }\end{array}$ & Basis for Control \\
\hline $\begin{array}{l}\text { Generic } \\
\text { Streams (See } \\
\text { Table 11-1) } \\
\end{array}$ & Any generator & & & See Table 11-1 \\
\hline Sludge & $\begin{array}{l}\text { Storage and } \\
\text { Evaporation }\end{array}$ & $\begin{array}{l}\text { Sludge } \\
\text { Processing }\end{array}$ & Yes & Interface Stream 2 (See Table 11-8) \\
\hline $\begin{array}{l}\text { Wastewater } \\
\text { Used For } \\
\text { Washing }\end{array}$ & $\begin{array}{l}\text { Storage and } \\
\text { Evaporation } \\
\text { (Originally } \\
\text { Comes From } \\
\text { RBOF, DWPF } \\
\text { Recycle, } \\
\text { Others) } \\
\end{array}$ & $\begin{array}{l}\text { Sludge } \\
\text { Processing }\end{array}$ & No & $\begin{array}{l}\text { Controlled by Sludge Processing Baseline. Any stream is acceptable as long as } \\
\text { Extended Sludge Processing baseline and downstream interface requirements can be } \\
\text { met }\end{array}$ \\
\hline $\begin{array}{l}\text { Spent } \\
\text { Washwater }\end{array}$ & \begin{tabular}{|l} 
Sludge \\
Processing \\
\end{tabular} & $\begin{array}{l}\text { Storage and } \\
\text { Evaporation }\end{array}$ & Yes & Interface Stream 3 (See Table 11-8) \\
\hline $\begin{array}{l}\text { Washed } \\
\text { Sludge }\end{array}$ & $\begin{array}{l}\text { Sludge } \\
\text { Processing }\end{array}$ & DWPF Glass & Yes & Interface Stream 4 (See Table 11-8) \\
\hline $\begin{array}{l}\text { Diverted } \\
\text { Stormwater } \\
\text { From } \\
\text { Monitored } \\
\text { Zonies ln } \\
\text { Sludge } \\
\text { Processing } \\
\text { (Part Of Tank } \\
\text { Farm System) }\end{array}$ & $\begin{array}{l}\text { Sludge } \\
\text { Processing } \\
\text { Tanks }\end{array}$ & ETF Basins & Yes & Interface Stream 17 (See Table 11-8) \\
\hline $\begin{array}{l}\text { Monitored } \\
\text { Stormwater } \\
\text { That Is Clean }\end{array}$ & $\begin{array}{l}\text { Runoff From } \\
\text { Sludge } \\
\text { Processing } \\
\text { Tanks }\end{array}$ & Outfall & No & Tank Farm and ESP Procedures \\
\hline
\end{tabular}


Table 11-5: DWPF Late Wash, Pretreatment, and Vitrification Interfaces

\begin{tabular}{|c|c|c|c|c|}
\hline Stream & From & To & $\begin{array}{l}\text { Within Scope } \\
\text { Of PID? }\end{array}$ & Basis for Control \\
\hline $\begin{array}{l}\text { Generic } \\
\text { Streams (See } \\
\text { Table 11-1) }\end{array}$ & Any generator & & & Soe Table 11-1 \\
\hline $\begin{array}{l}\text { Washed } \\
\text { Sludge }\end{array}$ & $\begin{array}{l}\text { Sludge } \\
\text { Processing }\end{array}$ & Vitrification & Yes & Interface Stream 4 (Soe Table 11-8) \\
\hline $\begin{array}{l}\text { Partially } \\
\text { Washed } \\
\text { Procipitate }\end{array}$ & $\begin{array}{l}\text { In-Tank } \\
\text { Precipitation }\end{array}$ & $\begin{array}{l}\text { Vitrification } \\
\text { (Late Wash) }\end{array}$ & Yes & Interface Stream 7 (See Table 11-8) \\
\hline Canisters & Vendors & Vitrification & No & $\begin{array}{l}\text { Waste Acceptance Product Specifications } \\
\text { DWPF Vendor Specifications }\end{array}$ \\
\hline $\begin{array}{l}\text { Spent } \\
\text { Washwater } \\
\text { (Including } \\
\text { Cleaning } \\
\text { Solutions And } \\
\text { Lab Waste) }\end{array}$ & $\begin{array}{l}\text { Vitrification } \\
\text { (Late Wash) }\end{array}$ & $\begin{array}{l}\text { In-Tank } \\
\text { Precipitation }\end{array}$ & Yes & Interface Stream 8 (Soe Table 11-8) \\
\hline $\begin{array}{l}\text { Canistered } \\
\text { Glass Waste } \\
\text { Form }\end{array}$ & Vitrification & Repository & Yes & Interface Stream 9 (See Table 11-8) \\
\hline $\begin{array}{l}\text { DWPF } \\
\text { Recycle } \\
\text { (lacluding } \\
\text { Cleaning } \\
\text { Solutions And } \\
\text { Lab Waste) } \\
\end{array}$ & Vitrification & $\begin{array}{l}\text { Storage and } \\
\text { Evaporation }\end{array}$ & Yes & Interface Stream 10 (See Table 11-8) \\
\hline $\begin{array}{l}\text { Recovered } \\
\text { Organic }\end{array}$ & Vitrification & CIF & $\overline{\text { Yes }}$ & Interface Stream II (See Table 11-8) \\
\hline $\begin{array}{l}\text { Recovered } \\
\text { Mercury }\end{array}$ & Vitrification & $\begin{array}{l}\text { Mercury } \\
\text { Receivers }\end{array}$ & Yes & Interfuce Stream 12 (See Table 11-8) \\
\hline
\end{tabular}


Table 11-6: Effluent Treatment Facility (ETF) Interfaces

\begin{tabular}{|c|c|c|c|c|}
\hline Stream & From & To & $\begin{array}{l}\text { Within Scope } \\
\text { Of PID? }\end{array}$ & Basis for Control \\
\hline $\begin{array}{l}\text { Generic } \\
\text { Streams (See } \\
\text { Table 11-1) }\end{array}$ & Any generator & & & See Table 11-1 \\
\hline $\begin{array}{l}\text { Evaporator } \\
\text { Overheads } \\
\text { And Other } \\
\text { Low-Level } \\
\text { Streams }\end{array}$ & $\begin{array}{l}\text { Storage and } \\
\text { Evaporation, } \\
\text { F \& H } \\
\text { Canyons, And } \\
\text { Other } \\
\text { Facilities }\end{array}$ & ETF & Yes & Interface Stream 13 (See Table 11-8) \\
\hline $\begin{array}{l}\text { Diverted } \\
\text { Stormwater }\end{array}$ & $\begin{array}{l}\text { Storage and } \\
\text { Evaporation, } \\
\text { ITP, ESP }\end{array}$ & ETF́ Basins & Yes & Interface Stream 17 (See Table 11-8) \\
\hline $\begin{array}{l}\text { Diverted } \\
\text { Cooling Water }\end{array}$ & $\begin{array}{l}\mathrm{F} \& \mathrm{H} \\
\text { Canyons } \\
\end{array}$ & ETF Brsins & Yes & Interface Stream 18 (See Table 11-8) \\
\hline $\begin{array}{l}\text { Treated Water } \\
\text { Effluent }\end{array}$ & ETF & ETF Outfall & No & Interface Stream 14 (See Table 11-8) \\
\hline $\begin{array}{l}\text { ETF } \\
\text { Concentrate }\end{array}$ & ETF & Tank 50H & Yes & Interface Stream 15 (See Table 11-8) \\
\hline $\begin{array}{l}\text { Clean } \\
\text { Discharges } \\
\text { From Basins }\end{array}$ & ETF Basins & ETF Outfall & No & $\begin{array}{l}\text { ETF Internal Procedures } \\
\text { ETF Wastewater Permits } \# 14218 \text { And } 14219 \\
\text { Chemical constituents controlled by NPDES Permit SCO000175 } \\
\text { Radioactive components controlled by DOE } 5400.5\end{array}$ \\
\hline $\begin{array}{l}\text { Highly } \\
\text { Contaminated } \\
\text { Cooling Water } \\
\text { Or Storm } \\
\text { Water }\end{array}$ & ETF Basins & $\begin{array}{l}\text { Storage and } \\
\text { Evaporation }\end{array}$ & Yes & Interface Stream 19 (See Table 11-8) \\
\hline $\begin{array}{l}\text { Highly } \\
\text { Contaminated } \\
\text { ETF } \\
\text { Concentrate } \\
\end{array}$ & $\begin{array}{l}\text { ETF } \\
\text { Treatment } \\
\text { Plant }\end{array}$ & $\begin{array}{l}\text { Storage and } \\
\text { Evaporation }\end{array}$ & Yes & Interface Stream 20 (See Table 11-8) \\
\hline
\end{tabular}


Table 11-7: DWPF Saltstone Interfaces

\begin{tabular}{|c|c|c|c|c|}
\hline Stream & From & To & $\begin{array}{l}\text { Within Scope } \\
\text { Of PID? }\end{array}$ & Basis for Control \\
\hline $\begin{array}{l}\text { Generic } \\
\text { Streams (See } \\
\text { Table 11-1) }\end{array}$ & Any generstor & & & See Table 11-1 \\
\hline Saltstone Feed & $\begin{array}{l}\text { In-Tank } \\
\text { Precipitation } \\
\text { (Tank 5OH) }\end{array}$ & Saltstone & Yes & Interface Stream 6 (See Table 11-8) \\
\hline $\begin{array}{l}\text { Wet Grout To } \\
\text { Landfill }\end{array}$ & Saltstone & Landfill & No & Interface Stream 16 (See Table 11-8) \\
\hline
\end{tabular}


Table 11-8: Interfaces Within The Scope Of The Process Interface Description

Ext $=$ External Interface To The HLW System

Int $=$ Internal Interface To The HLW System

$\mathrm{CC}=$ Contamination Control Interface

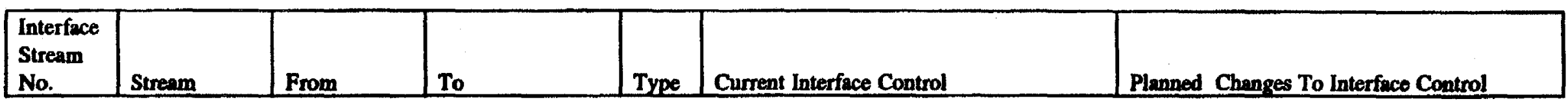

\begin{tabular}{|c|c|c|c|c|c|c|}
\hline 1 & $\begin{array}{l}\text { Incoming } \\
\text { Wastes }\end{array}$ & $\begin{array}{l}\text { All } \\
\text { Geaerntors }\end{array}$ & $\begin{array}{l}\text { Storage and } \\
\text { Evaporation }\end{array}$ & Ext & $\begin{array}{l}\text { Receiver Controls: } \\
\text { HLW Waste Acceptance Criteria } \\
\text { Special streams reviewed case-by-case by } \\
\text { HLWE } \\
\text { Sender Controls: } \\
\text { Tickler requires quarterly meetings } \\
\text { between HLWE Support Group and } \\
\text { generators sending waste to Tank Farms. }\end{array}$ & $\begin{array}{l}\text { Add: } \\
\text { Sender Control: Waste Compliance Plan for } \\
\text { each generator, including Waste Management } \\
\text { Maintenance Facility (299-H) }\end{array}$ \\
\hline 2 & Sludge & $\begin{array}{l}\text { Storage and } \\
\text { Evaporation }\end{array}$ & ESP & Int & $\begin{array}{l}\text { Sender Control: High-Level Waste } \\
\text { System Plan }\end{array}$ & $\begin{array}{l}\text { Add: } \\
\text { Receiver Controls: } \\
\text { ESP Process Requirements } \\
\text { Estimates of batch-by-batch composition by } \\
\text { the Material Evaluation Board }\end{array}$ \\
\hline 3 & $\begin{array}{l}\text { ESP Spent } \\
\text { Washwiter }\end{array}$ & $\mathbf{E S P}$ & $\begin{array}{l}\text { Storage and } \\
\text { Evaporation }\end{array}$ & Int & $\begin{array}{l}\text { Sender Control: } \\
\text { Tank Farm Trunsfer Procedure, 241-FH- } \\
\text { TTQ }\end{array}$ & $\begin{array}{l}\text { No change planned. No formal receiver } \\
\text { control is needed for this stream because } \\
\text { the washwater is diluted tank farm supermate. } \\
\text { The only concern is inhibition, which is } \\
\text { adequately controlled by the existing } \\
\text { procedure. }\end{array}$ \\
\hline 4 & $\begin{array}{l}\text { Washed } \\
\text { Sludge }\end{array}$ & ESP & $\begin{array}{l}\text { DWPF } \\
\text { Vitrification }\end{array}$ & Int & $\begin{array}{l}\text { Receiver Controls: } \\
\text { DWPF Feed Design Bases Document }\end{array}$ & $\begin{array}{l}\text { Add Sender Control: } \\
\text { ESP PRs }\end{array}$ \\
\hline 5 & Salt Solution & $\begin{array}{l}\text { Storage and } \\
\text { Evaporation }\end{array}$ & $\begin{array}{l}\text { In-Tank } \\
\text { Precipitation }\end{array}$ & Int & $\begin{array}{l}\text { Receiver Controls: } \\
\text { ITP SAR } \\
\text { ITP Process Requirements } \\
\text { Sender Controls: } \\
\text { High-Level Waste System Plan }\end{array}$ & $\begin{array}{l}\text { Add receiver control: } \\
\text { Estimates of batch-by-batch compositions by } \\
\text { Material Evaluation Board }\end{array}$ \\
\hline
\end{tabular}


High-Level Waste System Process Interface Description

\begin{tabular}{|l|l|l|l|l|l|l|}
\hline $\begin{array}{l}\text { Interface } \\
\text { Stream } \\
\text { No. }\end{array}$ & Stream & From & To & Type & Current Interface Control & Planned Changes To Interface Control \\
\hline
\end{tabular}

\begin{tabular}{|c|c|c|c|c|c|c|}
\hline 6 & $\begin{array}{l}\text { Saltstone } \\
\text { Feed }\end{array}$ & $\begin{array}{l}\text { ITP } \\
\text { (Tank 50H) }\end{array}$ & Saltstone & Int & $\begin{array}{l}\text { Receiver Controls: } \\
\text { Saltstone Waste Acceptance Criteria } \\
\text { Sender Controls: ITP Process } \\
\text { Requirements }\end{array}$ & Add Saltstone Waste Acceptance Criteria \\
\hline 7 & $\begin{array}{l}\text { Partially } \\
\text { Washed } \\
\text { Precipitate }\end{array}$ & $\begin{array}{l}\text { In-Tank } \\
\text { Precipitation }\end{array}$ & $\begin{array}{l}\text { Vitrification (Late } \\
\text { Wash \& DWPF) }\end{array}$ & Int & $\begin{array}{l}\text { Receiver Controls: } \\
\text { DWPF Feed Design Bases Document } \\
\text { Sender Control: } \\
\text { ITP Process Requirements }\end{array}$ & : \\
\hline 8 & $\begin{array}{l}\text { Late Wash } \\
\text { Spent } \\
\text { Washwater }\end{array}$ & $\begin{array}{l}\text { DWPF } \\
\text { Vitrification } \\
\text { (Late Wash) }\end{array}$ & $\begin{array}{l}\text { In-Tank } \\
\text { Precipitation }\end{array}$ & Int & $\begin{array}{l}\text { Receiver Control: } \\
\text { HLW WAC } \\
\text { Sender Control: } \\
\text { None } \\
\end{array}$ & $\begin{array}{l}\text { Sender Control: } \\
\text { Develop a Late Wash Waste Compliance Plan }\end{array}$ \\
\hline 9 & $\begin{array}{l}\text { Canistered } \\
\text { Glass Waste } \\
\text { Form }\end{array}$ & $\begin{array}{l}\text { DWPF } \\
\text { Vitrification }\end{array}$ & Repository & Ext & $\begin{array}{l}\text { Receiver Controls: } \\
\text { DOE Waste Acceptance Product } \\
\quad \text { Specifications } \\
\text { Sender Controls: } \\
\text { Wasteform Compliance Plan } \\
\text { Waste Acceptance Reference Manual }\end{array}$ & No Change \\
\hline 10 & $\begin{array}{l}\text { DWPF } \\
\text { Recycle }\end{array}$ & $\begin{array}{l}\text { DWPF } \\
\text { Vitrificution }\end{array}$ & $\begin{array}{l}\text { Storage and } \\
\text { Evaporation }\end{array}$ & Int & $\begin{array}{l}\text { Roceiver Control: HLW Waste } \\
\text { Acceptance Criteria } \\
\text { Sender Controls: } \\
\text { None (PRs are existing but plans are to } \\
\text { replace them) }\end{array}$ & $\begin{array}{l}\text { Sender Control: DWPF Waste Compliance } \\
\text { Play }\end{array}$ \\
\hline 11 & $\begin{array}{l}\text { Recovered } \\
\text { Organic }\end{array}$ & $\begin{array}{l}\text { DWPF } \\
\text { Vitrification }\end{array}$ & $\begin{array}{l}\text { Consolidated } \\
\text { Incineration } \\
\text { Facility (CIF) }\end{array}$ & Ext & $\begin{array}{l}\text { No receiver criteria are currently } \\
\text { available. }\end{array}$ & $\begin{array}{l}\text { Receiver Control: } \\
\text { CIF Waste Acceptance Criteria } \\
\text { Sender Control: } \\
\text { DWPF Waste Compliance Plan }\end{array}$ \\
\hline 12 & $\begin{array}{l}\text { Recovered } \\
\text { Mercury }\end{array}$ & $\begin{array}{l}\text { DWPF } \\
\text { Vitrification }\end{array}$ & $\begin{array}{l}\text { Mercury } \\
\text { Receivers }\end{array}$ & $\overline{E x t}$ & No approved controls at this time & \\
\hline
\end{tabular}




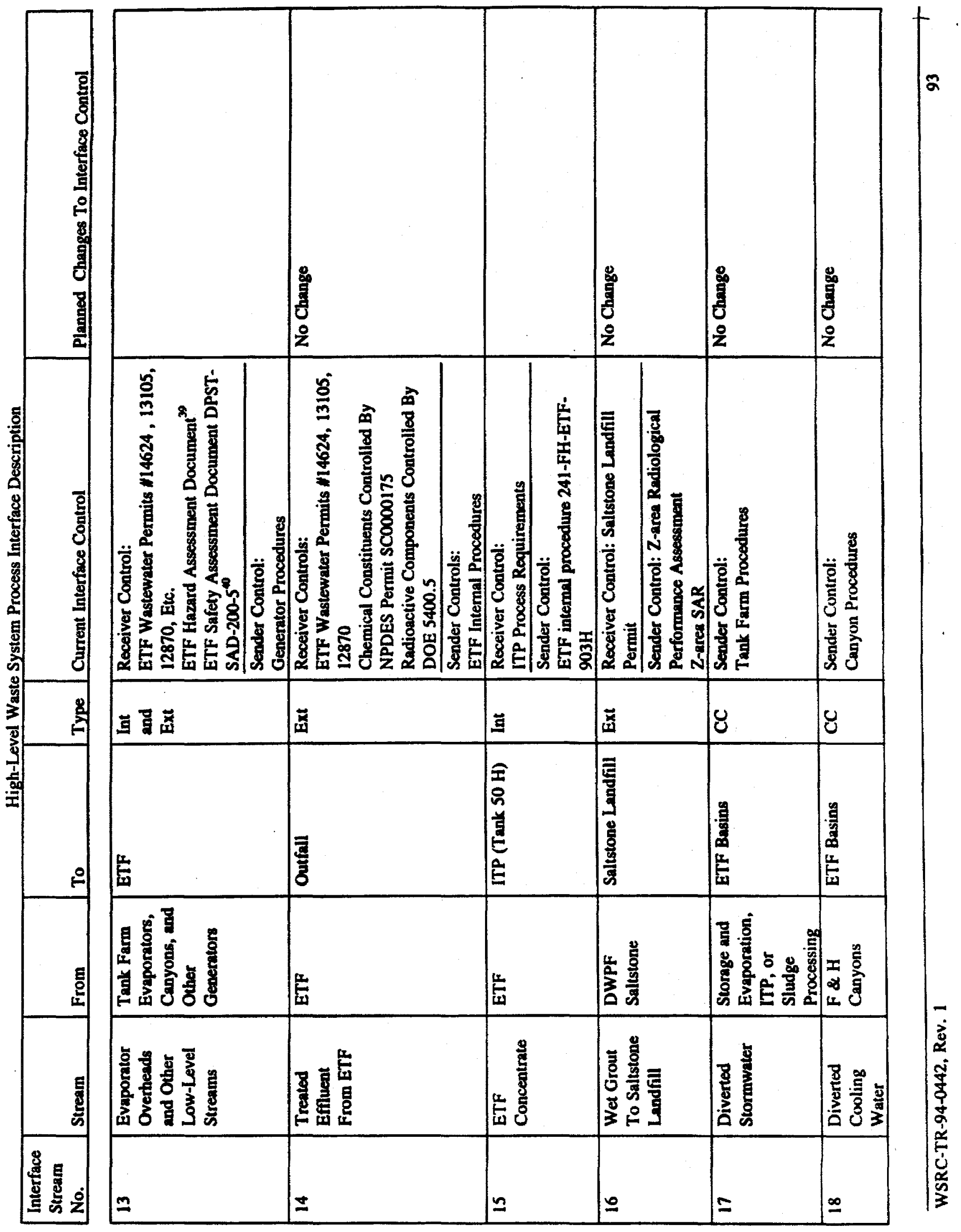


High-Level Waste System Process Interface Description

\begin{tabular}{|l|l|l|l|l|l|l|}
\hline $\begin{array}{l}\text { Interface } \\
\text { Stream } \\
\text { No. }\end{array}$ & Stream & From & To & Type & Current Interface Control & Planned Changes To Interface Control \\
\hline
\end{tabular}

\begin{tabular}{|l|l|l|l|l|l|l|}
\hline 19 & $\begin{array}{l}\text { Highly } \\
\text { Contaminated } \\
\text { Cooling } \\
\text { Water Or } \\
\text { Storm Water }\end{array}$ & ETF Basins & $\begin{array}{l}\text { Storage and } \\
\text { Evaporation } \\
\text { (Via HDB-8) }\end{array}$ & CC & $\begin{array}{l}\text { Roceiver Control: } \\
\text { HLW Waste Acceptance Criteria }\end{array}$ & $\begin{array}{l}\text { No Change } \\
\text { Sender and Receiver Control: } \\
\text { Reviewed case-by-case by HLWE }\end{array}$ \\
\hline 20 & $\begin{array}{l}\text { Highly } \\
\text { Contaminated } \\
\text { ETF } \\
\text { Concentrate }\end{array}$ & $\begin{array}{l}\text { ETF } \\
\text { Treatment } \\
\text { Plant }\end{array}$ & $\begin{array}{l}\text { Storage and } \\
\text { Evaporation } \\
\text { (Via HDB-8) }\end{array}$ & CC & $\begin{array}{l}\text { Receiver Control: } \\
\text { HLW Waste Acceptance Criteria }\end{array}$ & $\begin{array}{l}\text { Sender and Receiver Control: } \\
\text { Reviewed case-by-case by HLWE }\end{array}$ \\
\hline
\end{tabular}




\section{DEFINITIONS AND ACRONYMS}

CERCLA-Comprebensive Environmental Response, Compensation, and Liability Act of 1980 The Act under which the high-level waste tanks will be closed. The Federal Facility Agreement is a CERCLA document.

CIF-Consolidated Incineration Facility An incinerator fucility now under construction in $\mathbf{H}$ area. The incinerator will be used to dispose of recovered organic from the DWPF in addition to many other incinerable streams at SRS.

\section{DOE-(The United States) Department of Enersy}

DWPF-Defense Waste Procescing Facility The HLW process in which partially washod precipitate and washed sludge are converted iato a borosilicate glass in a canistered glass wasteform. See Chapter 8.

EPA-(The United States) Environmental Protection Agency

ESP-Extended Sludge Processing The HIW process in which the insoluble sludges are washed and in which some sludges are treated to remove aluminum compounds. See Chapter 7.

ETF-Efnuent Treatment Facility The HLW process that decontaminates low-level wastewaters so that they can be released to the environment. See Chapter 9.

F area One of the processing areas at the SRS. The F-area Tank Farm, which is one part of the Storage and Evaporation Process, is in F area. See Chapter 5.

Federal Repository A geologic repository being developed by the Federal government for storage of highly radioactive wasten, primarily the DOE high-level wautes and speat nuclear fuel from commercial power reactors. Once the Federal Repository is constructed and started up, plans are to send the Canistered Glass Wasteform to the repository for final disposal.

FFA-Federal Facility Agreement A comprehensive document signed by EPA, SCDHEC, and DOE describing how CERCLA waste sites at SRS will be managed. The FFA bes a section on the Tank Farms that describes how the Tank Farm will be regulated, sets forth secondary containmeat criterit for bigh-level waste tanks, and establishes a regulatory process for closure of the waste tanks under CERCLA.

H area One of the processing areas at SRS. The H-area Tunk Farm-which includes ITP, ESP, and the H-area part of the Storage and Evaponation Process-is located in H area. See Chapters 5,6, and 7.

High-Level Waste Process One of six processes that comprise the high-level waste system. The six HLW Proceseces are

1) High-Level Waste Storage and Evaporation (F-and H-area Tank Farma)

2) Salt Proceseing (In-Tank Precipitation)

3) Extended Sludge Procewing

4) Vitrification (DWPF Late Wash, Pretreatment, and Vitrification)

5) Wastewater Treatment (Effluent Treatmeat Facility)

6) Solidification (DWPF Saltstone)

Figh-Level Waste System The set of six HLW Processen, interconnocted by pipelines, that treat high-level wastes received in F and H areas at the SRS. Together, theee six HLW Proceseses function as one large treatment plant that treats high-level wastes and converts them into forms suitable for final disposal. 
High-Level Waste System Plan A document that describes the overall plan for removing the wastes from Storage and Evaporation and proceasing this waste through the HLW System.

HLW-High-Level Waste "The highly radioactive waste material that results from the reprocessing of spent nuclear fuel, including liquid waste produced directly in reprocessing and any solid waste derived from the liquid, that contains a combination of transuranic waste and fission products in concentrations requiring permanent isolation." (DOE order 5820.2A) Most of the wastes received into the Tank Farms are High-Level Wastes.

FLWM-High-Level Waste Management Division The WSRC Division charged with operating the HLW System.

HLW Material Evaluation Board A board established by the HLWM division Chief Engineer to estimate the composition of batches of waste to be sent to the DWPF.

HLW Storage and Evaporation Proceas (F- \& H-area) Those processing areas in the F-and H-Area Tank Farms dedicated to safe and environmentally sound storage of High-Level Waste. Within the H-area Tank Farm are tanks dedicated to other purposes, specifically In-Tank Precipitation and Extended Sludge Processing. See section 5.1.2.

ICD(ICDs)-Interface Control Document(s) A document(s) describing the method of controlling the interface between two HLW Processes or between a HLW Process and an external process.

Interface $A$ boundary in the HLW system through which wastes are exchanged between HLW Processes or between a HLW Process and an external process.

ITP--In-Tank Precipitation The HLW Process in which supernate is decontaminated. See Chapter 6.

LWF-Late Wash Facility One of the DWPF processes, in which the partially washed precipitate from ITP is fully washed before being sent to the DWPF Vitrification building. See Chapter 8.

PID-(High-Level Waste System) Process Interface Description A document describing the entire HLW System in terms of its mission. The document treats the entire HLW System as one large process, and identifies the tochnical bases for regulating the interfaces between the HLW Processes to ensure that changes with broed impact are adequately communicated, reviewed, and controlled.

RCRA-Resource Conservation and Recovery Act An Act that regulates the opention of hazardous waste facilities and other aspects of high-level waste management. The only facility in the HLW System that is regulated by this law is Tank 16H, which is the subject of a RCRA facility investigation.

S area The proceesing area at SRS that contains the DWPF Vitrification building (221-S).

Salt (Saltcake) The soluble salts in high-level waste. Salt plus water comprises supernate. When the supernate is concentrated in an evaporator and sent to a waste tank, the salts precipitate because of their high concentration and form a light-colored crystalline saltcake.

SCDHEC-South Carolina Department of Health and Environmental Control The regulatory agency that has primary environmental authority over the HLW System.

SIMP-System Integration Management Plan A HLWM division guidance that describes how the PID, the High-Level Waste System Plan, and the High-Level Waste Integrated Flowsheet Model are used and modified, and how these documents work together to control the HLW system. 
High-Level Wate Syatem Proces Interfice Deccription

Sludge The insoluble compounds produced when Sepantions waste, which is highly acidic, is neutralized with sodium hydroxide. Thene insoluble compounds settle to the bottom of tanks in the Tenk Farms and form a dark brown phase called sludge.

SRS-Savannah River Site

Supernate In a waste receipt trak, the clear salt solution remaining in the top of the tank after the insoluble sludges or salts have settled to the bottom. Also used to refer to any clear liquid in a waste tank, including salt receipt tanks and evaporator foed tanks.

Storage and Evaporation Sec "HLW Slorage and Evaporation"

Tank Farms (F- and H-area) Those proceseing areas at SRS that contain the high-level waste traks. The F-area Tank Farm contains part of the Storage and Evaporation Procees. The H-area Tank Farm contains ITP, ESP, and the rest of the Storage and Evaporation Process.

Technical Baseline For a particular HLW Process, the Technical Baseline is all documents, including all safety documentation, used to identify, justify, and demonatrate the physical, functional, or operational requirements of structure, systems, and components (WSRC E7, Procedure 1.02). The Interfece Control Documents as defined in the PID are part of the technical baseline for each HLW Process.

TOST-(HLW) Technical Orersight Stearing Team A team chrired by the HLWM Division Chief Engincer and composed of the HLW Engineering Level 3 menagers and DOE HLW Managemeat. The team is responsible for overseeing all of the technical activities in the HLWM division, which includo changes to the PID, the High-Level Waste System Plan, the SIMP, the Technology Program Plan, and the HighLevel Waste Integnated Flowshed Model.

USQD-Unreviewed Sofety Question Determination A process for determining if a Unreviowed Safety Question exists for a particularly sctivity or condition, and whether DOE approval is required for implemeating the change.

WAC Waste Acceptance Criteria An ICD written by the receiving organization deacribing the parameters (e.g. composition, flow, tempernture) that must be considered in receiving the waste and defining criteris for acceptance of the waste.

WAPS (DWPF) Waste Acceptance Product Specifications-A DOE document describing the requirements for the Canistered Glass Wastoform to be accepted into the Federal Repository

WCP-Waste Compliance Pian An ICD written by the seoding organization deacribing how the sending organization will ensure that it is in compliasce with the WAC of the receiving organization.

WSRC-Weatinghouse Saranuh River Company The primary contractor for operation of SRS.

$\mathrm{Z}$ area The processing area at SRS that contains the Saltstone procese. See Chapter 10. 


\section{REFERENCES}

1. W. L. Poe, "Leakage from Waste Tank 16; Amount, Fate, and Impact," DP-1358, November 1974

2. Code of Federal Regulations, Title 40, Part 264, "TSD Facility Standards, " Subpart J, "Tank Systems," 264.193, "Contrinment and detection of releases"

3. EPA, SCDHEC, and DOE, "Federal Facility Agreement under section 120 of CERCLA and 3008(h) and 6001 of RCRA," EPA Administrative Docket Number 89-05-FF, Effective August 16, 1993

4. EPA and DOE, "Federal Facility Compliance Agreement," EPA Administrative Docket Number 91-01-FFR, EPA ID Number SC1 890008 989, Effective 3/13/91

5. H. D. Harmon, "High-Level Waste Management Technology Program Plan, " HLW-TEC-940020, Rev. 0, 31 October 1994

6. High-Level Waste System Plan, Rev. 4, HLW-OVP-94-0415, 30 November 1994

7. "As-Built Construction Permit Application for an Industrial Waste Treatment Facility for the F-and H-area High-Level Radioactive Waste Tank Farms," Rev. 0, April 1991

8. "Waste Acceptance Criteria for High-Lovel Liquid Waste Transfers to the 241-F/H Tank Farms," X-SC-G00001, Rev. 1, March 1995

9. A. S. Barab, "Discontinuing Transfer of Silver Compounds to 242 Waste Tanks," (Unnumbered document) 30 September 1970

10. P. D. d'Entremont, "High-Level Waste Characterization in Support of Low Level Waste Certification: Chapter VI--Physical/Chemical Characterization of Solid Waste Generated in High Level Waste Facilities," WSRC-TR-94-0393, Revision 1, 19 August 1994

11. M. Hawkins, "Listed Waste in HL Tanks Background Information," ESH-FSG-90007, 7 February 1990

12. J. S. Roberts, "Listed Waste From Laboratories-Tiger Team Finding WM/BMP-6, " ESH-FSG-900315, 29 May 1990

13. "Acceptance Criteria for Aqueous Waste Seat to the Saltstone Production Facility in Z-area," DRAFT procedure 3.14 in 15 Manual

14. N. D. Hutson and R. A. Jacobe, "DWPF Feed Design Basee," WSRC-TR-93-0133, Rev. 0, March 9, 1993

15. "Safety Analysis Report, Savannah River Site, Liquid Radioactive Waste Handling Facilities, Addendum 1, Additional Analysis for DWPF Feed Preparation by In-Tank Processing," WSRC-SA-15, Rev 6, December 1994

16. "DWPF Waste Form Compliance Plan," WSRC-IM-91-116-0, Rev. 2, June 1993

17. J. P. Ryan and R. E. Stimson, "Technical Data Summary, F/H Effluent Facility," DPSTD-84-114, December 1984

18. "Operational Safety Requirements, 241-82H Control Room," WSRC-RP-94-303, Revision 2, 15 December 1994

19. "Process Requirements, 241-82H Control Room," WSRC-IM-91-63, Revision 3, November 1994

20. "Safety Analysis--200 Area, Liquid Radioactive Waste Handling Facilities," DPSTSA-200-10, Sup-18, August 1988

21. "Technical Standards, Waste Tank Farms," DPSTS-241-3.01, May 15, 1988

22. M. C. Chandler, "HLW Criticality Safety Program Plan," Rev. O, HLW-HLE-94-0385, February 22, 1994 
23. WSRC-RP-94-112, "ESP Washwater Disposal Options," L. O. Dworjanyn, January 25, 1994

24. "DWPF Late Wash Facility," WSRC-RP-92-793, Rev. 3, February 1994

25. DWPF Air Emission Permit, 0080-0066-CA, South Carolina Department of Health and Environmental Control

26. DOE Office of Environmental Restoration and Waste Management, "Waste Acceptance Product Specifications for Vitrified High-Level Waste Forms," Rev. O, Feb 1993

27. "Waste Form Qualification Report," WSRC-IM-91-116-X $X=$ volume number)

28. Waste Acceptence Reference Manual, WSRC-IM-93-45

29. DWPF Recycle Waste Compliance Plan, to be developed

30. HLW-OVP-95-0010, Revision 0, "High-Level Waste Managemeat System Integration Management Plan,"

31. SCDHEC Wastewater Permits 14624, 13105, 12870, and 14020.

32. SCDHEC Wastewater Permit SCO000175

33. DOE Order 5400.5, "Radiation Protection of the Public and the Environment"

34. "Safety Analysis Z-Area Savannah River Site Saltstone Facility," WSRC-SA-3, DOE Review Draft, September 1992.

35. J. R. Fowler, "Justification for Continued Operation of the SRS Saltstone Facility (Z-Area), "WSRC-RP-92444, March 31, 1992.

36. Test Authorization, "Transfer of Salt Solution from Tank 50H to Saltstone," WSRC-OX-89-15-001 (Rev. 5)

37. C.A. Langton and D.G. Thompson, "Conceptual Z-Ares Cap and Second Generation Vault Design (u)," WSRC-RP-90-992, Westinghouse Savannah River Company, Savannah River Laboratory, Aiken, SC (October 12, 1990).

38. J. R. Fowler et al., "Radiological Performance Assessment for the Z-Area Saltstone Disposal Facility," WSRC-RP-92-1360 (Rev. 0), December 18, 1992.

39. ETF Hazurd Assessment Document, WSRC-TR-93-031, Rev. 1

40. ETF Safety Assessment Document, DPST-SAD-200-5 